\title{
1983 Annual Report on Alaska's Mineral Resources
}

GEOLOGICAL SURVEY CIRCULAR 908

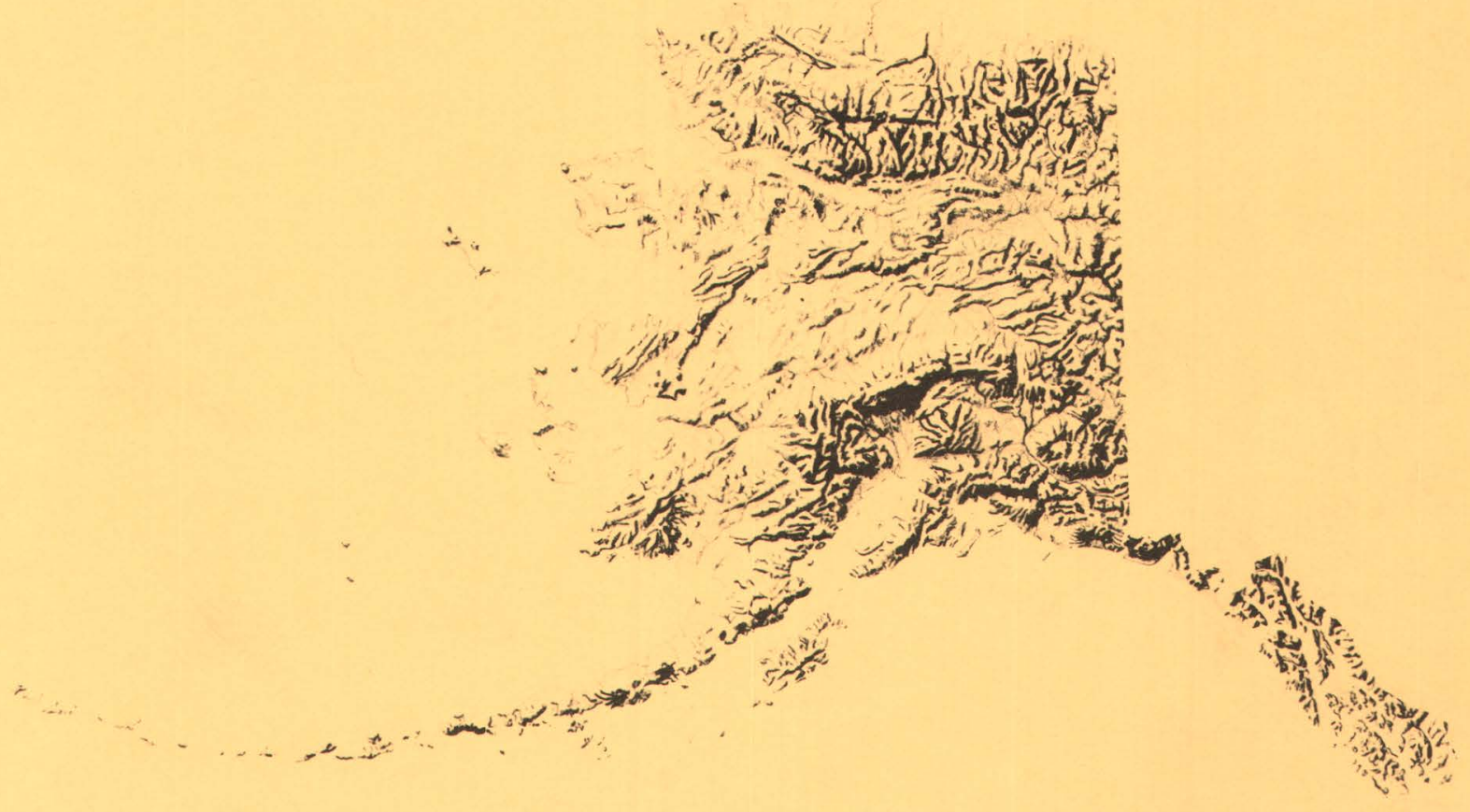

Prepared in cooperation with the Bureau of Mines, the Bureau of Land Management, the National Park Service, the U.S. Fish and Wildlife Service, the Minerals Management Service, the Department of Agriculture-Forest Service, and the Department of Energy As mandated by Section 1011 of the Alaska National Interest Lands Conservation Act, Public Law 96-487, of December 2, 1980 
Contributors to the report:

Kenneth Bird, U.S. Geological Survey James Callahan, Bureau of Land Management David Carnes, Bureau of Mines Fred Chiei, Department of Energy John Cook, National Park Service Kendell Dickinson, U.S. Geological Survey Fred Harnisch, Forest Service Linda Harris, U.S. Geological Survey (illustrator) Don Hinrichsen, Bureau of Land Management Thomas Miller, U.S. Geological Survey John Mulligan, Bureau of Mines Katherine Reed, U.S. Geological Survey (editor) Wayne Roberts, Department of Energy Keith Schreiner, U.S. Fish and Wildlife Service Richard Stenmark, National Park Service Gary Stricker, U.S. Geological Survey Gary Winkler, U.S. Geological Survey 


\section{Annual Report on}

\section{Alaska's Mineral Resources}

GEOLOGICAL SURVEY CIRCULAR 908

Prepared in cooperation with the Bureav of Mines, the Bureau of Land Management, the National Park Service, the U.S. Fish and Wildlife Service, the Minerals Management Service, the Department of Agriculture-Forest Service, and the Department of Energy As mandated by Section 1011 of the Alaska National Interest Lands Conservation Act, Public Law 96-487, of December 2, 1980 
United States Department of the Interior

JAMES G. WATT, Secretary

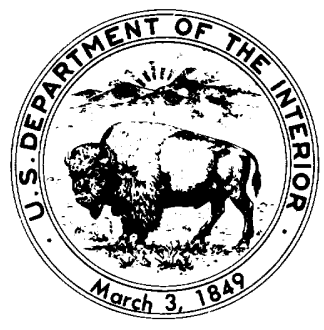

Geological Survey

Dallas L. Peck, Director 


\section{CONTENTS}

Executive summary

Oil and gas

Coal and peat

Uranium

Geothermal energy

Nonfuel minerals

Critical and strategic minerals

Introduction

Department of the Interior

U.S. Geological Survey

Bureau of Mines

Bureau of Land Management --_-_-_-_-_--_--

Minerals Management Service-_-_._-____-__-_._-

National Park Service---_--_-_-_-_-_-_-_-_-_--

U.S. Fish and Wildlife Service-

Department of Agriculture-Forest Service-

Department of Energy

Contacts for further information

Oil and gas -

Activity by Federal agencies in 1982

Industry activity in 1982

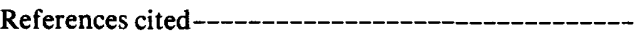

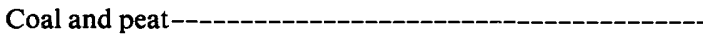

Activity by Federal agencies in 1982

State studies of coal in 1982

Cooperative State-Federal studies of peat resources in 1982
1

1

2

2

2

3

3

4

4

6

7

8

8

10

10

11

11

12

13

18

19

19

19
State studies of peat in 1982

Industry activity in 1982 --_-_-_-_-_-_-_-_ 21

References cited-_-_-_-_-_-_ 22

Uranium-_-_-_-_-_-_-_-_-_-_-_-_-_-_-_-_-_-_-_-_-- 22

Activity by Federal agencies in $1982-[-12$

Industy activity in 1982-_- 22

Geothermal resources --_-_-_-_-_-_-_-_-_-_-_ 23

Activity by Federal agencies in 1982 -_._-_-_-_-_ 23

State studies in 1982 -_-_-_ 23

Nonfuel minerals--_-_-_-_-_-_-_-_-_-_-_-_-_-_-_ 23

Activity by Federal agencies in 1982 --_-_-_-_-_ 26

Industry activity in 1982

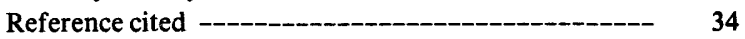

Critical and strategic minerals --_-_-_-_- 34

Activity by Federal agencies in 1982 -_- 34

Industry activity in 1982--_-_-- 35

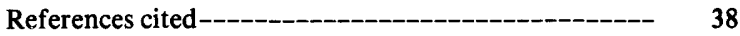

Selected references -

U.S. Geological Survey-_-_-_- 39

Bureau of Mines --_-_-_-_-_-_-_-_-_-_-_ 44

U.S. Fish and Wildlife Service-_-_-_-_-_-_-_-_ 44

Bureau of Land Management -_-_-_-_-_-_-_-_ 45

National Park Service-_-_-_-_-_-_-_-_-_-_-_ 45

Department of Agriculture-Forest Service---_--_--- 45

Department of Energy ---_-_-_-_-_ 45

Miscellaneous Federal publications-_-_-_-_-_-_-_-- 46

Non-Federal publications-_-_-_-_-_-_-_-_-_-_ 46

\section{ILLUSTRATIONS}

FIGURES 1-10. Maps showing:

1. Distribution of National Interest Lands and conservation units established by the Alaska National Interest Lands Conservation Act of 1980

2. Areas scheduled for analysis prior to uplands oil and gas leasing by the Bureau of Land Management

3. Favorable Petroleum Geological Provinces, areas offered for lease, Arctic National Wildlife Refuge study area, proposed gas pipeline route, and public land unit

4. Location of exploratory wells drilled in 1982, oil and gas fields, and Alaskan onshore and nearshore sedimentary basins

5. Areas of Federal, State, and industry activity for coal, peat, uranium, and geothermal energy resources

6. Locations of areas studied by the U.S. Geological Survey and the Bureau of Mines for nonfuel, critical, and strategic minerals

7. Status of Level III Alaska Mineral Resource Assessment Program studies, January 1, 1983-_-_-_-_ 


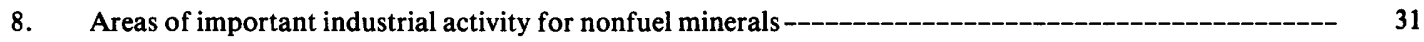

9. Areas of Bureau of Mines' investigations for critical and strategic minerals in 1982-_- 36

10. Areas of industrial activity for critical and strategic minerals

\section{TABLES}

TABLE $1 A$. Onshore oil and gas lease status, 1982

1B. Federal noncompetitive offerings, 1982

2. Onshore exploratory test wells, 1982

3. Value of minerals produced in Alaska -

4. Abbreviated titles or brief descriptions of projects whose study areas are shown in figure 6---_-

5. Areas of industry activity for nonfuel minerals

6. Locality and prospect names, to accompany figure 9

7. Localities of interst for critical and strategic minerals, to accompany figure 10

7. Localities of interst for critical and strategic minerals, to accompany figure 10 


\section{Annual Report on Alaska's Mineral Resources, As Mandated by Section 1011 of the Alaska National Interest Lands Conservation Act, Public Law 96-487, of December 2, 1980}

Prepared by the U.S. Geological Survey, in cooperation with the Bureau of Mines, the Bureau of Land Management, the National Park Service, the U.S. Fish and Wildlife Service, the Minerals Management Service, the Department of Agriculture-Forest Service, and the Department of

Energy

\section{EXECUTIVE SUMMARY}

Section 1011 of the Alaska National Interest Lands Conservation Act (ANILCA) of 1980 requires that "On or before October 1, 1982, and annually thereafter, the President shall transmit to the Congress all pertinent public information relating to minerals in Alaska gathered by the United States Geological Survey, Bureau of Mines, and any other Federal agency." This report has been prepared in response to that requirement.

The Geological Survey and the Bureau of Mines are the principal Federal agencies that publish information about mineral resources in Alaska. Their information is commonly used by other Federal agencies in making decisions about access, land use, environmental impacts, or claim evaluations. The greater part of the information in this report therefore has come from the Survey and the Bureau. Because of the time required for sample analysis and data synthesis and for the publication process, reports are generally issued a year or more after the sample and data collection.

This is the second of the annual ANILCA reports. It provides information about projects current in 1982. Articles in trade and professional journals, symposia proceedings, talks at public meetings and hearings, press releases, and newspaper and magazine articles, as well Federal and State publications, have been the sources of the information presented.

The report addresses onshore areas of Alaska only. It provides information on minerals of current in- terest in two broad categories: energy resources and nonfuel, critical, and strategic minerals.

\section{OIL AND GAS}

The State of Alaska ranked second among oilproducing States during 1982. The two petroleumproducing areas, the North Slope and Cook Inlet, both on State lands, provided a total of 619 million barrels of oil and 191 billion cubic feet of natural gas. These totals represent an increase of about 5 percent over 1981 totals. Alaska now provides about 20 percent of United States oil production.

Industry onshore exploration and development activity in the State during 1982 proceeded at nearly the same levels as in 1981. State and Federal agencies continued to carry out their designated regulatory functions and conducted lease sales and surveys relating to land classification and oil and gas resource evaluation.

Exploration activity included geological and geophysical surveys and drilling of 13 exploratory wells12 on State or Native lands on the North Slope and 1 on State land in the Cook Inlet basin. Development activity included drilling of about 200 production wells in the Prudhoe Bay and Kuparuk fields and the initiation of enhanced oil recovery projects in both fields. Plans were submitted for the Endicott Development project; this is a new field, just offshore of the Prudhoe Bay field, in which production could 
begin as early as 1988. Also initiated in 1982 were studies of possible production methods for an accumulation of 18 to 40 billion barrels of heavy oil in shallow reservoirs just west of the Prudhoe Bay field.

The State of Alaska held four competitive oil and gas lease sales in 1982, and three Federal lease sales also took place. Companies and groups of investors bid a total of about $\$ 104$ million for 1.5 million acres of land at these events. In addition, the State opened a total of about 3.2 million acres in the Minchumina and Denali-Tiekel areas to noncompetitive leasing.

The proposed Alaska Natural Gas Transportation System pipeline, intended to tap North Slope gas, remains stalemated by financial problems.

Federal agencies continued to be active in the $\mathrm{Na}$ tional Petroleum Reserve in Alaska in 1982. The Bureau of Land Management and the Minerals Management Service were involved in tract selection and tract evaluation. The Bureau held two competitive lease sales in the Reserve in 1982 and has scheduled another sale for 1983. The Geological Survey released numerous contractor reports resulting from its exploration program, which ended in 1981. The Survey is preparing approximately 30 reports about the Reserve by agency scientists for publication in 1983 or 1984 . The Survey also is negotiating the transfer of control of the Barrow gas field to North Slope Native organizations.

Elsewhere in Alaska, Federal agencies were active in oil and gas programs as required by the ANILCA. The Bureau of Land Management and the Geological Survey continued their studies of oil and gas resources, wilderness characteristics, and wildlife resources in the area between the National Petroleum Reserve in Alaska and the Arctic National Wildlife Range, north of latitude $68^{\circ} \mathrm{N}$. The Bureau of Land Management and the Fish and Wildlife Service carried on their systematic analysis of land south of latitude $68^{\circ} \mathrm{N}$ for mineral leasing, including oil and gas. The Fish and Wildlife Service and the Geological Survey completed a draft environmental impact statement for surface geological and geophysical exploration of the coastal plain of the Arctic National Wildlife Range.

\section{COAL AND PEAT}

Of the major coal fields in Alaska, only the BelugaCapps Glacier, Nenana, and Bering River fields are currently being studied for future development. The Geological Survey has been making engineering studies of the Beluga area for some years. Two companies have drilled more than 200 holes in this field and are presently studying international markets for the coal.

The State's only active mine is in the Nenana field. Mine owners have agreed to sell about 800,000 tons of coal annually to a Korean shipping company and a possible additional amount to a Korean power company. Another Korean consortium of companies, in concert with an Alaskan Native corporation, is conducting feasibility studies for development in the Bering River field.

The State continues its interest in the extensive peat deposits in south-central Alaska as a potential energy source. As many as $\mathbf{3 0}$ million acres there may contain commercially harvestable peat; the State has contracted for feasibility studies of harvesting methods.

\section{URANIUM}

Because of low demand and prices, large uranium supplies, and high costs of logistics in exploration in Alaska, uranium work by industry is at a near standstill. The Department of Energy has completed the data-collection phase of its National Uranium Resource Evaluation program and is now releasing the results of that work. The Geological Survey examined uranium-bearing sedimentary rocks in southeastern Alaska, near Cordova, and in an area east of Nome; none of the deposits studied appears to have commercial potential at this time.

\section{GEOTHERMAL ENERGY}

Widespread volcanic activity in Alaska suggests a large potential for geothermal energy. Presently, much of this energy appears to be suitable mainly for local use.

The Geological Survey continued studies of centers of volcanic activity on the Alaska Peninsula. The State of Alaska has contracted for drilling on Unalaska Island in search of steam or hot-water reservoirs. In addition, the State received applications for geothermal exploration in the Mt. Spurr area, west of Anchorage; the State's first geothermal lease sale, involving 10,240 acres, was scheduled for May 17, 1983. Drilling under contract to another State agency has confirmed the presence of a shallow geothermal reservoir at Pilgrim Springs on the Seward Peninsula. 


\section{NONFUEL MINERALS}

The potential for development of Alaska's nonfuel mineral resources was in the public focus repeatedly during 1982. Professional societies, trade and advocacy groups, and Federal and State agencies sponsored meetings, published documents, and lobbied legislatures about the promise of mineral resource development in the State. Although the dollar value of total mineral production statewide increased about 4 percent, expenditures for exploration for new deposits in 1982 decreased by an estimated 50 percent and in 1983 may be reduced by as much as 40 percent more, reflecting the worldwide economic slump. Two Alaska-based exploration offices were closed during the past year.

The number of gold operations in Alaska appears to have stabilized. However, the total production continued to increase-probably due to more efficient mining and milling techniques. Presently, the dollar value of gold production accounts for 60 percent of Alaskan mineral production when sand and gravel are excluded.

Expenditures for feasibility studies or predevelopment activities increased by more than 50 percent at the molybdenum deposit at Quartz Hill near Ketchikan, at the silver and base-metals deposit at Greens Creek near Juneau, and at the lead-zinc deposit at Red Dog in the western Brooks Range in 1982. Such corporate expenditures are expected to increase again in 1983. Greens Creek and Quartz Hill are presently on schedule for projected commencement of operations in the late 1980's.

Native regional corporations have increased their emphasis on mineral resource potential when selecting their remaining land entitlements, and exploration activities have been widespread on the 44 million acres that have been or are being conveyed to these corporations. Several Native corporations have entered into contracts, joint ventures, or other arrangements to gain mineral exploration and development expertise.

Alaska State agencies, such as the Departments of Commerce and Economic Development, Transportation and Public Facilities, and Natural Resources, have adopted advocacy roles in the development of mineral resources in Alaska by promoting risk capital incentives, creation of additional transportation infrastructure, and publication of scientific studies of several productive mining districts.

The U.S. Geological Survey, through its Alaska
Minerals Resource Assessment Program, continued multidisciplinary studies in $161: 250,000$-scale quadrangles in the Brooks Range, the Seward Peninsula, the Yukon-Tanana Uplands, the Alaska Range, the Alaska Peninsula, and southeastern Alaska. Twenty-four quadrangles have already been completed. A Roadless Area Resource Evaluation and wilderness study program, being carried on jointly by the Geological Survey and the Bureau of Mines in the Prince William Sound and Kenai Peninsula areas of the Chugach National Forest, is nearing completion. Final reports for joint Geological Survey-Bureau of Mines mineral resources assessment studies in the National Petroleum Reserve in Alaska and for the West Chichagof-Yakobi Wilderness study area in the Tongass National Forest in southeastern Alaska were issued in 1982. The Bureau of Mines continues its mineral lands assessment and mineral availability programs throughout the State. Assessments were completed in 1982 for nonfuel mineral occurrences in western Prince William Sound, the western Brooks Range, and Yakobi Island.

\section{CRITICAL AND STRATEGIC MINERALS}

There was continuing emphasis by industry and Government in 1982 on advertising Alaska's significant potential resources of chromium, cobalt, nickel, platinum-group minerals, and tin, but less emphasis on active exploration than in the previous several years. One Alaska-based strategic minerals exploration office was closed during the year. Only platinum and tin continued to be produced at approximately the same levels as in 1981. The State of Alaska sponsored a marketing feasibility study of chromium, cobalt, nickel, and platinum-group metals and produced an inventory of strategic mineral occurrences in the State.

The U.S. Geological Survey continued its study of chromium, cobalt, nickel, and platinum-group elements associated with igneous ultramafic rocks and of tin associated with igneous granitoid rocks in the western interior of the State. The Bureau of Mines continued to evaluate occurrences of critical and strategic minerals throughout Alaska; the results of their investigations in the western Brooks Range and central Alaska were published during the year. A joint Geological Survey-Bureau of Mines resource assessment of the West Chichagof-Yakobi Wilderness study area, which contains significant resources of nickel and cobalt, also was completed. 


\section{Annual Report on Alaska's Mineral Resources, As Mandated by Section 1011 of the Alaska National Interest Lands Conservation Act, Public Law 96-487, of December 2, 1980}

Prepared by the U.S. Geological Survey, in cooperation with the Bureau of Mines, the Bureau of Land Management, the National Park Service, the U.S. Fish and Wildlife Service, the Minerals Management Service, the Department of Agriculture-Forest Service, and the Department of Energy

\section{INTRODUCTION}

Section 1011 of the Alaska National Interest Lands Conservation Act (ANILCA) of 1980 requires that "On or before October 1, 1982, and annually thereafter, the President shall transmit to the Congress all pertinent public information relating to minerals in Alaska gathered by the United States Geological Survey, Bureau of Mines, and any other Federal agency." This Circular has been prepared in response to that requirement under the lead of the Geological Survey, which has been delegated that responsibility.

This report considers only onshore Alaskan areas. No information about Outer Continental Shelf or maritime areas is given, although such information may have been used in studies of mineral occurrences. In keeping with the mandate for "pertinent public information," this report describes recently released material about commodities or mineral groupings rather than presenting a region-by-region synopsis of mineral-related activity in Alaska.

The Geological Survey and the Bureau of Mines are the primary Federal agencies generating information about mineral resources in Alaska. Their information is used by other Federal agencies as the basic input for decisions about access, land use, environmental impacts, and, in some instances, claim evaluation. The greater part of the information in this Circular has come from studies, projects, or programs conducted by the Survey and the Bureau. Additional input has been obtained from the Alaska Division of Geological and Geophysical Surveys.

The term "public information" as applied in this Circular includes the published results of Federal projects and studies, either in Government reports or in professional and trade journals. Other sources include talks by Government representatives or persons with private companies at symposia and conferences or their proceedings volumes, press releases, newspaper and magazine articles, and other public forums. The result of publication procedures of the Federal agencies that regularly publish their findings is that interpretive information usually appears in the literature a year or more after sample and data collection and analysis. For this reason, this Circular chiefly consists of material that was made public in 1982. A similar lag will affect all Section 1011 annual reports for ANILCA. Information about active projects also is included in this Circular.

The minerals discussed in this annual report fall into two broad categories about which the report has been structured-namely, energy resources (oil and gas, uranium, coal and peat, and geothermal resources) and nonfuel, critical, and strategic minerals. Construction materials, such as sand and gravel, are not discussed here.

The following pages describe the roles of land management and other Federal agencies as they relate to mineral information and activities. The distribution of ANILCA conservation units managed by Federal agencies is shown in figure 1 .

\section{DEPARTMENT OF THE INTERIOR}

\section{U.S. GEOLOGICAL SURVEY}

The U.S. Geological Survey was established to conduct systematic scientific investigations of the 


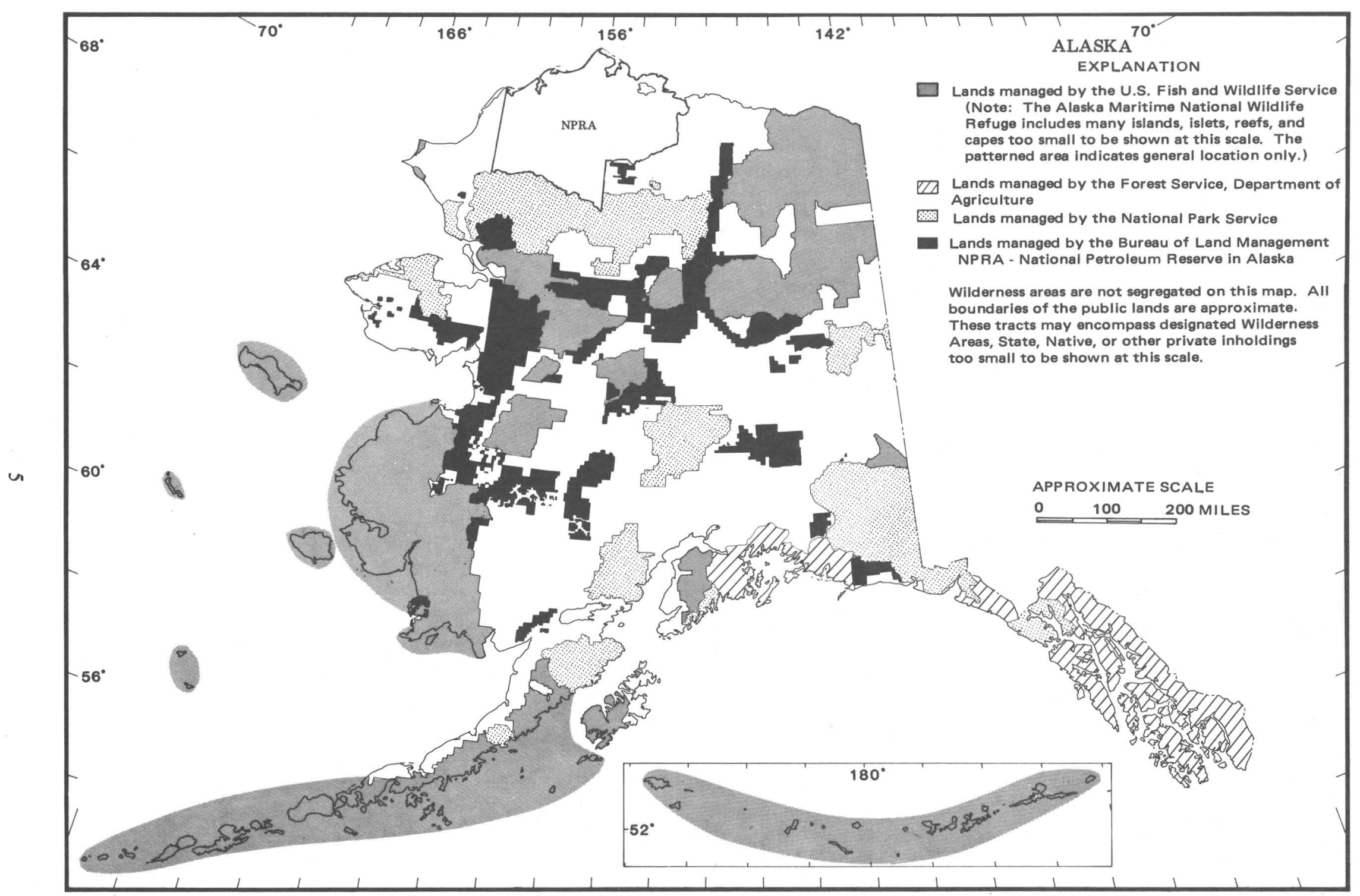

FIGURE 1.-Distribution of National Interest Lands and conservation units established by the Alaska National Interest Lands Conservation Act of 1980 . Boundaries as of January 1983. 
geologic structure and mineral resources of the $\mathrm{Na}$ tion. The Survey carries out its mission through topographic mapping; geologic, geochemical, and geophysical studies; stream measurements; geohazards research; application of remote-sensing techniques; and participation in multidisciplinary and interdepartmental projects and studies. [The Survey's regulatory, leasing, and accounting functions were taken over by the Minerals Management Service, established in January 1982.]

In recent years, the Survey's role in assessing mineral resources has increased, particularly in the area of energy resources. Numerous field and research projects gather information about domestic petroleum, coal, uranium, and geothermal resources. Further, national legislation requires that mineral assessments be made of areas to be set aside as wilderness and areas to be addressed under ANILCA. The Alaska Mineral Resource Assessment Program (AMRAP, described more fully in the nonfuel minerals section of this Circular), for example, has as its goal a systematic investigation of the State's resources. This program, which began in 1975, is involved with these assessments and consists of four progressively more detailed levels of study of portions of the State. Studies in Level III draw on many geologic disciplines to produce areal resource assessments, many as $1: 250,000$-scale quadrangle maps; 25 such studies have been finished or are nearing completion. More than 20 Level IV studies of individual mining districts, mineral deposits, or other topics related to mineral formation are underway. The products of such studies are used to help determine our national mineral and energy endowment and to analyze potential hazards and impacts. They also help industry locate and develop mineral supplies and assist in developing concepts, models, and techniques to identify strategic and critical mineral deposits. Survey publications are a common source of basic data about mineral deposits of interest to industry.

Other Geological Survey programs also were active in Alaska in 1982. Among these were (1) the North Slope Petroleum Program, which consisted of six regional basin analysis studies; (2) the Arctic Environmental Studies Program, which has investigated transportation corridors and other areas of development to obtain baseline geotechnical data and to observe and record conditions along the oil pipeline route so as to relate these conditions to geologic characteristics of the areas; (3) the Earthquake Hazards Program, part of nationwide research into prediction, induced seismicity, and hazards assessments; (4) the Volcanic Hazards Program, concerned with assessing hazards and predicting eruptions; (5) the Geothermal Research Program, a multidisciplinary program whose goal is understanding the nature, distribution, and energy potential of the Nation's geothermal resources; (6) the Geologic Synthesis and Framework Program, designed to acquire baseline information, particularly on Alaskan tectonic settings and intrusive igneous rocks, from which to develop regional syntheses; and (7) the Climate Change Program, which seeks to understand the reasons for the mechanisms of climate changes. Projects under each of these programs are described in Geological Survey Circular 867.

The Survey frequently cooperates with other Federal and State agencies in topical or regional studies, such as AMRAP and the programs briefly described above. In addition, it is often the lead agency in preparing environmental impact statements for areas where mineral activity is proposed.

The Geological Survey's Branch of Alaskan Geology has its headquarters in Anchorage and a field office in Fairbanks. Other branch geologists are stationed in Menlo Park, Calif. Seismic observatories are maintained in Alaska in Fairbanks, Adak, Barrow, and Sitka.

\section{BUREAU OF MINES}

Briefly stated, the Bureau's mission is to help assure that the Nation's mineral supplies are adequate to maintain national security, economic growth, and employment. The Bureau of Mines is represented in Alaska by the Field Operations Center with headquarters in Juneau and offices in Anchorage and Fairbanks. The Alaska Field Operations Center carries out the mission in five program areas:

(1) Minerals availability-This program in Alaska is part of a worldwide Bureau of Mines program that relies on two computerized data bases, the Minerals Industry Location System (MILS) and the Minerals Availability System (MAS). MILS contains basic information about mineral deposits coded for inclusion in the MILS data bank. For deposits with sufficient reserves, a MAS evaluation is made to estimate the quantity and quality of the mineral commodities, the engineering and beneficiation technologies for extraction and recovery, the capital and operating costs, and the institutional constraints. Data are obtained from private industry and from the Bureau's mineral assessment and critical and strategic minerals 
programs. A complex computer and communication system allows the mineral information to be stored, manipulated, and retrieved. Data are retrieved as computerplotted maps or as printouts of MAS and MILS data. These data enable the Bureau of Mines to develop and continually update estimates of the mineral commodities available to industry nationally and worldwide.

(2) Land assessment-One of the Bureau of Mines' major programs in Alaska is the evaluation of the mineral potential of Federal lands to aid Congress and the land-managing agencies in land management decisions. Currently under investigation are more than 5.6 million acres in Chugach National Forest in south-central Alaska. Work there started in 1979; final reports are scheduled for 1983. This is a Roadless Area Resource Evaluation (RARE II) wilderness study carried on jointly with the U.S. Geological Survey. The Geological Survey maps the geologic features and makes geophysical and geochemical reconnaissances to delineate mineralized areas. The Bureau of Mines samples and maps the minerals occurrences in these areas to estimate their potential value under anticipated conditions. The ultimate objective of the mineral land assessment program is to identify the mineral deposits and mineralized areas in Alaska that contain a significant part of the Nation's mineral supplies.

(3) Critical and strategic minerals-This statewide program supplements the mineral land assessment program. Emphasis has been on cobalt, chromite, and the platinum-group metals, but work has started on tin; eventually other commodities may be included. Deposits on Federal lands closed to mineral entry by industry are investigated, as are deposits on lands open to entry if they are not of current interest to private industry. Cooperative efforts with industry also have been undertaken. In addition to locating deposits and estimating size and grade, bulk samples are taken for metallurgical research to estimate recoverability and costs. These investigations should create a stockpile in the ground that can be used when needed.

(4) Mining research-Mining research is directly related to the mineral land assessment and the critical and strategic minerals programs. Various Bureau of Mines and university research centers cooperate with the Alaska Field Operations Center to solve mineral utilization problems. The Bureau has a continuing metallurgical research program concerned with critical and strategic minerals. Current studies are focused on potential chromium-bearing materials in southcentral Alaska and on potential cobalt, nickel, and platinum-group metals in southeastern Alaska. A cooperative program with the University of Alaska is concerned with underground placer mining methods. The Bureau of Mines and the University of Alaska have for many years participated in maintenance and use of a permafrost research center at Fox, near Fairbanks, in cooperation with the Corps of Engineers Cold Regions Research and Engineering Laboratory.

(5) State Minerals Specialist-The State Minerals Specialist cooperates with the Bureau's commodity experts in Washington, D.C., and with the State of Alaska's Division of Geological and Geophysical Surveys to collect and verify data about mineral activities and mineral production for periodic and annual reports, including the Minerals Yearbook. This office is a principal point of contact with the minerals industry, Federal and State agencies, and the general public.

\section{BUREAU OF LAND MANAGEMENT}

The Bureau of Land Management is responsible for multiple-use management of the surface and subsurface of 23 million acres of the National Petroleum Reserve in Alaska (NPRA), 400,000 acres of the Central Arctic Management Area, and approximately 115 million acres of public lands south of Alaska's North Slope (fig. 1); the last figure includes substantial acreage encumbered through State and Native selections. Additionally, the Bureau of Land Management administers geothermal resources and leasable and locatable minerals on other Federal lands, including acquired lands, and on private lands where the Federal Government has retained mineral rights.

In December 1982, the Bureau of Land Management issued a mineral resources policy statement that reflects the Bureau's continuing commitment to encourage private enterprise in the development of the 
domestic minerals consistent with the need for these resources. Public lands are generally to remain open to environmentally sound mineral exploration and development. Land-use planning will reflect energy and mineral values through geologic assessments. To reinforce the Bureau's mineral resource policy, the Secretary of Interior, in December 1982, merged onshore energy and mineral functions of the Minerals Management Service into the Bureau of Land Management. A significant restructuring of the National, State, and district offices is underway, the result of which will be a strong minerals orientation. The reorganization proposes offices for fluid minerals (oil and gas and geothermal resources; resource evaluations), for solid minerals (coal, oil shale, tar sand, and nonenergy leasable minerals), and mining law and mineral assessment. Department review of the proposals was scheduled for February and March 1983.

The Bureau of Land Management's administrative responsibilities for minerals require close coordination with other surface management agencies. Generally, in the case of upland leases, the Bureau of Land Management issues leases and integrates the leasing with other land uses in cooperation with the surface management agency. After a lease is issued, the newly integrated minerals function assumes jurisdiction of exploratory and developmental activities in cooperation with the land manager to assure surface protection. Figure 2 describes areas tentatively scheduled for analysis to determine which lands not on the North Slope should be opened to mineral leasing.

The principal activities of the Bureau of Land Management that are related to Alaska's minerals and energy resources are (1) preparation for the scheduling of Federal oil and gas leases in the upland areas with the concurrence of the surface management agency, (2) conducting and evaluating Federal oil and gas lease sales, and (3) recordation of mining claims and determinations of the validity of mining claims for mineral patents. In the past, the Bureau of Land Management has rarely produced reports that pertain to the evaluation of mineral and energy resources; with the Minerals Management Service (onshore) merger, the Bureau of Land Management will be producing reports pertaining to public land mineral potential.

The Bureau of Land Management is responsible for enforcing the environmental and technical stipulations attached to the Agreement and Grant of Right of Way for the Trans-Alaska Pipeline System. The overall goal is to maintain a continuous supply of energy with minimum environmental impact. The
Bureau also is charged with issuing land-use authorization and mineral and material sales to support preconstruction activities for the planned natural gas pipeline.

\section{MINERALS MANAGEMENT SERVICE}

The primary functions of the Minerals Management Service are to examine and classify Federal Outer Continental Shelf (OCS) lands as to their mineral resources, to determine estimated petroleum values for offshore competitive lease sales, to supervise exploration and development of such leases, and to maintain accounts and collect royalties and rents of petroleum, coal, and certain other mineral commodities such as potash. The Minerals Management Service, established in 1982, has taken over some of the functions of the former Conservation Division of the Geological Survey and is responsible to the Assistant Secretary for Energy and Minerals. Its Alaskan headquarters are in Anchorage.

The Minerals Management Service's regulations and procedures are subject to frequent review and appraisal, to avoid or mitigate the consequences of pollution incidents, surface damage, or other potential hazards that may be associated with operations conducted under leases and prospecting permits.

The Minerals Management Service prepares background material for leases, well in advance of the lease sale date, in coordination with the Bureau of Land Management, the Geological Survey, and other Federal and State agencies. The Service is also involved in the preparation of environmental impact statements for proposed lease areas. Further, the Minerals Management Service refines resource estimates for each area to be leased by using geological and geophysical information and identifies hazards to exploration and production in these areas. For each lease tract, it arrives at a value that is used as a basis for accepting or rejecting bids received during the lease sales. The Service then becomes responsible for collection of and accounting for the money due the Federal Government from oil and gas produced and for rents and royalties.

Functions of the Minerals Management Service pertaining to onshore resources are being transferred to the Bureau of Land Management.

\section{NATIONAL PARK SERVICE}

National Park Service management of lands in the Federal park system is directed “**** to conserve the scenery and natural and historic objects and the 


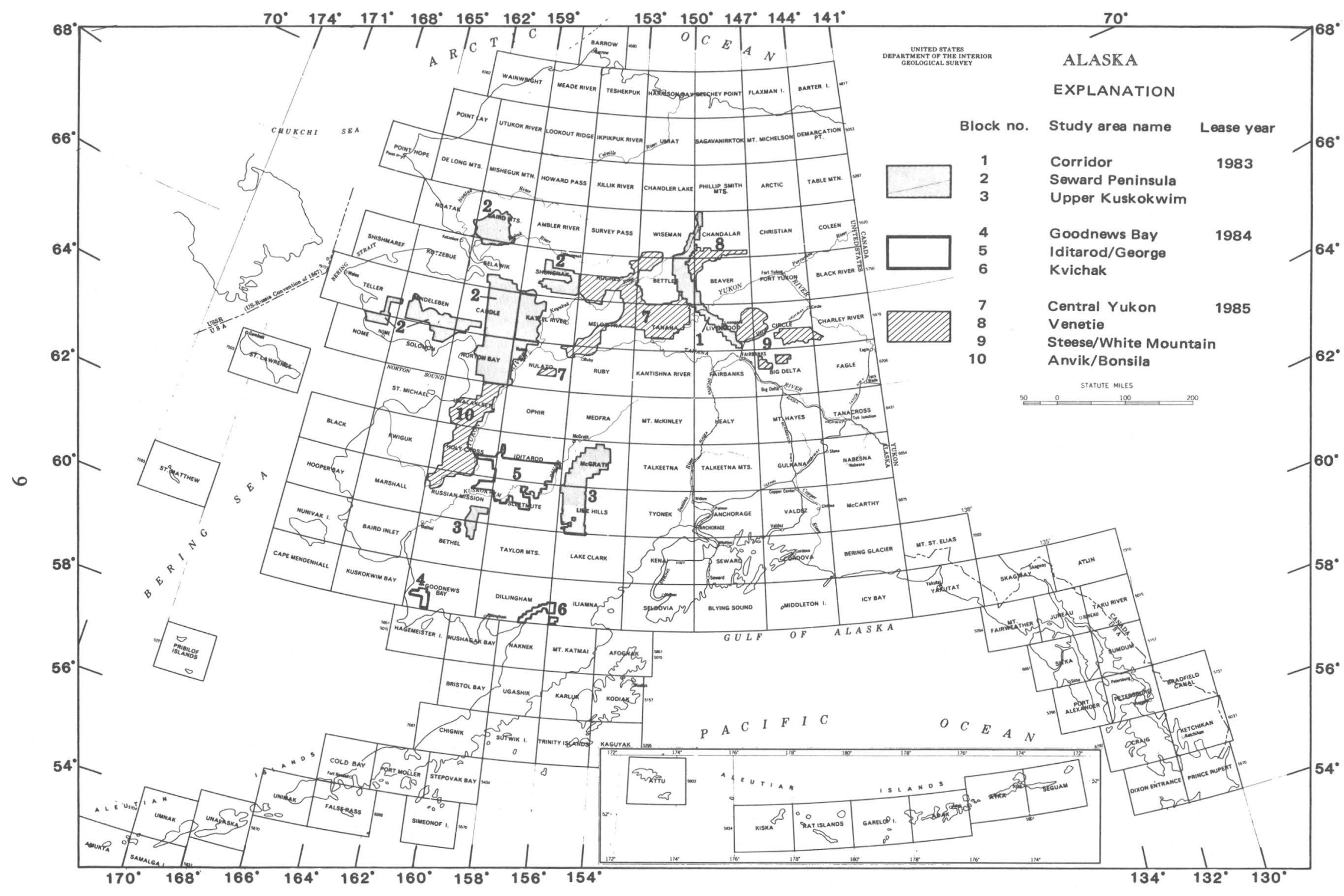

FIGURE 2.-Areas scheduled for analysis prior to uplands oil and gas leasing by the Bureau of Land Management. 
wildlife $* * *$ and to provide for enjoyment of the same in such a manner and by such means as will leave them unimpaired for the enjoyment of future generations." Administrative policy is based on the principles of maintenance of the natural resources and on the concept that national interest dictates decisions affecting private or public enterprise in the parks. The Service currently has jurisdiction over an estimated 52 million acres of park lands in Alaska (fig. 1). Its main Alaskan office is in Anchorage.

Park Service responsibility for mining claims and mining on park lands in Alaska and elsewhere is basically limited to mineral examinations and determinations of valid existing rights, environmental assessments of the natural and cultural resources and potential impacts of mining on Federal or other lands, protection of park resources through mining plans developed under Federal regulations, and approval of mining plans of operation. The assessments and mining plans are available for public review.

Except for validity determinations, the Service rarely collects or publishes basic data about mineral deposits, commonly relying on information gathered by claimants, the Geological Survey, the Bureau of Mines, or State or private sources. Validity determinations also involve the Bureau of Land Management and the Office of Appeals and Hearings. Results of mineral examinations are made public when final decisions are made.

\section{U.S. FISH AND WILDLIFE SERVICE}

The national mission of the Fish and Wildlife Service is to provide the Federal leadership to conserve, protect, and enhance fish and wildlife and their habitats for the continuing benefit of people.

In Alaska, the Service seeks to accomplish this mission through a variety of programs that implement the provisions of the Endangered Species Act, Marine Mammals Protection Act, Fish and Wildlife Coordination Act, River and Harbors Act, National Wildlife Refuge System Administration Act, various migratory bird laws, and other statutes. Direct activities under these laws include administration of 76 million acres of National Wildlife Refuges, fish and wildlife research, law enforcement, and review and comment on permit requests and environmental impact statements.

Under the provisions of ANILCA, 16 refuges (fig. 1) were created or enlarged to conserve fish and wildlife populations and their habitats, as well as other

'From the act establishing the Park Service, approved August 25, 1916 (39 Stat 535). values. Except for valid rights existing at the time of establishment, these refuges are closed to entry, location, and patent under mining laws. The refuges are open to entry under the mineral leasing laws.

While many traditional values have been deemed appropriate for these areas, other uses, including oil and gas leasing, will be permitted when such activities are compatible with the purposes for which the refuges were established. The compatible uses will be determined through the Comprehensive Conservation Planning process currently underway for these refuges. Except as required in the Conservation Plans and in the baseline study on the Arctic Coastal Plain, the Fish and Wildlife Service does little mineral assessment work.

\section{DEPARTMENT OF AGRICULTURE-FOREST SERVICE}

The mission of the Forest Service, Department of Agriculture, is to provide a continuing flow of natural resource goods and services to help meet national needs and to contribute to meeting such needs worldwide. The Forest Service encourages management of its lands for multiple use to provide a sustained flow of renewable resources. To do this, it assesses and analyzes present and anticipated needs, supplies, and uses for resources in public and private forests and rangeland; makes these resources fully productive; encourages and assists private landowners through State organizations to improve, protect, and use forest resources; develops and distributes information about technology; and directs programs of resource conservation. The Forest Service is developing management plans for both of Alaska's National Forests, Tongass and Chugach, which together encompass about 23 million acres (fig. 1).

The Forest Service also administers nonrenewable resources to help meet the Nation's need for mineral and energy resources by accommodating exploration and development on Federal lands under their jurisdiction, consistent with other values of the lands. It provides research information and technology to help with postmining reclamation. In cooperation with the Bureau of Land Management, Forest Service geologists check the validity of claims in trespass cases, patent requests, and claims planned for development in withdrawn areas of the National Forest system. The report is sent to the Bureau of Land Management with recommendations, and that agency makes final decisions about the claims' validity.

Certain lands administered by the Forest Service may be withdrawn from appropriation and entry (in- 
cluding that under mining laws) and reserved for public purposes. An environmental assessment is prepared by the Forest Service for all proposed withdrawals. The assessment includes a minerals report developed in coordination with the Bureau of Mines, Bureau of Land Management, U.S. Geological Survey, and other agencies. The announcement of the proposed withdrawal is placed in the Federal Register, and time is allowed for public comments. Final decisions about withdrawal by the Bureau of Land Management are published in the Federal Register.

The Forest Service maintains its Alaska regional office in Juneau. The Chugach Forest headquarters are in Anchorage; offices for the Tongass Forest are in Juneau, Sitka, Ketchikan, and Petersburg.

\section{DEPARTMENT OF ENERGY}

The functions of the Department are primarily in the areas of (1) administering the current petroleum acts and Congressional mandates relating to energy, (2) monitoring grants, and (3) overseeing contracts for studies of geothermal and uranium energy resources described in later sections of this report. The Department has a field office in Anchorage.

The Department's National Uranium Resource Evaluation (NURE) program was initiated in 1974 to estimate the domestic uranium resources in the 48 conterminous States and Alaska. Projects of national scope, the Airborne Radiometric and Magnetic Surveys (ARMS) and the Hydrogeochemical and Stream Sediment Reconnaissance Survey (HSSR), and geologic topical studies of regional or provincial scope were conducted to define geologic environments favorable for uranium deposition. These assessments were carried on in areas including those of uranium production, known ore reserves, and estimated potential resources. Components of the NURE program active in Alaska have consisted of ARMS, HSSR, geologic map compilation, quadrangle evaluation, and topical and regional studies. The data collection phase of the program is now complete, and the agency is releasing reports based on that effort. The 1982 releases are listed under the Department's heading at the back of this Circular.

\section{CONTACTS FOR FURTHER INFORMATION}

For more information about Federal programs or projects concerned with mineral or energy resources of Alaska, please contact the following:

Department of the Interior

Bureau of Land
Management

Bureau of Mines

U.S. Fish and
Wildlife Service U.S. Geological
Survey

Minerals Management Service ${ }^{2}$

National Park

Service

\author{
George Gurr \\ Public Affairs Office \\ or \\ Joseph Jones, Deputy State \\ Director \\ Division of Energy and \\ Minerals \\ Federal Building \\ 701 C Street \\ Anchorage, AK 99513
}

John Mulligan, Chief Alaska Field Operations Center

P.O. Box 550

Juneau, AK 99802
Keither Schreiner, Regional Director

1011 East Tudor Road

Anchorage, AK 99503
Thomas Miller, Chief Branch of Alaskan Geology 4200 University Drive Anchorage, AK 99508-4667

The Service's office is at 800 A Street Anchorage, AK 99501

\section{Roger Contor, Regional \\ Director \\ Alaska Area Office \\ 540 West 5th Avenue \\ Anchorage, AK 99501}

\section{Department of Agriculture}

Forest Service

$$
\begin{aligned}
& \text { Norman Day, Mineral } \\
& \text { Examiner } \\
& \text { Alaska Region } \\
& \text { P.O. Box } 1628 \\
& \text { Juneau, AK } 99802 \\
& \text { [Staff officers in Sitka, } \\
& \text { Ketchikan, Anchorage, and } \\
& \text { Petersburg also may be } \\
& \text { contacted.] }
\end{aligned}
$$

\footnotetext{
${ }^{2}$ Some functions of the Minerals Management Service are being transferred to the Bureau of Land Management. For information about onshore mineral activities, contact the Bureau of Land Management of fices listed.
} 


\author{
Department of \\ Energy
}

Fred Chiei, Regional

Representative

Federal Building

701 C Street

Anchorage, AK 99513

\section{OIL AND GAS}

In 1982, as in the previous several years, petroleum (oil and gas) was the most valuable resource produced in Alaska. During 1982, Alaska's two petroleumproducing areas, Arctic North Slope and Cook Inlet, provided a total of 619 million (42-gallon) barrels of oil and 191 billion cubic feet of natural gas, an increase of about 5 percent over 1981 (Alaska Oil and Gas Conservation Commission Bulletin, 1983, listed with references cited at the end of this section). Production increases on the State of Alaska's North Slope leases more than offset production declines from Cook Inlet, so that the daily rate of oil production at the end of 1982 amounted to 1.68 million barrels or about 20 percent of the United States daily production (Oil and Gas Journal, 1982, v. 81, p. 85).

During 1982, Federal and State agencies conducted seven onshore competitive oil and gas lease sales, opened two areas totaling $3,246,139$ acres to noncompetitive oil and gas leasing, monitored and supervised lease development, collected rentals on leases and royalties on production, and conducted numerous geologic and geophysical studies relating to oil and gas resource evaluation and land classification. These studies are only briefly reported in this document; the reader is directed to U.S. Geological Survey Circular 867 (Reed, 1982, listed at the back of this report) and the State of Alaska quarterly report, "Alaska Mines and Geology" (released in October 1982), for details.

At competitive lease sales, a total of $\$ 104$ million was offered in high bids to acquire about 1.5 million acres of land for future exploration. Information about the lease sales and offerings is summarized in table $1 A$ and $1 B$, and the lease areas are shown in figure 3. The terms of the State leases can be obtained from the Lease Administration Office, Alaska Department of Natural Resources, 555 Cordova Street, Anchorage, AK 99501.

Industry activity in onshore Alaska in 1982 included geophysical and geological surveys and the drilling of 13 exploratory wells (table 2 and fig. 4) and about 200 development wells in the two operating fields. Development drilling was concentrated on the North Slope in the Prudhoe Bay and Kuparuk oil fields, where enhanced recovery programs also were initiated.

Exxon Company USA, Sohio Alaska Petroleum Company, and partners submitted plans for Government approval for the development of a new field, Sag Delta-Duck Island, just east of Prudhoe Bay. In addition, studies of possible production methods were undertaken by ARCO Alaska, Inc., for a vast accumulation of heavy oil in shallow reservoirs just west of the Prudhoe Bay field.

State and Native land selections have significantly affected future sales of areas having known petroleum potential; that is, the lands within any of the three Favorable Petroleum Geological Provinces (FPGP) and in the Central Arctic Management Area (CAMA). Virtually all of the Cape Lisburne area FPGP is in the process of conveyance to the State of Alaska or to private entities. Review of lands in the Gulf of Alaska Tertiary and Cook Inlet Tertiary FPGP's is underway to determine lands not under State or Alaska Native Claim Settlement Act (ANCSA) selection that may be acceptable for sale. The majority are lands under the jurisdiction of the U.S. Fish and Wildlife Service and the Department of Agriculture-Forest Service or are split mineralestate holdings where the surface has been conveyed to private entities. No Federal uplands sales outside NPRA are scheduled at this time.

TABLE 1A.-Onshore oil and gas lease status, 1982 (see fig. 3)

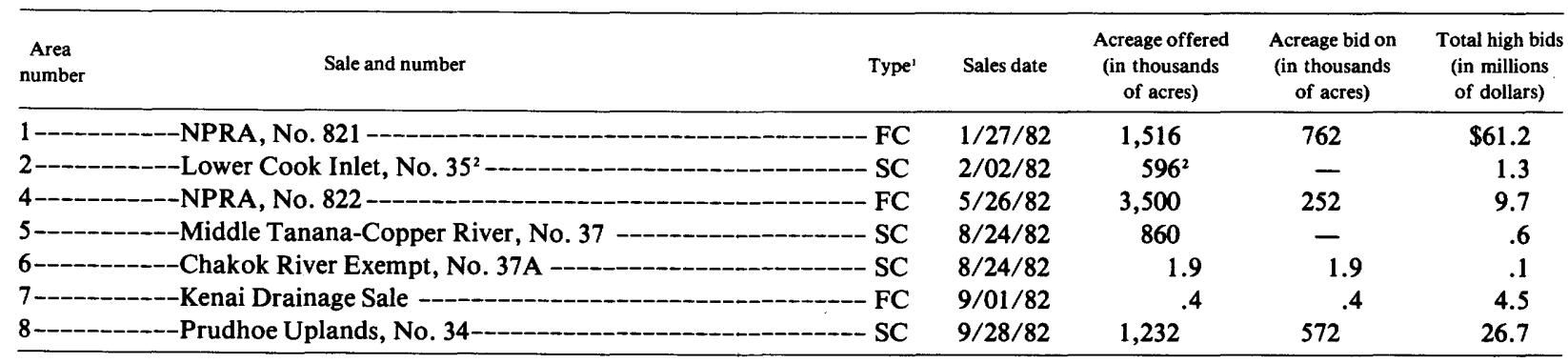

' $\mathrm{FC}=$ Federal competitive sale; $\mathrm{SC}=$ State competitive sale.

${ }^{2} 97$ percent of tracts were offshore. 
TABLE 1B.-Federal noncompetitive offerings, 1982 (see fig. 3)

\begin{tabular}{|c|c|c|c|}
\hline $\begin{array}{c}\text { Area } \\
\text { number }\end{array}$ & $\begin{array}{c}\text { Area } \\
\text { opened }\end{array}$ & $\begin{array}{l}\text { Opening } \\
\text { date }\end{array}$ & $\begin{array}{c}\text { Acres } \\
(\times 1,000)\end{array}$ \\
\hline \multirow{2}{*}{\multicolumn{3}{|c|}{$\begin{array}{l}3-3 / 05 / 82 \\
9--13-27 / 82\end{array}$}} & 276 \\
\hline & & & 3,000 \\
\hline
\end{tabular}

\section{ACTIVITY BY FEDERAL AGENCIES IN 1982}

Bureau of Land Management.-The Bureau of Land Management has the responsibility for all mineral leasing of public domain or acquired lands, regardless of which agency is designated as surface land manager. The Bureau began to establish and refine an automated filing and recordation system for Alaska early in fiscal year 1982. As a consequence, all filings are now entered into the Alaska Automated Land Records System (AALRS) with the mineral leasing and mining claim recordation programs totally automated. A computer-generated abstract is available in the Alaska State office and the Anchorage and Fairbanks district offices. The file includes a history of actions and a complete description of the lands applied for in an oil and gas offer to lease, lands rejected, and lands under lease, for example. Automation of this kind has eliminated manual plotting and offers easy recall of information where conflicts or some other needs for the data arise. The system was used effectively for the Minchumina and Denali-Tiekel offerings and the lease sales in the NPRA. All statistical reporting, including summaries of land available for lease, now comes from the automated system.
A Memorandum of Understanding between the Governor of Alaska, the Bureau of Land Management, the Regional Forester for the Department of Agriculture, and the Undersecretary for the Department of the Interior was signed on May 24, 1982. The memorandum established a mutually approved scheduling of study-area analyses prior to any lease offering and identified key contacts in State and Federal offices to facilitate exchange of information and reviews. It also confirmed a commitment to cooperate on land-use planning.

With the passage of ANILCA and establishment of the National Park System units and designation of the FPGP's, many noncompetitive oil and gas filings that had been received prior to passage of ANCSA have been finally adjudicated. In 1982, about 950 applications for lands in FPGP's and 500 applications for lands in newly established National Parks or Monuments were rejected because FPGP's can only be competitively leased and the new park units are not subject to mineral leasing. Decisions on applications for oil and gas leases on lands in the National Wildlife Refuge units will follow completion of the Fish and Wildlife Service's conservation plans.

In establishing and implementing an oil and gas leasing program as required by Section 1008 of ANILCA, the Bureau of Land Management conducted two noncompetitive lease offerings in areas south of latitude $68^{\circ} \mathrm{N}$. The Minchumina area (fig. 3) was the first public land in Alaska to be opened to the full operation of the mineral leasing laws following the passage of ANCSA. Public Land Order No. 6098

TABLE 2.-Onshore exploratory test wells, 1982 (see fig. 4)

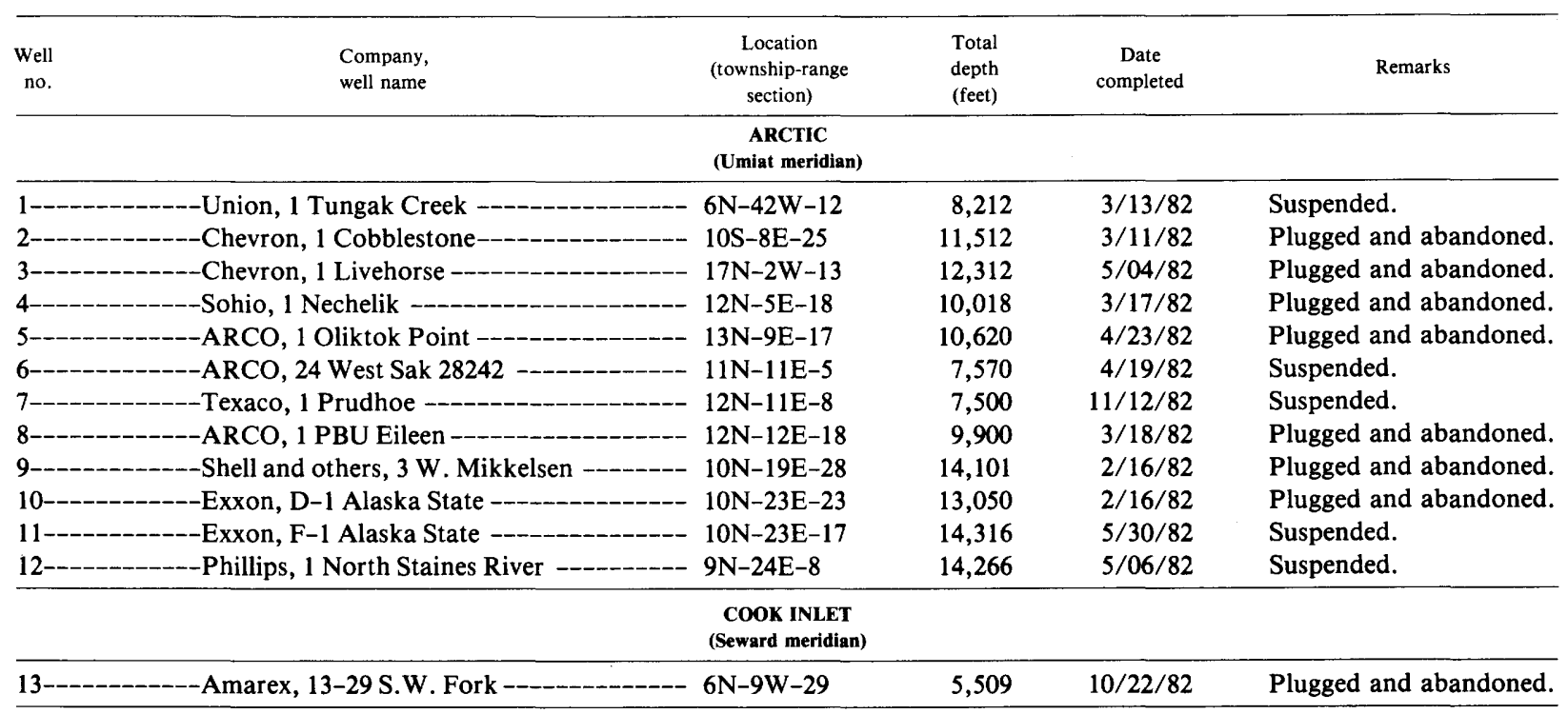




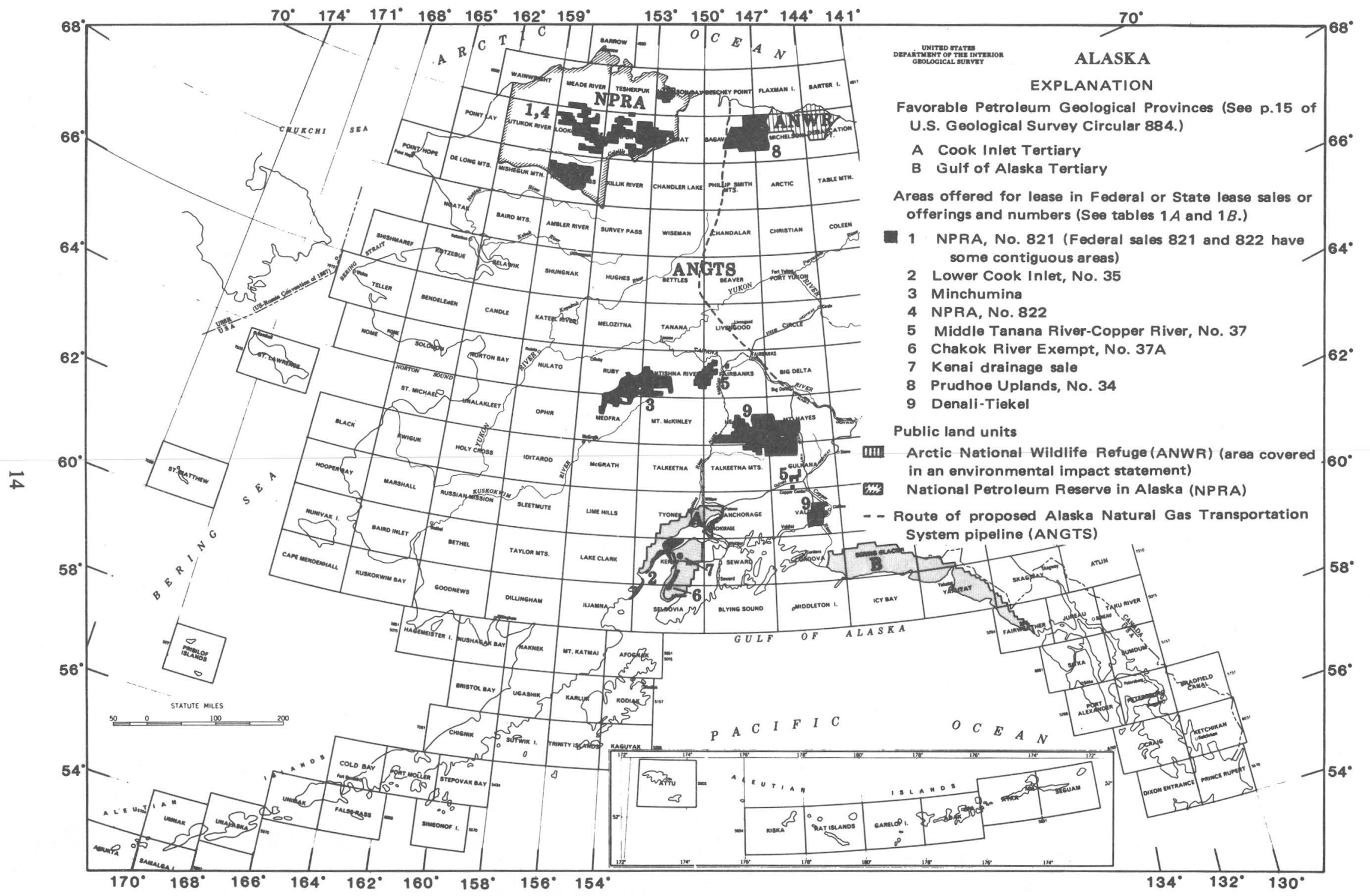

FIGURE 3.-Favorable Petroleum Geological Provinces (FPGP), areas offered for lease, Arctic National Wildlife Refuge study area, proposed gas pipeline route, and public land units. Cape Lisburne FPGP not shown; see text for explanation. 


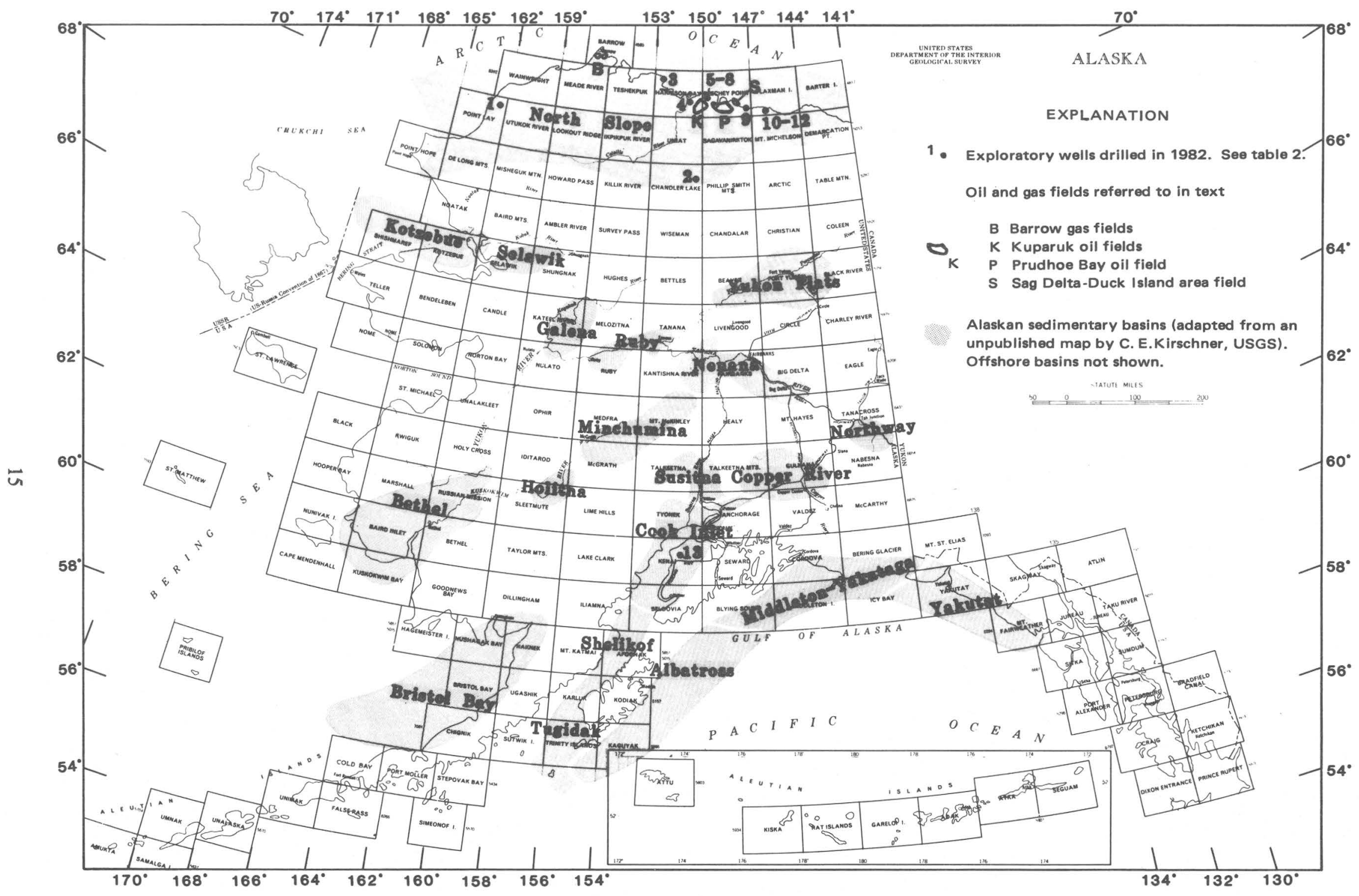

FIGURE 4.- Location of exploratory wells drilled in 1982, oil and gas fields, and Alaskan onshore and nearshore sedimentary basins. 
(December 17, 1981) opened more than 276,000 acres to mineral leasing and 950,000 acres to mining under the general mining laws. Filings received between February 19 and March 5, 1982, were considered simultaneously, and a computerized random selection was made to determine priorities. Later offers were processed as received, with the lands remaining open until leased. As of December 31, 1982, 81 noncompetitive oil and gas leases were issued on a total of 431,455 acres. Such Federal over-the-counter leases are issued with a primary term of 10 years and an annual rental of $\$ 1$ per acre. The second area, DenaliTiekel, was opened by Public Land Order No. 6329 on September 8, 1982, and involved nearly 3 million acres open to mineral leasing and 2,170,108 acres opened to full operation of the mining laws. The initial filing period ended September 27, and, as of December 31, 1982, 79 leases for 429,524 acres had been issued. Any unleased lands remain open to such filings.

Lease sales in the NPRA took place on January 27 and May 26, 1982. Sale 821, the first onshore oil and gas lease sale in 15 years, offered 1,516,257 acres. The amount of acreage receiving bids was 761,766 acres. The total value of the bids was $\$ 61,155,838$. Sale 822 offered $3,434,082$ acres, and bids were received on 252,149 acres. The high bids totaled $\$ 9,741,021$. The Bureau of Land Management's royalty rate on the second sale was set at $162 / 3$ percent with cash bonus. The areas of these sales are shown in figure 3. A draft environmental impact statement concerning oil and gas leasing and development in the NPRA was released in September 1982; the final statement was issued in March 1983, with a decision about future leasing scheduled for April.

The opening of "corridor" lands along the transAlaska oil pipeline route (tentatively scheduled for 1982; see p. 8 of U.S. Geological Survey Circular 884) awaits conclusion of negotiations between the State and Federal Governments and Native corporations.

Because the State has selected extensive parts of the Fortymile and Noatak areas, these lands are now essentially unavailable.

The first oil and gas drainage sale on Federal lands in Alaska was conducted on September 1, 1982, for an area adjacent to the Beaver Creek gas field in the Kenai National Wildlife Refuge. (See table $1 A$ and figure 3.) Sale No. 823 consisted of 400 acres in one parcel. The high bidder, already operating in the area, offered a total bonus bid of $\$ 4,519,000$. Because of the drainage situation, the compatibility determination made by the Fish and Wildlife Service for this area is independent of the compatibility assessment process scheduled for the refuge in 1983 .

The Bureau's Special Projects Office's Annual Report for 1982 (available through the Public Affairs Office, Bureau of Land Management, Federal Building, Anchorage) describes the Bureau's pipeline construction, monitoring, and restoration activities and surveys. While restructuring of the Department of the Interior's responsibilities and a Memorandum of Agreement with the Office of the Federal Inspector were completed in 1982, the Northwest Alaska Pipeline Company withdrew all pending applications for material sales and announced a 2-year delay in the project. The Bureau's involvement with this project is thus sharply reduced.

The Bureau of Land Management held two meetings with industry representatives in March and October 1982. These meetings, termed forums, provided an opportunity for dialogs about drilling stipulations, leasing regulations, conservation measures, Federal studies, and sale schedules, as well as other areas of mutual concern. Records of the forum proceedings are available through the Bureau's Public Affairs Office in Anchorage.

Minerals Management Service.-Studies relating to oil and gas assessment conducted by this agency include investigations of areas bordering Cook Inlet and the Shelikof Straits and the Alaska Peninsula, as well as biostratigraphic and thermal maturation studies for several areas of the State.

The Minerals Management Service also provided area assessments and tract evaluations based on geophysical mapping and analysis of reservoir potential for the two NPRA leases held during 1982, involving a total of 286 tracts and about 5 million acres. A geologic and economic evaluation of a single tract was provided for the competitive offering next to the Beaver Creek field in September 1982. During the latter part of 1982, regional geophysical mapping and stratigraphic analysis were underway in preparation for the third NPRA sale (in 1983), including integration of about 1,200 miles of new seismic data, acquired under permit, with existing Government data. The third sale area consists of about 2.5 million acres in the central, northeast, and north-central parts of the NPRA.

The onshore resource evaluation functions of the Minerals Management Service were merged with those of the Bureau of Land Management in December 1982 .

U.S. Geological Survey.-The North Slope is currently the focus of most Geological Survey studies related to onshore oil and gas resources. These and other studies are highlighted below. 
- The operational phase of the Federal petroleum exploration program in the NPRA was completed in 1981, and more than 30 reports by Survey scientists are currently in the final stages of completion for publication in a U.S. Geological Survey Professional Paper. Topics covered in these reports include stratigraphy, sedimentation, seismic stratigraphy, petrography, paleontology, biostratigraphy, petroleum source-rock geochemistry, structural geology, direct hydrocarbon detection by aeromagnetic and helium methods, subsurface water chemistry, resource assessment methodology, assessment results, economic modeling of assessment results, and exploration history. Most accumulated data from the 1974-81 exploration program, as well as numerous pertinent contractor reports, are available to the public through the National Geophysical and SolarTerrestrial Data Center, Boulder, CO 80303. Their catalog itemizes information about 38 wells, 13,500 line-miles of reflection seismic surveys, 52,000 gravity measurements, and numerous reports on geology, geophysics, the environment, construction, and logistics.

- The two Barrow gas fields of the NPRA (fig. 4) are administered by the Geological Survey. These fields, which supply the village of Barrow with 50 to 75 million cubic feet of gas per month, are operated and maintained by ITTArctic Services, Inc., a subcontractor to the Calista Native Regional Corporation, under terms of a recently awarded contract. In 1982, the Department of the Interior began negotiations to transfer control of the gas fields to Native organizations on the North Slope (Anchorage Times, Oct. 31, 1982, listed at the end of this section).

- Framework geology studies continue for the area east of the NPRA (Central Arctic Management Area and Arctic National Wildlife Refuge). Pertinent 1982 reports for these areas provide rock formations penetrated in exploratory wells (Bird, 1982), computerized well data (Bird, 1982), depositional relations of Tertiary and Cretaceous rocks (Molenaar and others, 1982), and results of a low-level aeromagnetic survey (a report by T. L. Donovan and others to be part of a U.S. Geological Survey Professional Paper about NPRA studies). The reports cited are listed with the Survey's reports at the back of this document.

- The U.S. Geological Survey and the U.S. Fish and
Wildlife Service jointly completed an environmental impact statement for geological and geophysical exploration in the coastal plain part of the Arctic National Wildlife Refuge (fig. 3). An industry seismic program scheduled for winter of 1983 is in doubt because of industry concern about regulations requiring immediate public release of data. At the end of 1982, these regulations were being revised (Petroleum Information, Alaska Report, Sept. 15, 1982).

- A project was initiated in 1982 to evaluate and summarize the petroleum potential of all interior Alaska basins. These basins are located south of the North Slope and generally north of Cook Inlet and are shown in figure 4. The project's studies will synthesize available data, in addition to gathering new data.

U.S. Fish and Wildlife Service. - In keeping with its national mission, the primary efforts of the Service were in protection of fish, wildlife, and habitat on the State's National Wildlife Refuges (NWR). (Figure 1 shows the locations of, but does not name, the NWR's.) However, petroleum-related activities took place on some of the refuges. Oil and gas production continued on the Kenai NWR. Special Use Permits were issued for seismic exploration on the Alaska Peninsula, Kenai, and Yukon Delta NWR's, and a similar permit was issued for erection of temporary navigation towers for aerial geomagnetic surveys to be made on the coastal plain part of the Arctic NWR.

Section 1002 of ANILCA mandates that an assessment be made of the fish and wildlife resources of the Arctic NWR coastal plain and that potential impacts of oil and gas exploration, development, and production be analyzed. Accordingly, the act authorized a baseline study [Section 1002(c)] of biological and other resources and in Section 1002(d) called for development of guidelines to regulate a program of petroleum exploration on the refuge's coastal plain. Only surface geological and geophysical studies are permitted; there is to be no exploratory drilling. The program is to be structured to allow private industry to gather data on the petroleum potential of the area; the data will then be submitted to the Department of the Interior for analysis. Should the private sector choose not to participate in the program, the U.S. Geological Survey may submit a plan to the Fish and Wildlife Service for accomplishing this work.

The Section 1002 assessments are to be contained in a report to the Congress to be submitted not later than September 2, 1986. The draft environmental im- 
pact statement (EIS) and draft regulations were published in September 1982, and the public comment period closed on November 1, 1982. The regulations will prescribe the requirements and procedures for obtaining authorization for and the conduct of exploration activities. The regulations will also set forth procedures for submitting the data to the Department of the Interior. The Fish and Wildlife Service expects that the final EIS and regulations will be published early in 1983 and that exploration may begin in the spring of 1983 . The baseline data gathered under Section 1002(c) were issued in 1982. That and other Service publications are listed under the Service heading at the back of this Circular.

Section 1008 of ANILCA calls for establishing an oil and gas leasing program for lands south of latitude $68^{\circ} \mathrm{N}$., pursuant to the Mineral Leasing Act of 1920 as amended. This program would not apply to NWR's where the Secretary of the Interior determines that exploration or development of petroleum resources would be incompatible with the purposes of the refuges, after having considered the national interest in those resources. In setting up the leasing program, the Service joined the Bureau of Land Management in a Memorandum of Understanding signed May 24, 1982, by the Governor of Alaska that established mutually approved scheduling of leases and identified contacts for expediting the exchange of information and review in the opening of lands for lease. The memorandum noted that the comprehensive conservation planning process [Section $304(\mathrm{~g})$ ] is a means of identifying parts of NWR's where petroleum leasing or other activities would be incompatible with the purpose of the refuges. During 1982, planning focused on the Kenai NWR and, through the Bristol Bay Cooperative Planning Study, the Alaska Peninsula, Becharof, Izembek, and Togiak NWR's. These plans are scheduled for completion in 1983. Plans for all other Alaskan NWR's will be finished by late 1987 .

If an NWR (excepting those parts found to be incompatible) is to be leased by the Bureau of Land Management, such leases are to be competitive if the NWR is in a Favorable Petroleum Geological Province or noncompetitive if located outside these areas. All leasing, exploration, or production would be subject to permits and stipulations designed to protect fish and wildlife; some activities may require environmental assessments or impact statements.

\section{INDUSTRY ACTIVITY IN 1982}

Industry exploration and production activity in
Alaska during 1982 was directed mostly to offshore areas. However, onshore work continued, and highlights of those activities are summarized below.

- The compilation of industry surface geologic investigations is obtained from private scouting services, and 1982 figures will not be available until late 1983. However, an indication of activity is provided by 1981 information. During 1981, surface geologic investigations totaled 17.34 field-crew months, a 60 -percent increase over 1980. Although wide ranging, these investigations concentrated mainly on the North Slope (Jones and Sears, 1982, listed at the end of this section).

- The compilations of data about industry geophysical surveys are also obtained from private scouting sources and will not be available until late 1983. As with the geologic investigations, activity in 1981 suggests the general trend. In 1981 , onshore geophysical surveys consisted of 65.5 field-crew months, a 24-percent increase over 1980. Again, these surveys were in large part conducted on the North Slope (Jones and Sears, 1982).

- Eight companies drilled 13 onshore exploratory wells in 1982, compared to 14 drilled in 1981 . Twelve of these wells were on the North Slope and one in the Cook Inlet basin (table 2). Data from these wells are scarce. Several of the North Slope wells were drilled near known oil fields and have been suspended (Petroleum Information, Alaska Report, various issues in 1982).

- Most major oil companies, many smaller oil companies, and several groups of individuals participated in one or more of the seven competitive lease sales in 1982, and offered about $\$ 104$ million in high bids for about 1.5 million acres of land (table $1 A$ ).

- ARCO Alaska, Inc., initiated a study in 1982 to investigate methods of producing heavy, viscous oil trapped in Upper Cretaceous and Tertiary sandstone reservoirs on the North Slope. These reservoirs lie at relatively shallow depths and overlie the western part of the Prudhoe Bay field and much of the Kuparuk field. They are estimated to contain 18 to 40 billion barrels of oil (Oil and Gas Journal, 1982, v. 80, p. 52).

- The first year's oil production from the Kuparuk field totaled 31.8 million barrels, about 10 percent greater than the operator, ARCO Alaska, Inc., had predicted. Oil production will increase as additional producing wells are completed. Daily production at the end of 1982 was about 
90,000 barrels per day, and a peak production rate of 250,000 barrels per day is projected for 1985. A pilot waterflood program for maintaining pressure in the reservoir is scheduled to start in 1983; the program will augment the current gas-injection program (Anchorage Times, Dec. 14, 1982).

- A pilot project, undertaken by ARCO Alaska, Inc., for enhanced oil recovery, the miscible enriched gas displacement method, was scheduled to be in operation by the end of 1982 for a part of the Prudhoe field. The cost of the program was estimated at $\$ 111$ million. If successful, the amount of oil ultimately recovered from the oil field could be increased 10 to 20 percent over that recoverable by conventional methods. For the Prudhoe Bay field, such an increase is the equivalent of discovering several giant (more than 500 million barrels) oil fields (Oil and Gas Journal, 1982, v. 80, no. 49, p. 118).

- Exxon Company USA, Sohio Alaska Petroleum Company, and partners submitted a preliminary design proposal for development of the Sag Delta-Duck Island discovery (fig. 4) to the U.S. Army Corps of Engineers, as required by law. This discovery, now termed the Endicott Development project, lies offshore just east of Prudhoe Bay. The outline of the field has not been released; the field may extend onshore. The present design could lead to production as early as 1988 , with peak daily production of 75,000 to 150,000 barrels of oil and 250 million cubic feet of gas (Oil and Gas Journal, 1982, v. 80, no. 45 , p. 134 .)

- The proposed Alaska Natural Gas Transportation System (ANGTS) pipeline to tap natural gas in the Prudhoe Bay field remains stalemated by financial problems. (See U.S. Geological Survey Circular 884, p. 20.) In late 1982 , the ANGTS board of directors approved a maintenance-level budget for the first quarter of 1983; completion of the pipeline is now planned for 1989. The Prudhoe Bay field Sadlerochit reservoir is estimated to contain 29 trillion cubic feet of gas (Van Dyke, 1980) and represents about 14 percent of total United States gas reserves (as of December 31, 1981) (U. S. Department of Energy, 1982; see References Cited listed below).

\section{REFERENCES CITED}

Alaska Oil and Gas Conservation Commission Bulletin, published by the State of Alaska Oil and Gas Conservation Commission, 3001 Porcupine Drive, Anchorage, AK 99501.

Alaska Mines and Geology, published quarterly by the State of Alaska Department of Natural Resources, Division of Geological and Geophysical Surveys, P.O. Box 80007, College, AK 99708.

Anchorage Times, 840 W. 4th Ave., Anchorage, AK 99501.

Jones, B. C., and Sears, D. W., 1982, Oil and gas developments in Alaska in 1981: American Association of Petroleum Geologists Bulletin, v. 66 , no. 11, p. 1747-1755.

Oil and Gas Journal, published by Pennwell Publishing Company, 1421 South Sheridan Road, Box 1260, Tulsa, OK 74101.

Petroleum Information, Alaska Report, published by Petroleum Information Corporation, a subsidiary of A. C. Nielsen, P.O. Box 102278, Anchorage, AK 99510.

U.S. Department of Energy, 1982, United States crude oil, natural gas, and natural gas liquid resources, 1981 annual report: U.S. Department of Energy, Energy Information Administration, Office of Oil and Gas, DOE/EIA-0219, $121 \mathrm{p}$.

Van Dyke, W. D., 1980, Proven and probable oil and gas reserves, North Slope, Alaska: State of Alaska Department of Natural Resources, Division of Minerals and Energy Management, $11 \mathrm{p}$.

\section{COAL AND PEAT}

There are 10 medium to large coal fields in Alaska, as well as many isolated occurrences of undefined extent that may be identified as major coal fields after more geologic investigation. The geologic setting and locations of major fields are briefly described in U.S. Geological Survey Circular 884 (1982). Of the major coal fields in the State, three have been of particular interest to industry: (1) Beluga-Capps Glacier, (2) Nenana, and (3) Bering River coal fields (fig. 5).

The State has continued its interest in peat as an energy source. Peat deposits north of Anchorage (fig. 5) have been the focus of recent work by the State and Federal Governments.

\section{ACTIVITY BY FEDERAL AGENCIES IN 1982}

U.S. Geological Survey.-The Geological Survey has been investigating the Cook Inlet coal lands for several years. This study has focused on the nature, location, and extent of geological characteristics important to engineering and design of roads and structures, as well as potential problems that could result from coal mining activities proposed for this area. An important part of this investigation is a drilling operation to determine the physical properties of the coal-bearing rocks and other geologic materials (Chleborad and others, 1982, listed with Federal references at the back of this report). Whenever possi- 


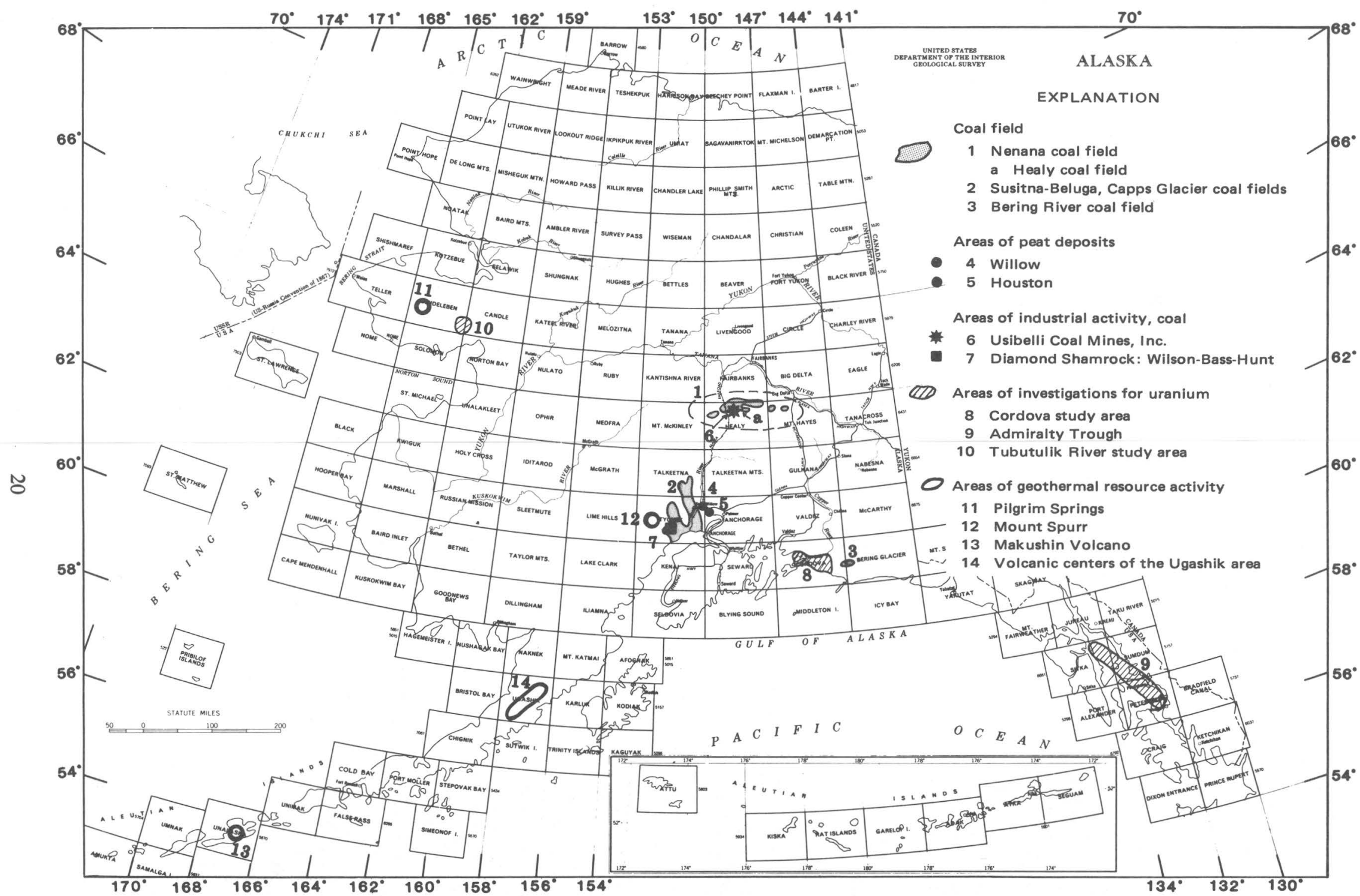

FIGURE 5.-Areas of Federal, State, and industry activity for coal, peat, uranium, and geothermal energy resources. 
ble, coal cores have been collected and submitted for chemical analyses, which show that the coal has low sulfur and moderate ash contents but contains a large amount of water. The Survey also is studying the soils and vegetation to assist in effective reclamation of the area.

\section{STATE STUDIES OF COAL IN 1982}

A study released by the Alaska Division of Geological and Geophysical Surveys indicates that the coal potential of the Susitna Lowland is economically attractive. The reserves in the area typically have low sulfur contents and varying amounts of ash, contain a large number of seams, and are near tidewater. The geochemical and physical characteristics of the overburden rocks are favorable for mining and reclamation. For a full discussion, see Merritt and others (1982), listed with references cited at the end of this section.

Coal reserves in northwest Alaska are being studied by the Alaska Power Authority as a potential energy source for the city of Kotzebue. Coal within a reasonable distance from Kotzebue occurs at Chicago Creek, Corwin Bluffs, and along the Kobuk River. On the other hand, the Alaska Journal of Commerce (February 14, 1983) reports that development of coal north of the Brooks Range is unlikely for the next decade or two.

The Alaska Department of Natural Resources and Governor Sheffield announced that the first competitive coal lease sale in more than 17 years was to be held May 17, 1983, in conjunction with oil lease sale 39. The State offered 1,677 acres of Beluga River field lands. This was to be a pilot sale for a series of offerings, similar to the State's 5-year oil-leasing program.

\section{COOPERATIVE STATE-FEDERAL STUDIES OF PEAT RESOURCES IN 1982}

The Geological Survey reports, in a press release dated October 29, 1982, that the Rogers Creek and Houston aras in the Susitna Valley contain the equivalent of an estimated 5.6 million tons of air-dried peat. The work, by State of Alaska, State of Minnesota, and Geological Survey geologists, resulted in resource maps indicating that the Rogers Creek area contains 3,857,000 tons and the Houston area contains $1,785,000$ tons of air-dried peat. This potentially fuel-grade peat could be collected on approximately $\mathbf{3 0}$ million acres where such work would not be affected by the presence of permafrost.

\section{STATE STUDIES OF PEAT IN 1982}

The State Division of Energy and Power Development has a contract with Wheelabrator-Frye, Inc., to conduct a feasibility analysis for commercial peat processing operations in south-central Alaska for instate and export markets (Petroleum Information, March 24, 1982). The environmental aspects of peat harvesting and processing also will be evaluated.

\section{INDUSTRY ACTIVITY IN 1982}

The following are highlights of the year's industry activities.

- More than 50,000 feet and 200 holes were drilled on the Bass-Hunt-Wilson holdings in the Beluga coal field (fig. 5) by the Diamond Shamrock Corp. The drilling will provide information for future mine planning, environmental protection measures, control of aquatic biota, and engineering considerations. According to Petroleum Information (February 2, 1983), Diamond Shamrock obtained permission late in January to proceed with mining a 250-ton sample for two to five planned boiler burning tests. If market conditions, currently under study, are favorable, Beluga coal could be produced as early as 1987 .

- The \$2.3-billion Beluga coal liquification plant, proposed by Cook Inlet Region, Inc., and Placer-Amex, will not get Federal aid to promote synthetic fuels development. PlacerAmex indicated that the partnership had not obtained sufficient equity or a participant with refining and chemicals experience (Anchorage Times, Sept. 20, 1982); the application has since been withdrawn.

- The Suneel Shipping Company of South Korea has agreed to buy 800,000 metric tons of coal over the next 15 years from Alaska's major operating mine, Usibelli Coal Mines, Inc., at Healy (Nenana coal field, fig. 5). The coal will move by rail from Healy to Seward, an ice-free port on Prince William Sound, for shipment to South Korea. Unexpectedly high costs for coal handling facilities at Seward have delayed the expected start of coal shipments from 1982 to early 1983 (Petroleum Information, March 24, 1982).

- The Usibelli mine currently produces about 800,000 tons of coal annually, according to reports in the February 14, 1983, issue of the Alaska Journal of Commerce and the February 2, 1983, 
edition of the Alaska Economic Report. Most of this coal is used by military facilities and for generating electricity for use in Fairbanks. The agreement with Suneel and the Korea Electric Power Company could double the amount of coal mined annually, and the Korean power company has expressed interest in as much as 1.2 million tons annually. [The Usibelli mine shipped approximately 32,900 tons of coal to Korea for testing in 1980 (S. W. Denton, Usibelli mine, oral commun., 1983).] The Usibelli mine is expected to meet in-state and export demands from coal-burning plants until the mid-1980's.

- The Korean Alaska Development Company, a consortium of four Korean companies, has a joint venture with the Chugach Native Corporation for feasibility studies for exploration and mining of the Bering River coal field (fig. 5). The company was doing exploration studies and reported that the coal is of good steam grade but occurs in badly fractured beds (Petroleum Information, Sept. 8, 1982).

- The Premier Coal Mine in the Matanusk Valley northeast of Anchorage produced about 1,000 tons of coal for local use in 1982 (Eakins and others, 1983, listed in the non-Federal publications section at the back of this report).

\section{REFERENCES CITED}

Alaska Economic Report, published by Alaska Information Service, 3037 S. Circle, Anchorage, AK 99507.

Alaska Journal of Commerce and Pacific Rim Reporter, $715 \mathrm{~L}$ Street, Anchorage, AK 99501.

Anchorage Times, 840 W. 4th Ave., Anchorage, AK 99501.

Merritt, R. D., Eakins, G. R., and Clough, J. G., 1982, Coal investigations of the Susitna Lowlands, Alaska: Division of Geological and Geophysical Surveys Open-File Report 142, $75 \mathrm{p}$.

Petroleum Information, Alaska Report, published by Petroleum Information Corporation, a subsidiary of A. C. Nielson Co., P.O. Box 102278, Anchorage, AK 99510.

\section{URANIUM}

Uranium exploration in the United States remained at a near standstill because of low demand, large supplies, and, consequently, low prices. The resulting slowdown in uranium exploration in Alaska is compounded by high logistical costs of exploration there.

\section{ACTIVITY BY FEDERAL AGENCIES IN 1982}

Department of Energy. - The data-gathering phase of the Department of Energy's uranium studies in
Alaska has been completed, and no new studies have been initiated. The Department does, however, continue to release the results of previous studies and has published numerous reports on hydrogeochemical and stream-sediment studies during 1982. The releases are listed at the back of this report under the Department's heading.

U.S. Geological Survey.-Studies of uranium potential in continental sandstone in the southern end of the Admiralty trough in southeastern Alaska (fig. 5) are complete (Dickinson and Campbell, 1982, listed with selected Survey references at the end of this report). In the Admiralty trough area, the Tertiary Kootznahoo Formation includes nonmarine sandstone with abundant carbonaceous material and is a favorable host rock for sandstone-type uranium deposits. Nearby Tertiary rhyolitic volcanic rocks and alkali granite are favorable uranium source rocks. Weak epigenetic uranium enrichment was noted in outcrop. No commercial or ore-grade uranium deposits have been found, but they could exist subsurface.

Studies of the distribution of uranium and thorium in the lower Teritary Orca Group and related rocks in the Cordova area (fig. 5) were completed in 1982 (Dickinson and Morrone, 1982, listed with selected Survey references). These studies, which were initiated because of radioactive anomalies in the area, show that the Orca Group rocks are not potential uranium producers. The anomalies are apparently the result of contrasting uranium contents within the Orca Group and between the Orca Group and related granite instrusive rocks. Parts of the Orca Group derived from sedimentary rock contain more than twice as much uranium as parts derived from basalt. All values are far below ore grade, and none represent uranium enrichment.

During 1982, fieldwork was carried out along the Tubutulik River about 100 miles east of Nome on the Seward Peninsula (fig. 5) in an epigenetic sandstonetype uranium deposit. Additional work there is planned.

The Geological Survey also has released an openfile map compilation of radioactive anomalies from data collected under contract to the Department of Energy (Dickinson and others, 1983, listed with selected Survey references).

\section{INDUSTRY ACTIVITY IN 1982}

Industry uranium exploration in the State continued to decline in $\mathbf{1 9 8 2}$. There is virtually no current activity. 
The Anaconda Minerals Company completed its contract to Cook Inlet Region, Inc., a Native corporation. This contract had called for reconnaissance work for a variety of minerals including uranium.

Eakins and others (1983, listed with non-Federal reports at the back of this Circular) reports that the Standard Metals Corporation did some exploration work at Bokan Mountain in southeastern Alaska in 1982.

\section{GEOTHERMAL RESOURCES}

Geothermal resources in Alaska currently are being used only locally, for recreational purposes, space heating, and agriculture. The widespread volcanic activity in the Aleutian Islands, the Alaska Peninsula, the Wrangell Mountains, and elsewhere throughout the State, however, points to numerous areas of anomalous subsurface heat flux indicative of a large geothermal energy potential. Quantitative estimates of the potential geothermal energy and the selection of individual sites for further exploration are being conducted now in several localities (fig. 5).

The Aleutian volcanic arc and the western end of the Wrangell Mountains appear to have the highest potential for development of large-scale energy sources. The western end of the Wrangell Mountains lies adjacent to major transportation routes and could provide electrical energy for use in Alaska. The potentially large geothermal areas in the remote Aleutians and the Alaska Peninsula are expected to be of most economic use to the local fishing industry or to industries that have high energy requirements for processing raw material (for example, aluminum) rather than for power transmission outside those areas.

The thermal springs in interior and southeastern Alaska appear to represent deeply circulating water of atmospheric origin, termed meteoric water. Despite lower estimates of subsurface temperatures than from the Aleutian Islands and Alaska Peninsula thermal springs, the demand for cheaper energy in the remote regions of interior Alaska may cause these small thermal springs sites to be the first geothermal area to be developed in the State.

\section{ACTIVITY BY FEDERAL AGENCIES IN 1982}

U.S. Geological Survey.-The Geological Survey is completing studies of volcanic centers that have potential near-surface heat reservoirs on the Alaska Peninsula, concentrating on Peulik, Ugashik, Kialag- vik, Chiginigak, and Yantarni Volcanoes, all in the Ugashik quadrangle (highlighted in fig. 5). These volcanic centers have produced silica-rich ash or lavas in geologically recent times, indicative of possible shallow magma chambers and correspondingly shallow heat reservoirs. The present study has concentrated on understanding the age and characteristics of the volcanic centers so as to estimate the magnitude of their heat conent and resulting geothermal potential.

\section{STATE STUDIES IN 1982}

Republic Geothermal, Inc., under contract to the Alaska Power Authority, conducted a drilling and preliminary geothermal development program on the flanks of Makushin Volcano on Unalaska Island in the eastern Aleutian Islands. Makushin Volcano is a large, historically active stratavolcano with a summit caldera. The 1982 drilling program measured temperatures of $393^{\circ} \mathrm{F}\left(195^{\circ} \mathrm{C}\right)$ at a depth of 1,485 feet; temperatures of this magnitude are indicative of a possible geothermal resource. A 1983 program is being planned to search for suitable reservoirs of hot water or steam.

The Department of Natural Resources in late 1982 called for geothermal exploration permit applications on 16 tracts totaling 10,200 acres in the Mt. Spurr area 70 miles west of Anchorage. Mt. Spurr, a large, historically active volcanic complex, is part of the Aleutian volcanic arc. Each of the 16 tracts received more than 1 application, requiring that the tracts be offered on a competitive bid basis. A lease sale covering 10,240 acres was scheduled for May 17, 1983, in conjunction with a State oil and gas lease and a coal lease.

The Alaska Energy and Power Development Agency continued work at Pilgrim Springs on the Seward Peninsula 90 miles north of Nome. Four more holes were drilled in 1982; this work confirmed the presence of a shallow reservoir at a depth of 75 to 125 feet and a temperature of $200^{\circ} \mathrm{F}\left(95^{\circ} \mathrm{C}\right)$.

\section{NONFUEL MINERALS}

The potential for development of Alaska's nonfuel mineral resources has been in public focus repeatedly in 1982 and early 1983. Professional societies, Federal and State agencies, and trade advocacy groups for varied interests have sponsored meetings, published documents, and lobbied legislatures about the promise of mineral resource development in Alaska. A partial listing of public activities follows: 


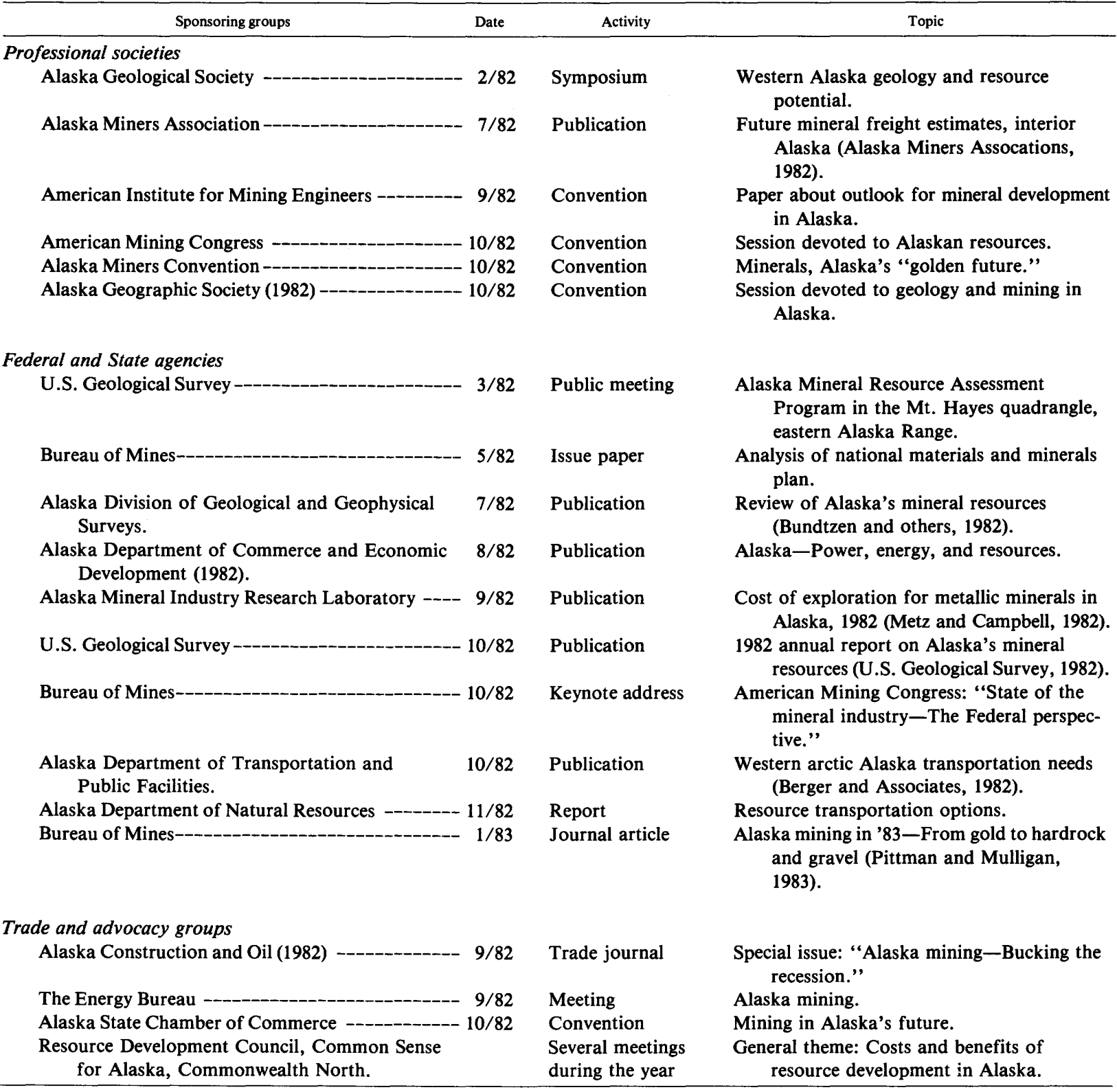

Most references cited above are listed with nonFederal publications, at the back of this Circular.

In addition, three private companies, U.S. Borax and Chemical Company, Noranda Exploration, Inc., and Cominco Alaska, Inc., held public meetings or sent representatives to speak to conventions to explain their plans for feasibility studies and development of their respective properties at the deposit at Quartz Hill near Ketchikan, at Greens Creek in southeastern Alaska, and at Red Dog in northwestern Alaska.

The perennial Alaskan impediments to development of mineral resources-(1) the inadequacy or lack of transportation infrastructure, (2) unresolved land ownership or other land access and use constraints, (3) high costs of exploration and development, and (4) remoteness from markets-also were subjects of meetings too numerous to cite individually. Industry, Native corporations, and the State Government will be negotiating plans for financing of infrastructure construction during the coming year.

In 1982 and early 1983, although the United States' mineral industry agrees with the consensus that hardrock minerals may well be Alaska's greatest undeveloped resource, their caution in proceeding with ex- 
ploration and development clearly mirrored the worldwide economic slump. The result was that, although the dollar value of total mineral production statewide in 1981 increased by 19 percent to $\$ 189.4$ million and increased slightly in 1982 to an estimated $\$ 197.4$ million (table 3), exploration levels in Alaska in 1982 were reduced by an estimated 50 percent and in 1983 may be reduced as much as 40 percent more. According to Alaska Construction and Oil (January 1983 , listed with non-Federal publications at the back of this report), the gross value of exploration activities decreased to an estimated $\$ 50$ million in 1982 from \$76 million in 1981; Eakins and others (1983, listed with non-Federal references at the back of this Circular) give exploration expenditures at $\$ 45$ million for 1982 .

New mining claims filed in 1982 on Federal and State lands $(13,972$, of which 2,879 were on Federal lands) were nearly 50 percent fewer than in 1981 $(27,400)$. Also, the claim blocks staked were smaller. Fewer claims in smaller blocks suggest less activity by the major exploration companies. Claim records give no indication of the very considerable exploration activities on the approximately 44 million acres of land that have been or will be conveyed to the Native regional corporations. Many of these corporations have been increasing the emphasis on mineral resources when developing criteria for selecting their remaining land entitlements. Some already have prospects and partly explored mineral deposits that may be developed into major producers. Several regional corporations have entered into contracts, joint ventures, or other arrangements with mineral exploration consultants and mining companies to ob- tain the resources and expertise necessary to bring major deposits to the production stage.

Gold mining in the State appears to have stabilized at about 1,000 operations, most of small scale. However, production continues to increase, probably due to improved mining techniques and increased efficiency. In 1981, gold production increased by an estimated 80 percent over the previous year to 134,000 troy ounces-or approximately 12 percent of the United States production. In 1982, gold production increased again, to approximately 175,000 troy ounces (Eakins and others, 1983, listed at the back of this report), almost all of which was produced from about 350 mines. The average price received for gold is believed to have dropped from about $\$ 460$ per troy ounce in 1981 to nearly $\$ 400$ in 1982 . Presently, gold production accounts for about 30 percent of the value of Alaska mineral production and about 60 percent of the value when sand and gravel are excluded. Corporate expenditures on mining projects in the early development stages-that is, Quartz Hill, Greens Creek, and Red Dog-grew from \$24.5 million in 1981 to $\$ 39$ million in 1982 and are expected to increase again in 1983. Eakins and others (1983) report that private exploration, development, and production expenditures totaled \$283 million in 1982 .

The trend of company exploration activities related to minerals in Alaska is unclear. One sixperson exploration office opened in February 1982 and then closed in early 1983. Another nine-person exploration office is to be phased out in 1983. However, several large companies made large investments in exploration in 1982. Other companies curtailed exploration, and at least one company only continued

TABLE 3.- Value of minerals produced in Alaska

[From the Anchorage Daily News (Jan. 23, 1983) and Alaska Office of Minerals Development and Division of Geological and Geophysical Surveys]

\begin{tabular}{|c|c|c|c|c|}
\hline Commodity & 1981 value & 1982 value & $\begin{array}{l}\text { Percent } \\
\text { change }\end{array}$ & $\begin{array}{c}1982 \text { national } \\
\text { average unit } \\
\text { price }^{1}\end{array}$ \\
\hline Gold-----------_--_-_------- & $\$ 55.2$ million & $\$ 69.4$ million & +26 & \$397/oz selling. \\
\hline Tin -- & 700,000 & 1.36 million & +94 & $\$ 5.90 / \mathrm{lb}$ \\
\hline Silver -- - & 111,000 & 200,000 & +80 & $\$ 8.00 / \mathrm{oz}$ New York. \\
\hline Sand and gravel ${ }^{2}--$ & 88.3 million & 91 million & +3 & $\$ 3.10 /$ ton f.o.b. plant. \\
\hline Building stone $^{2}--$ & 26.3 million & 15.4 million & -41 & $\$ 3.70 /$ ton. \\
\hline Total - & $\$ 189.4$ million & $\$ 197.4$ million $^{3}$ & & \\
\hline
\end{tabular}

'From Bureau of Mines Mineral Commodity Summaries 1983.

${ }^{2}$ Not considered in this Circular.

${ }^{3}$ Eakins and others (1983) gives $\$ 196.4$ million for this total. 
feasibility studies on its claims in a major mineral district. Many company activities in 1982 were related to the provisions of ANILCA that claimants to Federal lands in the Steese and White Mountains Conservation Areas must prove discoveries and secure ownership of more than 7,500 claims in the area by September 1982.

The strong interest in Alaska's mineral resources is indicated convincingly by the rapid growth in membership in the Alaska Miners Association to more than 1,500 persons including representatives of more than 20 major mineral corporations. State agencies such as the Department of Commerce and Economic Development (through its Office of Mineral Development and Office of Special Industrial Projects) and the Department of Transportation and Public Facilities (through its evaluation of expansion of the railroad to major mining districts in the western Brooks Range) have adopted advocacy roles in the promotion of mineral resource development in Alaska. John Sims, Director of the Office of Mineral Development, announced at an Alaska State Chamber of Commerce meeting in Fairbanks in October 1982 that he expects that the Alaska mining industry will grow from $\$ 200$ million per year to $\$ 2$ billion within 10 years. The Department of Natural Resources (through its Division of Geological and Geophysical Surveys (DGGS) and the University of Alaska's Mineral Industry Research Laboratory) has published several mining district studies. (See Bundtzen, 1982a; Dillon, 1982; Forbes, 1982; Forbes and Weber, 1982; Hitzman and others, 1982; Metz and Campbell, 1982; Hawkins, 1982; Wescott, 1982; and Robinson, 1982 , listed with non-Federal publications at the back of this Circular.) DGGS also announced in August 1982 that it is acquiring from Los Alamos Scientific Laboratories 2.5 million geochemical analyses from 60,000 samples that were collected by the Department of Energy in Alaska. These data will be made available by the State in both hard copy and computer tape forms.

Three additional factors may lead to increased mineral resource activity in Alaska soon:

(1) The pending transfer of the Alaska Railroad to the State of Alaska. Studies by the Alaska Miners Association (AMA) and the Alaska Department of Transportation and Public Facilities indicate the feasibility of extending the railroad northwestward and the likelihood of economic development in the western interior and the southwestern Brooks Range as a result. The AMA estimates that, with such expansion, Alaska might have 2.2 million tons of hardrock production and 23 million tons of coal production annually by the 1990's.

(2) The pending selection of 10 million additional acres of State lands, some of which have been chosen for their mineral resource potential or for access to resources on present State lands.

(3) Announcement by the Bureau of Land Management of a stepped-up mineral leasing schedule on Federal lands, with the first 4 million acres to be in the Denali and Tiekel blocks.

\section{ACTIVITY BY FEDERAL AGENCIES IN 1982}

U.S. Geological Survey.-The statewide Alaska Mineral Resource Assessment Program (AMRAP) and the Roadless Area Resources Evaluation (RARE II) and Wilderness Study program in Prince William Sound-Kenai Peninsula area continued at approximately the same levels of activity as in 1980 and 1981 . Work funded by the Office of National Petroleum Reserve in Alaska (ONPRA) in northwestern Alaska is nearing completion. In addition, a final joint report by the Geological Survey and the Bureau of Mines was issued for the West Chichagof-Yakobi Wilderness study area in the Tongass National Forest of southeastern Alaska. Locations of areas studied in 1982 are depicted on figure 6 , and table 4 lists the projects that are included.

AMRAP functions at four levels of progressively greater detail to produce comprehensive assessments of Alaska's mineral and energy endowment. In level I, which is statewide at a scale of $1: 2,500,000$, summaries of occurrences of specific commodities such as copper continued (Cobb, 1982e, listed at back of this report), and new summaries for molybdenum, tungsten, and lode and placer gold (Cobb, 1982b, c, $\mathrm{d}, \mathrm{f})$ were prepared. In level II, which is regional at a scale of $1: 1,000,000$, a single project is continuing in southeastern Alaska; a preliminary report was issued in 1982 (Berg and others, 1981, listed at the back of this section). In level III of AMRAP, mineral and energy resource assessments are underway for 15 1:250,000-scale quadrangles that are judged to have significant potential in the north-central Brooks Range, the Seward Peninsula, the Yukon-Tanana Upland, the eastern Alaska Range, the Alaska Peninsula, and southeastern Alaska. Figure 7 shows the current status of AMRAP level III studies. In level IV, which consists of detailed studies at a scale of $1: 63,360$ or larger of mineral districts, specific deposits, or topics related to the formation of deposits, 23 continuing projects are scattered throughout the State. Many level III and IV studies 


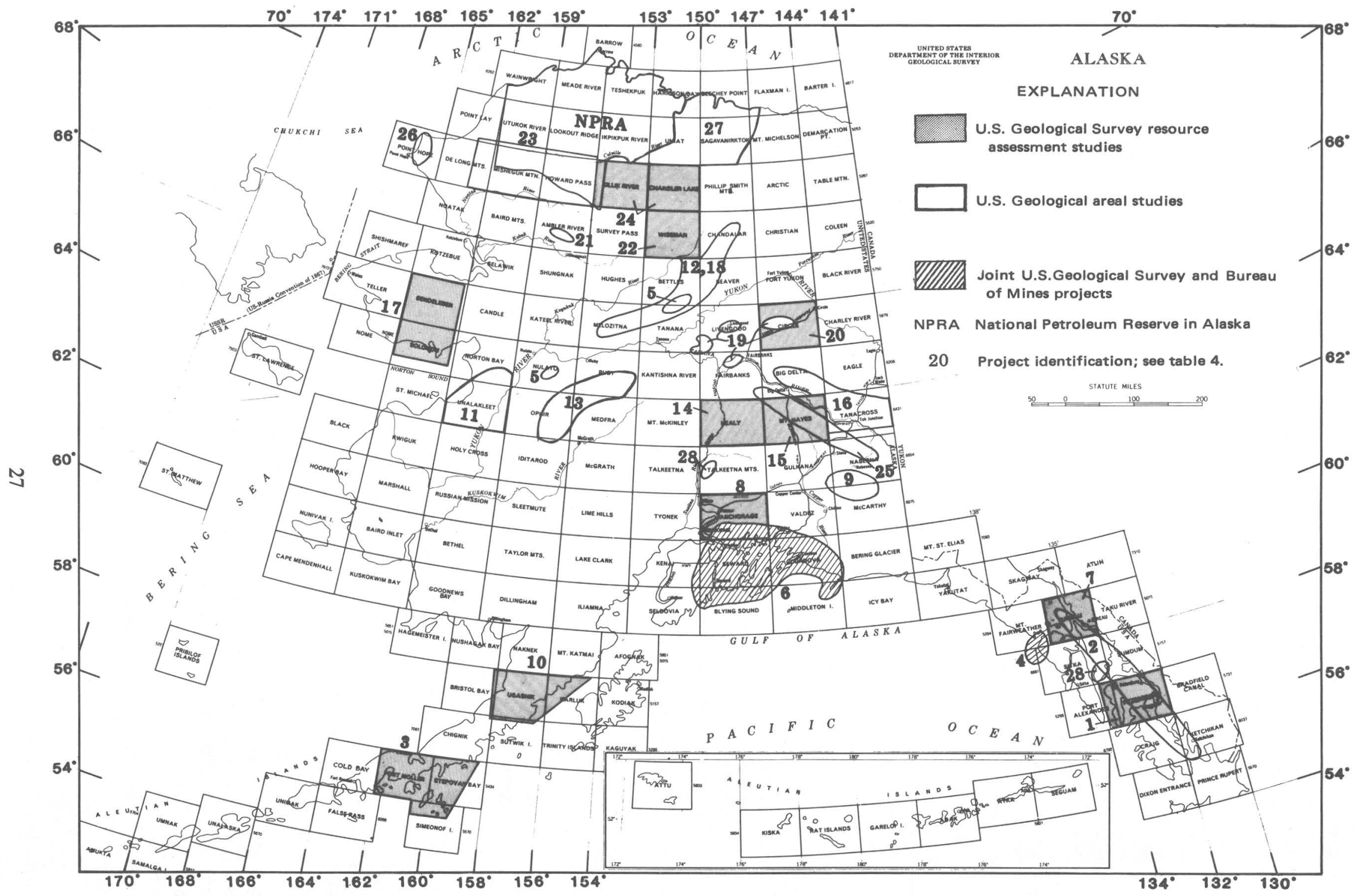

FIGURE 6. - Locations of areas studied by the U.S. Geological Survey and the Bureau of Mines for nonfuel, critical, and strategic minerals. See table 4 for titles or brief descriptions of projects. 
TABLE 4.-Abbreviated titles or brief descriptions of projects whose study areas are shown in figure 6

[The patterns of the figure distinguish resource assessment studies (such as AMRAP), areal studies, and projects undertaken jointly by the U.S. Geological Survey and Bureau of Mines]

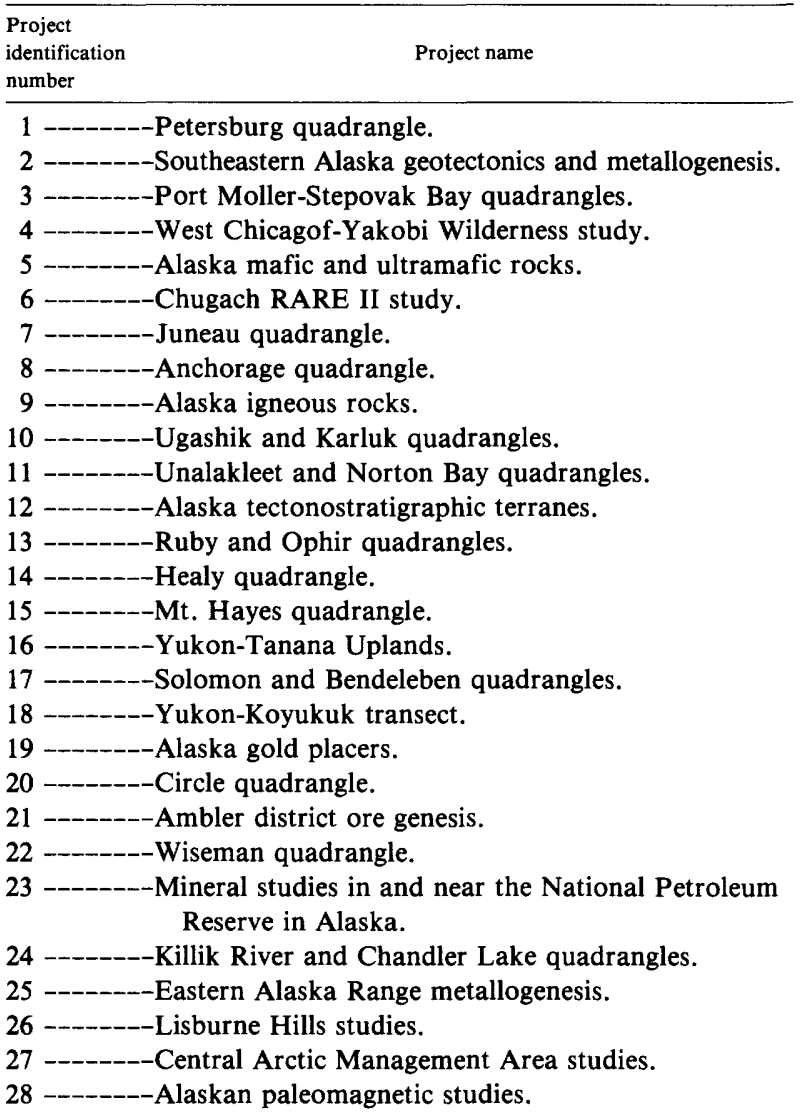

are made in cooperation with scientists from other Federal, State, or Canadian agencies and from educational institutions. More than 60 publications resulting from these level III and IV studies are listed in the section listing selected references at the back of this Circular.

Fieldwork was completed in 1982 on a joint RARE II and wilderness study project by the Geological Survey and the Bureau of Mines that encompasses more than 5.6 million acres in the Chugach National Forest of southern Alaska. A mineral and energy resources assessment at a scale of $1: 250,000$ is in preparation for this Prince William Sound-Kenai Peninsula region; it will be completed in 1983. Preliminary reports summarizing detailed Bureau of Mines' investigations of gold, molybdenum, copper, and manganese occurrences in the Prince William Sound area were published in 1982 (Fechner and Meyer, 1982; Kurtak, 1982; listed with Bureau reports at the back of this Circular).
Recent field studies by the ONPRA in the western Brooks Range, with Geological Survey and Bureau of Mines participation, have been concluded. Numerous interim reports have been issued from 1978 to 1982 about the NPRA, and additional work under the auspices of AMRAP will begin in 1983 in the western Brooks Range.

Bureau of Mines. - Two programs of the Bureau of Mines provide information about the nonfuel minerals potential of Alaska. The mineral land assessment program provides evaluations of specific occurrences on Federal lands throughout the State. Mineral land assessments for occurrences in western Prince William Sound, the western Brooks Range, and Yakobi Island were completed in 1982.

The minerals availability program collects, summarizes, stores, and updates information on occurrences statewide. Mineral properties are identified, located, and selected for evaluation through the Minerals Industry Location System (MILS). Property identification is initiated by the evaluator's determination on either a commodity or an areal basis. Basic information about a property is coded by the evaluator for inclusion in the MILS computer data bank. During 1982, more than 6,000 MILS entries were compared with the Geological Survey's Computerized Resource Information Bank, and 2,919 cross indexes were established. Coordination also was initiated with the various agencies involved in issuing licenses and permits for mining, with the goal of increasing up-to-date information in the MILS data base.

If sufficient information for a reserve determination exists for a property, the deposit record is forwarded for a Minerals Availability System (MAS) evaluation that addresses the quantity and quality of the commodity present, the determination of mining and beneficiation technologies for its extraction and recovery, the calculation of capital and operating costs, and the institutional restraints on the minerals availability. The resulting information is stored in the Bureau of Mines' mainframe computer. Twelve MAS deposit evaluations were completed during 1982 for lode and placer deposits in Alaska. Review of 23 previously completed mineral deposit evaluations indicated that 7 evaluations contained outdated information and would require MAS reevaluation.

Information about obtaining MILS or MAS products such as data printouts or computer-plotted overlays can be obtained from the Chief, Alaska Field Operations Center, Juneau, Alaska.

The Bureau of Mines, the University of Alaska's Arctic Environmental Information and Data Center, 


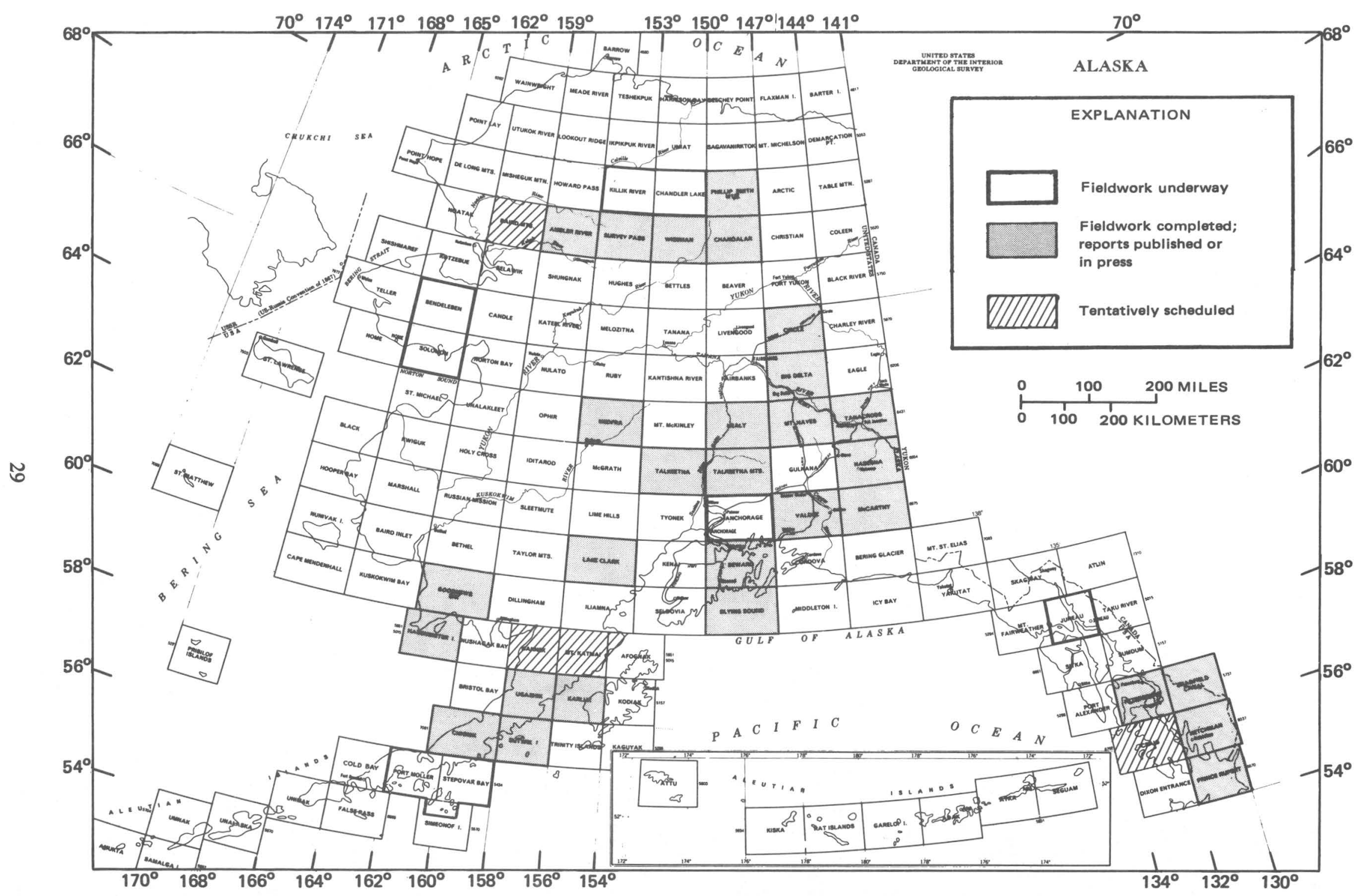

FiguRE 7.-Status of Level III Alaska Mineral Resource Assessment Program studies, January 1, 1983. 
the Alaska Division of Geological and Geophysical Surveys, and members of the mineral industry have cooperated to update the map series "Mineral Terranes of Alaska"' (University of Alaska, 1982, listed with non-Federal publications in the selected references at the back of this Circular), a series of $1: 1,000,000$-scale maps with explanatory text that summarizes current knowledge of Alaska's mineral potential. The series is designed for reference by policymakers and land managers, but companies, Native groups, and other private organizations also have been highly interested in the map series.

Bureau of Land Management.-The Bureau of Land Management approved for patent two sets of claims for gold placers in 1982. One set is in the Cache Creek district (south-central Alaska) and contains 27 claims; the other is about 40 miles east of Talkeetna and consists of 13 claims.

The Bureau also held a noncompetitive offering in Minchumina area. Public Land Order No. 6098 (1981) opened more than 276,000 acres to mineral leasing, 950,000 acres to mining under general mining laws, and additional acreage for settlement. The area is thought to have potential for gold, silver, copper, bismuth, tungsten, thorium, and rhenium but littie potential for oil and gas or commercially important coal.

U.S. Fish and Wildlife Service.-In keeping with the Service's primary mission, major efforts relating to mineral activities in Alaska have emphasized fish, wildlife, and habitat protection. However, a total of 1,495 valid mining claims on Alaska's National Wildlife Refuges (NWR) were current during 1982. These consisted of 1,117 lode claims ( 3 patented) and 378 placer claims, tabulated below:

\begin{tabular}{|c|c|c|}
\hline Refuge & Lode claims & Placer claims \\
\hline Alaska Peninsula NWR - & 132 & 2 \\
\hline Arctic NWR - & 83 & 2 \\
\hline Becharof NWR - & 0 & 1 \\
\hline Innoko NWR - & 2 & 0 \\
\hline Kenai NWR - & 0 & 19 \\
\hline Nowitna NWR & 0 & 4 \\
\hline Koyukuk NWR -- & 247 & 29 \\
\hline Tetlin NWR-- & 0 & 4 \\
\hline Togiak NWR-- & 272 & 163 \\
\hline Yukon Delta NWR - & 5 & 102 \\
\hline Yukon Flats NWR - & 345 & 52 \\
\hline Selawik NWR - & 33 & 0 \\
\hline
\end{tabular}

In addition, there are two mill sites on the Arctic NWR and nine mineral survey applications on file for the Togiak NWR. No current mining claims are on the Alaska Maritime, Izembek, Kanuti, or Kodiak NWR's.

\section{INDUSTRY ACTIVITY IN 1982}

The following paragraphs highlight recent industrial activity. Areas of interest or activity are shown on figure 8 and table 5 .

- U.S. Borax and Chemical Corporation activities at its molybdenum prospect at Quartz Hill in southeastern Alaska near Ketchikan continued to receive media coverage. In March 1982, the Forest Service approved 9.5 miles of access road along the Blossom River for moving bulk samples, but legal challenges prevented the start of road construction until September 1982. (The Ninth Circuit Court of Appeals ruled that an environmental impact statement is required for the bulk sampling operation.) Road completion is expected by mid-1983. Collection of predevelopment environmental data continued in the interim. Core drilling also continued, but at a reduced level from that of 1981; 4 holes were cored in 1982 as compared to 10 in 1981 . Total drilling to date is more than 250,000 feet, which has outlined a deposit of more than 1.5 billion tons grading 0.136 percent molybdenite $\left(\mathrm{MoS}_{2}\right)$. Site selection and land acquisition near Gray's Harbor, Wash., were completed in late 1982 for the corporation's leaching and roasting plants to concentrate and refine the ores from Quartz Hill. Initial mine operation plans calling for removal of 60,000 tons of material per day were submitted to the Forest Service in November 1982; this request triggered the environmental impact statement process. If the plans are approved (possibly by late 1983), construction may begin in late 1984, leading to initial production in 1987. However, if molybdenum prices remain at depressed levels ( $\$ 6.85$ in 1982 v. $\$ 9.70$ in 1980), U.S. Borax may reduce initial production by one-third, to 40,000 tons per day. At full production, the mine is expected to employ 850 people, initially 60 to 70 percent of these from Alaska, for the mine life of 70 years.

- In May 1982, Noranda Exploration, Inc., a major partner in the joint venture, submitted its environmental assessment report for its Greens Creek silver-lead-zinc-gold-copper properties on Admiralty Island in southeastern Alaska near Juneau to the Forest Service. It also announced updated and greatly expanded development plans for this deposit. To date, more than $\$ 11$ million has been expended for exploratory work, including excavation of a 


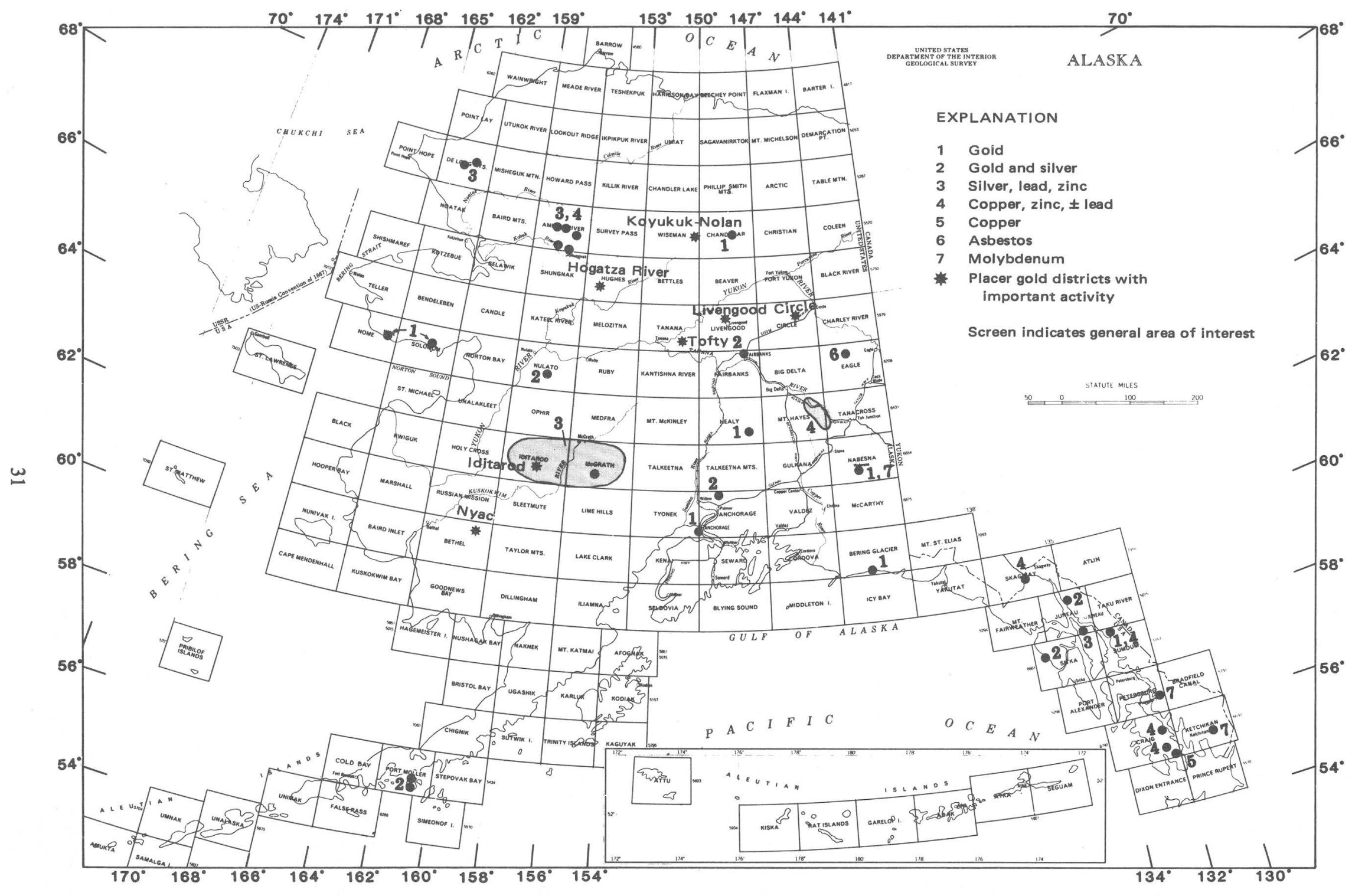

FIGURE 8. -Areas of important industrial activity for nonfuel minerals. 
TABLE 5.-Areas of industry activity for nonfuel minerals [Locality numbers are taken from figure 8]

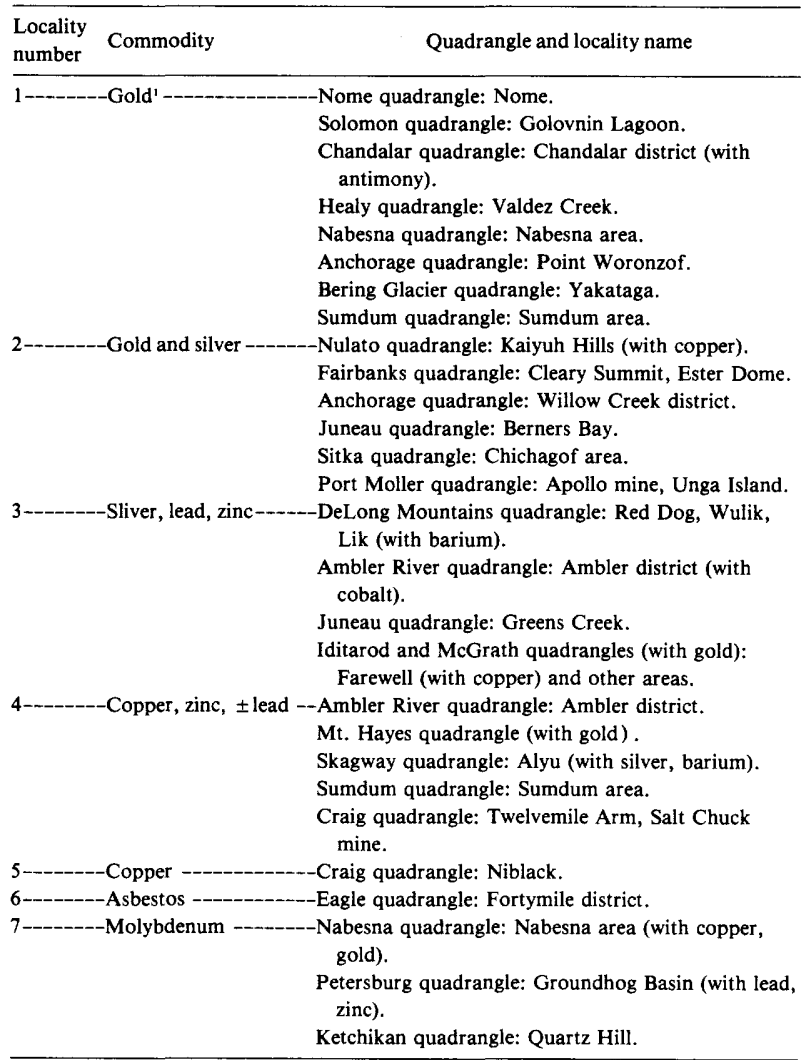

'Actively worked placers statewide; too numerous to show at figure 8 scale. Some important regions indicated by pattern on figure 8 .

4,200-foot adit and more than 48,000 feet of core drilling. More than 3 million tons of reserves have been delineated. Expenditures should increase more than ninefold in the next 4 years as existing facilities are expanded and roads, milling, and tailings disposal facilities are constructed to bring the mine into operation by 1986 . From 225 to 315 workers, to be based in Juneau, will be employed at the mine through its 15-year life expectancy. Other companies involved in the project are Bristol Resources, Inc., a subsidiary of the Bristol Bay Native Corporation, Texas Gas Exploration, and Exalas Resources. (In May 1983, Anaconda Minerals Company acquired one-third interest in this property.)

- In January 1982, Cominco Alaska and NANA, a regional Native corporation, reached final agreement on a 2-year feasibility study and potential development of the Red Dog zinclead-silver deposit in the Noatak district of northwestern Alaska. Exploration to date has delineated more than 85 million tons of ore, which occurs in nearly horizontal beds and is thus suitable for open-pit mining. An additional 15,000 feet of core drilling was completed during 1982. Transportation corridors 55 and 70 miles long to tidewater are being studied. Cominco Alaska and NANA prefer the shorter southern corridor that must cross the northern edge of Cape Krusenstern National Monument. The final decision on whether to develop the mine is expected to be made in 1983. If the decision is to proceed, production should begin in approximately 5 years, after construction of a 5,000-foot airstrip, an onsite mill to handle 2,500 tons of material per day, tailings containment, a concentrate storage and shipping facility at tidewater, and a railroad or road to tidewater. A work force of approximately 220 people will be required during the projected 50-year life span of the mine; the initial goal is 50 percent local hire, and ultimately 100 percent local hire.

- The potential for development of the Ambler district in the southwestern Brooks Range was also frequently in the news during 1982. Although the lack of transportation infrastructure means that development is probably more than a decade away, numerous prospects such as Arctic, Sun, Picnic, Smucker, and Ruby Creek have published reserves of rich copper, silver, lead, zinc, and cobalt ores in excess of 100 million tons with a value of $\$ 6$ billion to $\$ 12$ billion, depending on fluctuating mineral prices. In its predevelopment studies of the Arctic prospect, Bear Creek Mining Company suggests the feasibility of a 9,000-tons-per-day open-pit operation over a 50 -year life, to include milling on the property. However, transportation of the concentrated product has yet to be resolved. A study by the Alaska Department of Transportation and Public Facilities has estimated that extending the Alaska Railroad from Nenana to the southwestern Brooks Range would cost about $\$ 1.3$ billion but eventually could aid exploration and development, not only in the Ambler district, but also in other areas of northwestern Alaska. The potential of the southwestern Brooks Range is regarded so favorably by the State that it has (1) jointly published with the Anaconda Company a full-color geologic map of the Ambler district (Hitzman and others, 1982, listed with non-Federal publications at the back of this 
report) and (2) tentatively selected additional State lands in the Bettles-Evansville-Alatna Hills area and in the Koyukuk-Melozitna area largely to guarantee potential access westward from present transportation corridors. The apparent need for an access route across the southern extension of the Gates of the Arctic National Park is under discussion by Federal and State agencies.

- Further analysis of asbestos properties in the Eagle district by WGM, Inc., and GCO, Inc., as joint venture partners with Doyon, Ltd., a Native regional corporation for interior Alaska, indicates resources considerably in excess of the published 55 million tons. Feasibility studies were beginning in late 1982, with the first step being large-scale bulk testing to determine the marketability of the asbestos. Permission to construct a 40-mile-long winter road westward from the Taylor Highway for access to the properties has been requested from the Bureau of Land Management. If a favorable development decision is made, production of 2.2 million tons of ore per year could begin by 1990 , and operations could employ as many as 500 people.

- In southern Alaska, the Enserch Corporation on August 12, 1982, formally reopened the Independence lode gold mine in the Willow Creek district of the Talkeetna Mountains. A mill rated at 140 to 150 tons per day was installed; the mining rate planned was 200 tons per day, 5 days a week. Problems developed in milling the extremely fine gold in the ore, and the mine was closed again in late November.

- In the interior, near Fairbanks, the Grant gold mine blocked out additional reserves. The Ryan gold lode on Ester Dome and gold properties on Cleary Hill and Pedro Dome are nearing production. The DGGS has published a report that examines the efficiency of goldrecovery methods used at the Grant mine (Conwell, 1982, listed with non-Federal references at the back of this Circular).

- In the Chandalar district of the east-central Brooks Range, operations continue seasonally at the Little Squaw gold mine at a peak production of 100 tons per day. Expansion of the production rate is planned for 1983. During the summer of 1982, a discovery of gold-antimony-quartz veins was made in the district. The DGGS has published a report that discusses the source of gold in the district (Dillon, 1982, listed with
non-Federal publications at the back of this Circular).

- On Unga Island near the southwest end of the Alaska Peninsula, Alaska Apollo Gold Mines, Ltd., has announced three additional goldbearing veins parallel to, and within 3,500 feet of, the mineralized zone along which the present adit is located. The property produced gold from 1888 to 1908 . The veins carry significant silver, lead, and copper values, in addition to gold. The company has initiated rehabilitation of the properties, including dewatering the shafts, clearing collapsed drifts, and extensive channel sampling underground, and is preparing to reopening the mine. An article in the May 1982 issue of World Mining estimates reserves at 2 million tons grading from 0.15 ounces of gold per ton, 5 ounces of silver per ton, 1.2 percent lead, 1.0 percent zinc, and 0.4 percent copper.

- The Denali Mining Company's placer gold operation at Valdez Creek on the south side of the central Alaska Range has closed, and the property is for sale. This was the largest placer mine in southern Alaska.

- In southeastern Alaska, several of the old gold mines are being reevaluated. Near Berners Bay, Hyak Mining Company investigated the Vunlin mine, and Placid Oil Company examined the Kensington and adjacent claims. On West Chichagof Island, Exploration Ventures Company, Inc., explored in the Chichagof mine area, and Enserch Exploration, Inc., investigated the Hirst-Chichagof area.

- Other areas of continuing active company exploration for precious and base metals in Alaska during 1982 were the Seward Peninsula, the southwestern and central Brooks Range, western Alaska (especially the Kaiyuh Hills and Farewell area but also large parts of the YukonKuskokwim region), the Alaska Range, and southeastern Alaska. No major new discoveries or significant expansion of known mineral deposits have been made public.

- Exploration, and drilling at some deposits, is underway at the following areas in southeastern Alaska: Salt Chuck mine for copper and gold (in addition to platinum-group elements); Sweetheart Ridge, Jingle Jangle, and Sumdum, for copper, zinc, and gold; and Niblack and Twelvemile Arm for copper.

- Placer mining activities were widespread in the State in 1982 and accounted for 60 percent of 
the total mining revenues, excluding leaseholding fees. Dredges operated at Nome, Nyac, and the Hogatza River; large-scale placer operations were carried out in the Circle, Fairbanks, Iditarod, Livengood, Solomon, Tofty, and Wiseman districts. Figure 9 shows locations of these areas.

\section{REFERENCE CITED}

Berg, H. C., Decker, J. E., and Abramson, B. S., 1981, Metallic mineral deposits of southeastern Alaska: U.S. Geological Survey Open-File Report 81-122, 145 p., 1 sheet, scale $1: 1,000,000$.

\section{CRITICAL AND STRATEGIC MINERALS}

During 1982 and early 1983 there was continuing emphasis in industry and Government on advertising Alaska's significant potential for chromium, cobalt, nickel, platinum-group metals, tin, tungsten, and manganese, but, because of the national economic slump, there was less emphasis on active exploration for these critical and strategic commodities. Tin, especially, received relatively less attention than in previous years. Alaska's tin potential is large, and the locations of numerous deposits are well known, but production beyond the reported estimated 99 tons of concentrate annually (Eakins and others, 1983, listed with non-Federal publications at the back of this Circular; G. R. Eakins, oral commun., 1983) is unlikely in the current market situation. In addition, important reserves of mercury, fluorite, tungsten, and antimony are present in the State.

In the second quarter of 1982, the State of Alaska sponsored a market feasibility study for chromium, cobalt, nickel, and platinum-group metals, all of which occur in Alaska in promising quantities. The market study, by Charles River Associates (1982) and Van der Poel and Hawley (1982), followed up an inventory of Alaska's resources of strategic minerals presented in January 1982 at an international mineral symposium sponsored by the American Association for the Advancement of Science (Bundtzen, 1982b, listed with non-Federal publications). The first part of the market study (Charles River Associates, 1982) forecasted how future market conditions (supply and demand, prices, potential for disruption of supply, transportation, and international trade factors) might affect five Alaskan deposits or undiscovered analogs elsewhere in the State. The five deposits selected for this analysis were Goodnews Bay (platinum-group elements), Lost River (tin and fluorine), Ruby Creek (copper and byproduct cobalt), Red Mountain (chromium), and Brady Glacier (nickel, copper, cobalt, and platinum-group elements). The second part of the marketing study (Van der Poel and Hawley, 1982) considered the geologic setting, character, land status, and potential production (taking into account capitalization needs and operating costs) of these five deposits and where additional analogous deposits might be located in the State. Although the commercial viability of Alaskan deposits of critical and strategic minerals is promising in the long run, the market study suggests that only Goodnews Bay and Lost River have near-term potential.

Development of deposits of nickel, cobalt, and platinum in southeast Alaska is constrained by land status mandated by ANILCA. Ninety-two percent of Alaska's proven nickel reserves, more than 90 percent of known cobalt resources, and almost 50 percent of known platinum resources are on lands in southeastern Alaska that are withdrawn from development-Brady Glacier, Yakobi Island, and Mirror Harbor on western Chichagof Island. However, there is also significant, but not well defined, potential for cobalt at the Ruby Creek prospect in the Ambler district in the southwestern Brooks Range. It is also likely that significant resources of strategic minerals are present elsewhere in Alaska and will be located with modern exploration techniques.

\section{ACTIVITY BY FEDERAL AGENCIES IN 1982}

U.S. Geological Survey.-Two current projects in AMRAP pertain to critical and strategic minerals. A level IV study of chromium, nickel, and platinumgroup elements associated with layered mafic and ultramafic rocks in interior Alaska is continuing. Fieldwork in 1982 concentrated on rocks in the Mt. Hurst, Yuki River, and Kanuti River areas. A level IV geological, geophysical, and geochemical study of the Yukon-Koyukuk region is continuing, and fieldwork in 1982 included sampling tin-bearing rocks in the Hodzana Highlands of eastern interior Alaska. In addition, an update of occurrences statewide of selected critical and strategic minerals was completed (Cobb and St. Aubin, 1982, listed with Survey publications at the back of this report), and a Level III mineral resource assessment is being prepared for the Goodnews Bay region, which contains the largest reserves of platinum in the United States. Locations of these projects are included on figures 6 (items 5, 11, and 12) and 7, and project titles are included on table 4.) 
Bureau of Mines. - Statewide reconnaissance investigations of reported occurrences of cobalt, chromium, and the platinum-group metals continued in 1982. Investigations of tin and related metals were started. Figure 9 shows the areas that were being investigated; table 6 lists the localities and prospect names in each of the areas. In addition, the cobalt content of samples from the Omar prospect in the western Brooks Range was evaluated (Jansons, 1982, listed in the references at the back of this report), and, in cooperation with the U.S. Geological Survey, the mineral resource assessment of the West Chichagof-Yakobi Island Wilderness area, which includes significant resources of nickel and cobalt, was completed (Kimball, 1982, listed at the end of this report). Bureau of Mines' reconnaissance investigations do not include drilling or detailed quantitative sampling. Industry data and facilities are used wherever possible. (In areas that are closed to entry, Bureau of Mines' investigation schedules are reviewed by the local area managers and modified if necessary before investigations proceed.)

The first phase of a reconnaissance investigation is to determine the mineralogy and geologic setting of each occurrence or group of occurrences and to roughly estimate their extent and grade. Normally this requires at least two visits to an area, each followed by mineralogical and quantitative sample analysis and mapping of results. If the initial investigation indicates that a deposit, or a group of deposits, has potential national value, bulk samples are obtained and analyzed to determine metallurgical characteristics and to estimate recoverability. The metallurgical work is performed at the Bureau of Mines Albany Research Center in Albany, Oreg. Special determinations are made at the Juneau laboratory or in appropriate commercial laboratories.

One such study of chromite occurrences in central Alaska was published in two parts in early 1983 (Foley and McDermott, 1983; Bureau of Mines, 1983; listed at the back of this report). A similar study of chromite potential is underway in the Chugach Mountains of southern Alaska.

\section{INDUSTRY ACTIVITY IN 1982}

Following are highlights of industrial activity in critical and strategic minerals in 1982 and early 1983. Locations are shown in figure 10 and further defined in table 7.

- Anaconda Copper Company continued its drilling program at Red Mountain near Seldovia on lands belonging to the Cook Inlet Region, Inc.,
TABLE 6.-Locality and prospect names, to accompany figure 9 [Further information about these localities is available from the Bureau of Mines Juneau office]

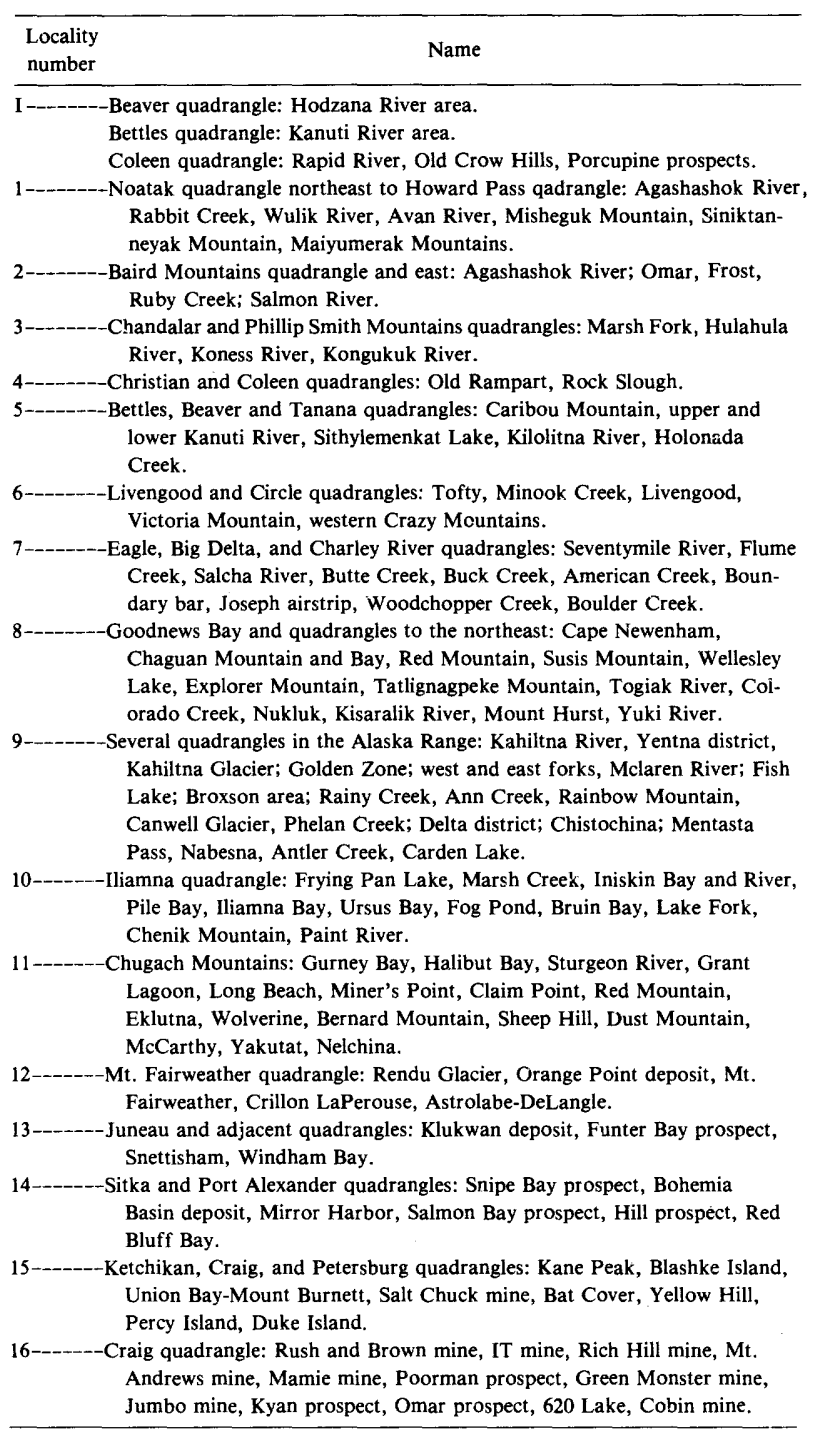

a Native corporation, and to Chugach Natives, Inc., with the intent of better defining the potential of deposits that supplied emergency production of chromite during World War II and the Korean War. Present published estimates are 300,000 tons of 28-percent chromite. These deposits may be the largest low-grade chrome reserves in the United States.

- Phillips Minerals announced in June 1982 the closure (to be completed in January 1983) of the Anchorage office of their Strategic Minerals Division, which had a staff of about 20 people. Phillips had active exploration programs in western and southeastern Alaska during 1982 and now will be attempting to transfer 


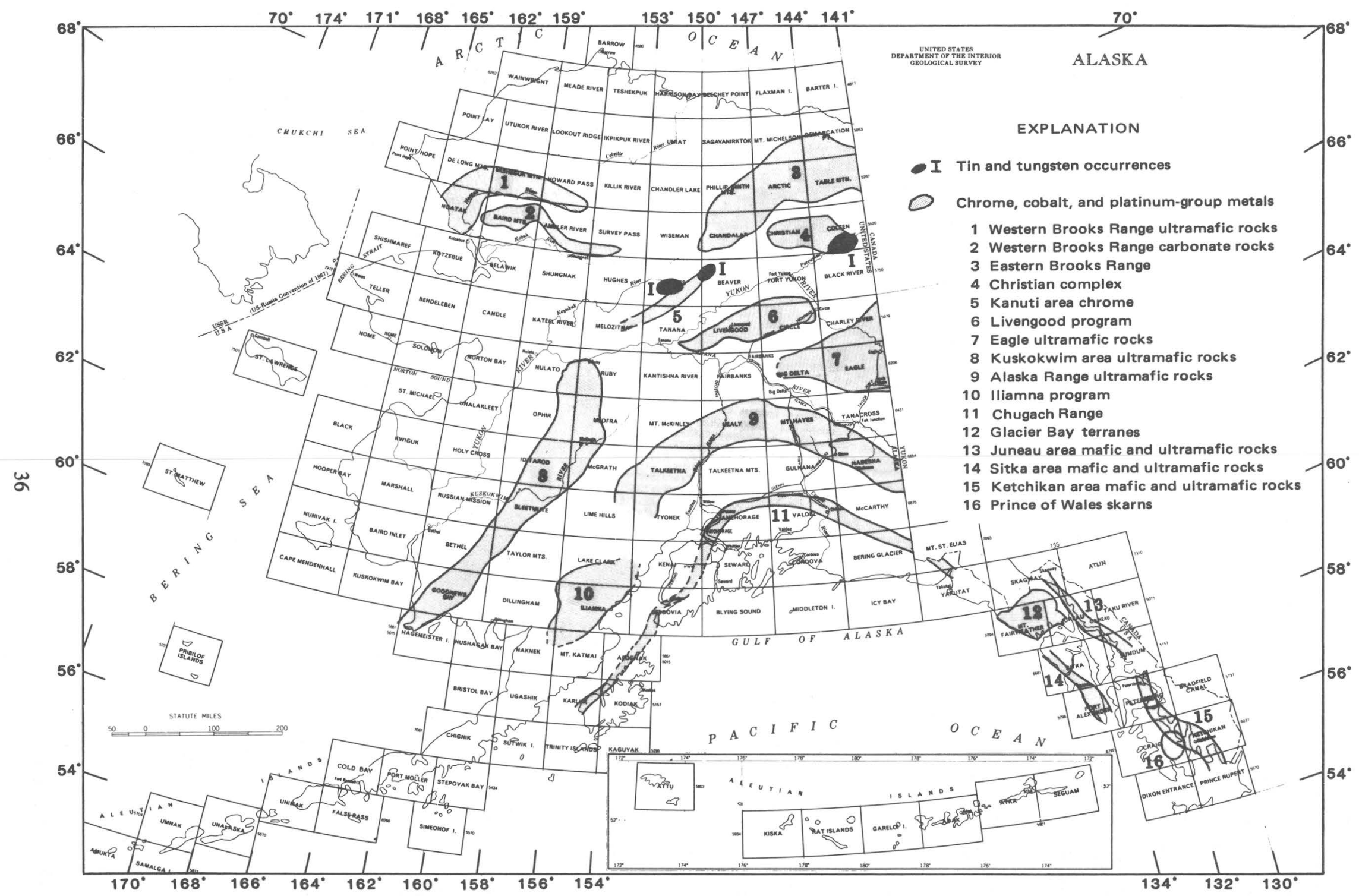

FiguRE 9.-Areas of Bureau of Mines' investigations for critical and strategic minerals in 1982. See table 6 for locality or area names. Dashed lines indicate inferred extensions of areas containing these minerals. 


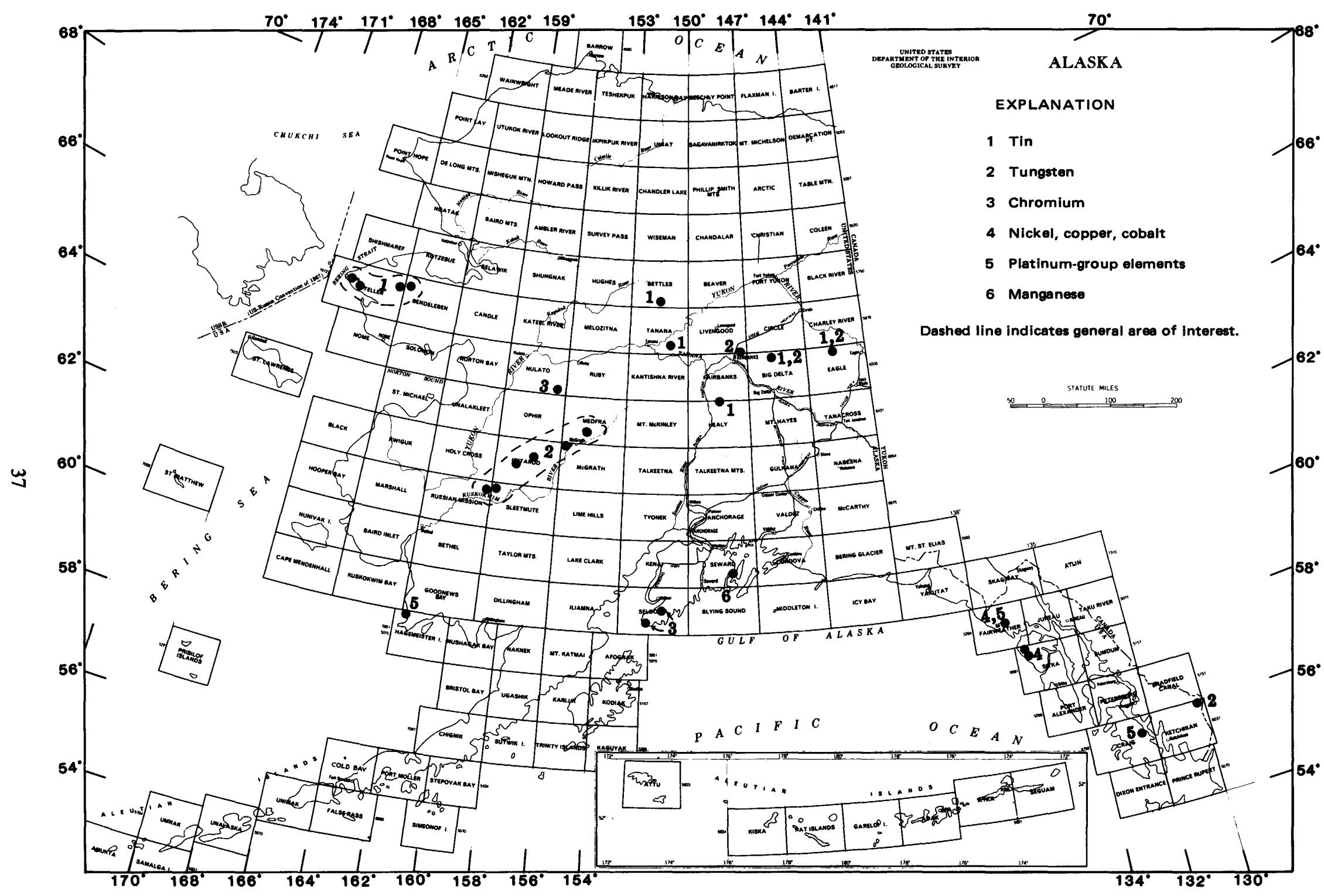

FIGURE 10.-Areas of industrial activity for critical and strategic minerals in 1982 and early 1983 . See table 7 for locality and prospect names by quadrangle. 
TABLE 7.-Localities of interest for critical and strategic minerals, to accompany figure 10

[For further information, contact the Bureau of Mines Juneau of fice]

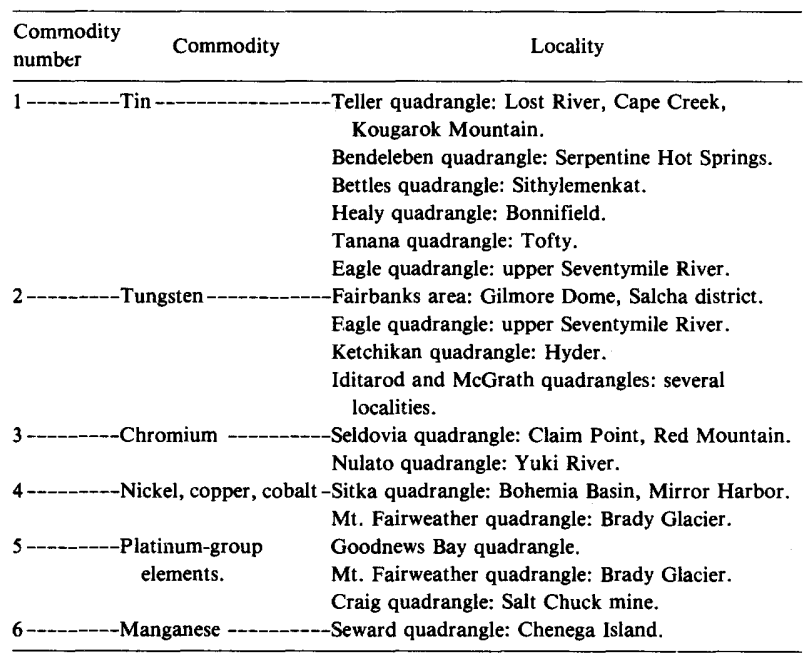

ownership of their claims. Other exploration companies also cut back drastically on budgets and personnel.

- Chugach Natives, Inc., announced in December that manganese deposits discovered by the U.S. Bureau of Mines in 1981 on Chenega Island in western Prince William Sound will be offered to mining companies on a joint venture basis for exploration. The extent of the deposits is uncertain, but they apparently occur entirely on Native lands. The regional corporation hopes to sponsor thorough investigations by industry.

- Exploration and drilling continues at the Bohemia Basin and Mirror Harbor nickel-copper-cobalt deposits. A joint study by the owners and the Bureau of Mines to determine the distribution and potential recovery of platinum-group elements from the deposits is being conducted. A joint summary report of a Bureau of MinesGeological Survey study of the area is in press.

- Exploration and drilling at the Salt Chuck copperpalladium-platinum mine, owned by Orbex Minerals Limited, continued into 1982 with geophysical exploration.

Other areas of continuing active company exploration for critical and strategic minerals during 1982 included for chromium, C. C. Hawley and Associates in the Yuki River area; for cobalt, Bear Creek Mining Company at Ruby Creek; for tungsten, Houston International Minerals Company in the Salcha area; and for tin, Resource Associates of Alaska and Bear Creek Mining Company at Bonnifield, Houston
International Minerals Company, Union Carbide, and Resource Associates of Alaska in the Salcha area, and Anaconda Minerals Company and Placid Oil Company in the western Seward Peninsula, especially in the Kougarok Mountain area west of the Serpentine Hot Springs area. The potential for niobium and tantalum also was investigated near Serpentine Hot Springs.

\section{REFERENCES CITED}

Charles River Associates, 1982, Strategic mineral markets for platinum group metals, chromium, cobalt, nickel and tin, Vol. I of Strategic Mineral Markets and Alaska Development Potentials: State of Alaska, Division of Policy Development and Planning, Policy Analysis Paper 82-12, 7 chapters and 2 appendixes individually paginated.

Van der Poel, W. I., and Hawley, C. C., 1982, Potentials for mining chrome, cobalt, nickel, platinum group metals, and tin in Alaska, Vol. II of Strategic Mineral Markets and Alaska Development Potentials: State of Alaska, Division of Policy Development and Planning, Policy Analysis Paper 82-12, 76 p. and 2 appendixes.

\section{SELECTED REFERENCES}

The following lists of references released in 1982 or early 1983 have to do with various aspects of mineralrelated activity by Federal and other agencies in Alaska. It is not a complete list of publications of any agency. For example, reports about the determination of earthquake epicenters, basic hydrologic data or research, or bathymetry and geology of offshore areas are not included, though that information may be important to some facets of mineral investigations.

The U.S. Geological Survey regularly publishes its findings in several types of reports. A monthly listing titled "New Publications of the Geological Survey" is available free from the Geological Survey, $329 \mathrm{Na}$ tional Center, Reston, VA 22092; the contents of the list are compiled annually into a free book titled "Publications of the Geological Survey [year]." Prices and addresses of the offices from which reports can be obtained are given in the monthly listing or are available from the Geological Survey's Public Inquiries Offices.

The Bureau of Mines also publishes a variety of reports describing the results of its investigations. The Bureau of Mines' central distribution office is the Branch of Production and Distribution, 4800 Forbes Avenue, Pittsburgh, PA 15213. Many Bureau of Mines reports are available through the U.S. Government Printing Office in Washington, D.C.; some 
are available through the National Technical Information Service in Springfield, Va. The reports listed herein and an index of the publications about mineral investigations in Alaska from 1911 to 1981 are in the Bureau of Mines's Juneau library. For information about the availability of these reports, contact the Chief, Alaska Field Operations Center, Box 550, Juneau, AK 99802.

Reports prepared by other Federal or State agencies about their mineral-related studies are generally available through the agencies' offices or at the Department of the Interior's Alaska Resource Library, 701 C Street, Anchorage, AK 99513.

[Occasionally an imprint date is not the same as the year of release. A very small number of these reports listed here as having been released in 1982 were actually published in 1983 . It will be possible to obtain such a report by requesting it by the author, title, and report number.]

\section{U.S. GEOLOGICAL SURVEY}

\section{Professional Papers}

Armstrong, A. K., and MacKevett, E. M., Jr., 1982, Stratigraphy and diagenetic history of the lower part of the Triassic Chitistone Limestone: U.S. Geological Survey Professional Paper 1212-A, p. A1-A26.

Armstrong, F. C., ed., 1981 [1982], Genesis of uranium- and goldbearing Precambrian quartz-pebble conglomerates (Proceedings of a workshop, October 13-15, 1975, Golden, Colorado; see especially section $\mathrm{Y}$-Thorianite from the Hogatza placer, north-central Alaska, by H. M. Staatz): U.S. Geclogical Survey Professional Paper 1161-A-BB. (Published as a single volume.)

Nokleberg, W. J., and Winkler, G. R., 1982, Stratiform zinc-lead deposits in the Drenchwater Creek area, Howard Pass quadrangle, Brooks Range, Alaska: U.S. Geological Survey Professional Paper 1209, 22 p.

Smith, R. A., Slack, J. R., Wyant, Timothy, and Lanfear, K. J., 1982, The oilspill risk analysis model of the U.S. Geological Survey: U.S. Geological Survey Professional Paper 1227, $40 \mathrm{p}$.

U.S. Geological Survey, 1982, Geological Survey research 1981: U.S. Geological Survey Professional Paper 1275, 402 p.

\section{Open-file reports}

Albert, N. R. D., 1982, Preliminary map showing reconnaissance photogeologic interpretation of SLAR imagery of the Bristol Bay, Ugashik, and Karluk quadrangles, Alaska: U.S. Geological Survey Open-File Report 82-141, 5 sheets, scale $1: 250,000$.

Barton, H. N., Odland, S. K. O'Leary, R. M., and Day, G. W., 1982, Geochemical data for the Killik River and Chandler Lake quadrangles: U.S. Geological Survey Open-File Report $82-1026,53 \mathrm{p}$.

Berg, H. C., and Cruz, E. L., 1982, Map and table describing fossil collections and related samples in the Ketchikan and Prince
Rupert quadrangles, southeastern Alaska: U.S. Geological Survey Open-File Report 82-1088, 27 p., 1 sheet.

Bird, K. J., 1981, Rock unit reports of 228 wells drilled on the North Slope: U.S. Geological Survey Open-File Report 82-278, 106 p.

1982, Machine-generated displays of well logs and lithology from 12 wells on the North Slope of Alaska: U.S. Geological Survey Open-File Report 82-290, 5 p., 12 pls.

1982, Catalog of digital $\log$ data for government-drilled wells in and adjacent to the National Petroleum Reserve in Alaska: U.S. Geological Survey Open-File Report 82-800, $31 \mathrm{p}$.

Blanchard, D. C., and Tailleur, I. L., 1982, Temperatures and interval geothermal-gradient determinations from wells in $\mathrm{Na}$ tional Petroleum Reserve in Alaska: U.S. Geological Survey Open-File Report 82-391, 82 p.

Bowsher, A. L., 1981 [1982], Proceedings of a workshop on cathrates (gas hydrates) in the National Petroleum Reserve in Alaska, July 16-17, 1979, Menlo Park, Calif.: U.S. Geological Survey Open-File Report 81-1298, 165 p.

Brosgé, W. P., and Patton, W. W., Jr., 1982, Regional bedrock geologic maps along the Dalton Highway, Yukon Crossing to Toolik, Alaska: U.S. Geological Survey Open-File Report 82-1071, 11 p., 1 sheet.

Burns, L. E., 1982, Gravity and aeromagnetic modeling of a large gabbro body near the Border Ranges fault, southern Alaska: U.S. Geological Survey Open-File Report 82-460, 72 p., 3 sheets.

Burrell, P. D., Cobb, E. H., and Brew, D. A., 1982, Geologic bibliography of the Petersburg project area, Alaska: U.S. Geological Survey Open-File Report 82-483, 30 p.

Chapman, R. M., Yeend, Warren, Brosgé, W. P., and Reiser, H. N., 1982, Reconnaissance geologic maps of the Tanana quadrangle, Alaska: U.S. Geological Survey Open-File Report 82-734, 20 p., 2 sheets:

Chleborad, A. F., Yehle, L. A., Schmoll, H. R., Gardner, C. A., and Dearborn, L. L., 1982, Preliminary geotechnical and geophysical logs from drill hole $2 \mathrm{C}-80$ in the Capps coal field, Cook Inlet area, Alaska: U.S. Geological Survey Open-File Report 82-884, 9 p., 2 sheets.

Cobb, E. H., 1982a, Selected Geological Survey, U.S. Bureau of Mines, and Alaska Division of Geological and Geophysical Surveys reports and maps on Alaska released during 1981, indexed by quadrangle: U.S. Geological Survey Open-File Report 82-384, 132 p.

1982b, Lode gold and silver occurrences in Alaska: U.S. Geological Survey Open-File Report 82-406, 32 p., 1 oversize sheet.

1982c, Occurrences of molybdenum minerals in Alaska: U.S. Geological Survey Open-File Report 82-798, 9 p., 1 sheet.

1982d, Occurrences of tungsten minerals in Alaska: U.S. Geological Survey Open-File Report 82-875, 12 p., 1 sheet. 1982e, Occurrences of copper minerals in Alaska: U.S. Geological Survey Open-File Report 82-1029, 32 p., 1 sheet. 1982f, Pacer gold occurrences in Alaska: U.S. Geological Survey Open-File Report 81-1326, 34 p., 1 sheet.

Cobb, E. H., and St. Aubin, D. R., 1982, Occurrences of selected critical and strategic mineral commodities in Alaska: U.S. Geological Survey Open-File Report 82-719, 25 p., 1 sheet.

Craig, J. D., and Thrasher, G. P., 1982, Environmental geology of Harrison Bay, northern Alaska: U.S. Geological Survey 
Open-File Report 82-35, 28 p., 6 oversize sheets, scale 1:250,000.

Curtis, S. M., Ellersieck, Inyo, Mayfield, C. M., and Tailleur, I. L., 1982, Reconaissance geologic map of southwestern Misheguk Mountain quadrangle, Alaska: U.S. Geological Survey Open-File Report $82-611,43$ p., 2 oversize sheets, scale 1:63,360.

Detterman, R. L., Allaway, W. H., Jr., Day, G. W., Hopkins, D. M., O'Leary, R. M., and Svec, Edward, 1982, Locality map for scintillometer and analytical data collected in 1981, Ugashik and Karluk quadrangles, Alaska: U.S. Geological Survey Open-File Report 82-53, 1 sheet, scale 1:250,000.

Dickinson, K. A., and Campbell, J. A., 1982, The potential for uranium deposits in the Tertiary Kootznahoo Formation in the southern part of the Admiralty trough, southeastern Alaska: U.S. Geological Survey Open-File Report 82-983 $20 \mathrm{p}$.

Dickinson, K. A., and Morrone, J. F., 1982, Distribution of uranium and thorium in the lower Tertiary Orca Group and related rocks in parts of the Cordova quadrangle, southern Alaska: U.S. Geological Survey Open-File Report 82-1032, $12 \mathrm{p}$.

Dickinson, K. A., Morrone, J. F., and Roberts, M. E., 1983, Summary of radiometric anomalies in Alaska collected under contract with the U.S. Department of Energy: U.S. Geological Survey Open-File Report 83-169 (in press).

Ellersieck, Inyo, Curtis, S. M., Mayfield, C. M., and Tailleur, I. L., 1982, Reconnaissance geologic map of south-central Misheguk Mountain quadrangle, Alaska: U.S. Geological Survey Open-File Report 82-612, 38 p., 2 oversize sheets, scale 1:63,360.

Elliott, R. L., and Koch, R. D., 1982, Mines, prospects, and selected metalliferous mineral occurrences in the Bradfield Canal quadrangle, Alaska: U.S. Geological Survey Open-File Report 82-728-B, 24 p., 1 sheet, scale 1:250,000.

Friesen, W. B., 1982 Petrography of igneous rocks from Amlia Island, Aleutian Arc, Alaska: U.S. Geological Survey OpenFile Report 82-302, 32 p.

Godson, R. H. [compiled under the supervision of], 1982, Composite magnetic anomaly map of the United States-Part BAlaska and Hawaii: U.S. Geological Survey Open-File Report 82-970, 20 p., 2 sheets, scale 1:2,500,000.

Gough, L. P., Severson, R. C., and Briggs, P. H., 1982, Field observations and chemical analyses of vegetation, soils, and spoil materials, Jarvis Creek preference coal lease, Alaska: U.S. Geological Survey Open-File Report 82-55, 34 p.

Hamilton, T. D., 1982, Quaternary stratigraphic sections with radiocarbon dates, Killik River quadrangle, Alaska: U.S. Geological Survey Open-File Report 82-606, 33 p., 1 sheet.

Hessin, T. D., and Crenshaw, G. L., 1982, Geochemical map showing the abundance of sulfate and fluoride in unfiltered water samples in the West Chichagof-Yakobi Wilderness study area, Sitka quadrangle, southeastern Alaska: U.S. Geological Survey Open-File Report 82-27-P, 1 oversize sheet.

Hessin, T. D., and Day, G. W., 1981, Geochemical map showing the distribution and abundance of cobalt, chromium, and nickel in the nonmagnetic heavy-mineral concentrate samples in the West Chichagof-Yakobi Wilderness study area, Sitka quadrangle, southeastern Alaska: U.S. Geological Survey Open-File Report 81-27-T, 1 oversize sheet.

Hessin, T. D., Everman, W. K., and Crenshaw, G. L., 1982, Map showing stream-sediment samples in the West Chichagof-
Yakobi Wilderness study area, Sitka quadrangle, southeastern Alaska: U.S. Geological Survey Open-File Report 81-27-M, 1 oversize sheet. [All in this series, scale 1:125,000.]

1982, Geochemical map showing the distribution and abundance of copper, zinc, molybdenum, arsenic, and uranium in filtered water samples in the West Chichagof-Yakobi Wilderness study area, Sitka quadrangle, southeastern Alaska: U.S. Geological Survey Open-File Report 81-27-N, 1 oversize sheet.

1982, Geochemical maps showing anomalous patterns for element copper in stream sediments, filtered waters, and nonmagnetic heavy-mineral concentrates in the West ChichagofYakobi Wilderness study area, Sitka quadrangle, southeastern Alaska: U.S. Geological Survey Open-File Report 81-27-O, 1 oversize sheet.

Hessin, T. D., and Hoffman, J. D., 1982, Geochemical map showing the distribution and abundance of cobalt, chromium, and nickel in stream-sediment samples in the West ChichagofYakobi Wilderness study area, Sitka quadrangle, southeastern Alaska: U.S. Geological Survey Open-File Report 81-27-R, 1 oversize sheet.

Hessin, T. D., Maslowski, M. G., and Cooley, E. F., 1982, Geochemical map showing the distribution and abundance of copper, lead, zinc, and barium in the nonmagnetic, heavymineral concentrate samples in the West Chichagof-Yakobi Wilderness study area, Sitka quadrangle, southeastern Alaska: U.S. Geological Survey Open-File Report 81-27-S, 1 oversize sheet.

Hessin, T. D., Maslowski, M. G., and Day, G. W., 1982, Geochemical map showing the distribution and abundance of copper, lead, and barium in stream-sediment samples in the West Chichagof-Yakobi Wilderness study area, Sitka quadrangle, southeastern Alaska: U.S. Geological Survey Open-File Report 81-27-Q, 1 oversize sheet.

1982, Geochemical map showing the distribution and abundance of silver, arsenic, gold, tin, and tungsten in the nonmagnetic heavy-mineral concentrate samples in the West Chichagof-Yakobi Wilderness study area, Sitka quadrangle, southeastern Alaska: U.S. Geological Survey Open-File Report 81-27-U, 1 oversize sheet.

Hinkley, T. K., Smith, K. S., Peard, J. L., and Tomplins, M. L., 1982, Whole-rock chemical composition of some samples from two drill holes in the Capps coal field, Beluga coal area, south-central Alaska: U.S. Geological Survey Open-File Report 82-672, 58 p.

Huffman, C. A., and (7) others, 1981 (1982), Measured sections of the Cretaceous Nanushuk Group undivided, western North Slope, Alaska: U.S. Geological Survey Open-File Report 81-176. [Available on microfilm only, with Open-File Report 81-177.]

Jones, D. L., Silberling, N. J., Gilbert, W. G., and Coney, P. J., 1983, Tectonostratigraphic map and interpretive bedrock geological map of the Mount McKinley region, Alaska: U.S. Geological Survey Open-File Report 83-11, 2 sheets.

King, H. D., Sutley, S. J., and McDougal, C. M., 1982, Analytical data for the minus-80-mesh stream-sediment samples collected during 1981 from the Solomon and Bendeleben quadrangles, Alaska: U.S. Geological Survey Open-File Report 82-964, 46 p., 2 sheets, scale 1:250,000.

Kowalik, W. S., 1982, The use of Landsat data in exploration for limonitic outcrops in the Circle quadrangle, Alaska: U.S. Geological Survey Open-File Report 82-529, 14 p. 
Lachenbruch, A. H., Sass, J. H., Lawver, L. A., Brewer, M. C., and Moses, T. H., Jr., 1982, Depth and temperature of permafrost on the Alaska Arctic Slope-Preliminary results: U.S. Geological Survey Open-File Report 82-1039, 30 p.

Mayfield, C. F., Curtis, S. M., Ellersieck, Inyo, and Tailleur, I. L., 1982, Reconnaissance geologic map of southeastern Misheguk Mountain quadrangle, Alaska: U.S. Geological Survey OpenFile Report 82-613, 40 p., 2 oversize sheets, scale 1:250,000.

Miller, R. J., Winkler, G. R., O'Leary, R. M., and Cooley, E. F., 1982, Analyses of rock, stream-sediment, and heavy-mineral concentrate samples from the Valdez quadrangle, Alaska: U.S. Geological Survey Open-File Report 82-451, 225 p., 2 sheets, scale 1:250,000.

Morrone, J. F., compiler, 1982, Bibliography of Alaskan geologic maps by 1:250,000 quadrangle: U.S. Geological Survey OpenFile Report 82-195, $70 \mathrm{p}$.

Nilsen, T. H., and Moore, T. E., 1982, Sedimentology and stratigraphy of the Kanayut Conglomerate, central and western Brooks Range, Alaska-Report of the 1981 field season: U.S. Geological Survey Open-File Report 82-674, 68 p.

Nilsen, T. H., Moore, T. E., Balin, D. F., and Johnson, S. Y., 1982, Sedimentology and stratigraphy of the Kanayut Conglomerate, central Brooks Range, Alaska: U.S. Geological Survey Open-File Report 82-199, 85 p.

Nokleberg, W. J., Albert, N. R. D., Bond, G. C., Herzon, P. L., Miyaoka, R. T., Nelson, W. H., Richter, D. H., Smith, T. E., Stout, J. H., Yeend, Warren, and Zehner, R. E., 1982, Geologic of the southern part of the Mt. Hayes quadrangle, Alaska: U.S. Geological Survey Open-File Report 82-52, 1 sheet, scale 1:250,000.

O'Leary, R. M., Risoli, D. A., Curtin, G. C., Tripp, R. B., McDougal, C. M., and Huston, D. L., 1982, Final analytical results of stream-sediment, glacial debris, and nonmagnetic heavy-mineral concentrate samples from the Mt. Hayes quadrangle, Alaska: U.S. Geological Survey Open-File Report 82-325, 130 p., 1 oversize sheet, scale 1:250,000.

Patton, W. W., Jr., Cady, J. W., and Moll, E. J., 1982, Aeromagnetic interpretation of the Medfra quadrangle, Alaska: U.S. Geological Survey Open-File Report 82-811-E, 15 p., 2 sheets, scale $1: 250,000$.

Payne, T. G., 1982, Use of microcomputer in mapping depth of stratigraphic horizons in National Petroleum Reserve in Alaska: U.S. Geological Survey Open-File Report 82-1054, $42 \mathrm{p}$.

Reimnitz, Erk, Barnes, P. W., Rearic, D. M., Minkler, P. W., and Kempema, E. W., 1982, Marine geological investigations in the Beaufort Sea in 1981, and preliminary interpretations for regions from the Canning River to the Canadian border: U.S. Geological Open-File Report 82-794, 64 p.

Silberling, N. J., Richter, D. H., Jones, D. L., and Coney, P. J., 1982, Geologic map of the bedrock of part of the Healy A-1 quadrangle south of the Talkeetna-Broxon Gulch fault system, Clearwater Mountains, Alaska: U.S. Geological Survey Open-File Report 81-1288, 1 sheet, scale 1:63,360.

Trautwein, C. M., Greenlee, D. D., and Orr, D. G., 1982, Digital data base application to porphyry copper mineralization in Alaska-Case study summary: U.S. Geological Survey OpenFile Report 82-801, 14 p.

Varnes, K. L., Charpentier, R. R., and Dolton, G. L., 1982, Conditional estimates and marginal probabilities for undiscovered recoverable oil and gas resources by province-Statistical background data for U.S. Geological Survey Circular 860: U.S. Geological Survey Open-File Report 82-666A, 30 p.
1982, Estimates of undiscovered recoverable resources of total gas by province-Statistical background for U.S. Geological Survey Circular 860: U.S. Geological Survey OpenFile Report 82-666D, $18 \mathrm{p}$.

Varnes, K. L., and Dolton, G. L., 1982, Estimates of Federal ownership of undiscovered oil and gas resources by provinceStatistical background data for U.S. Geological Survey Circular 860: U.S. Geological Survey Open-File Report 82-666B, $15 \mathrm{p}$.

1982, Estimated areas and volumes of sedimentary rock in the United States by province-Statistical background data for U.S. Geological Survey Circular 860: U.S. Geological Survey Open-File Report 82-666-C, 12 p.

Williams, J. R., 1982, Design review, Trans-Alaska Oil Pipeline, 1974-1976: U.S. Geological Survey Open-File Report 82-225, $140 \mathrm{p}$.

Wilson, F. H., 1982, Maps and tables showing preliminary results of $\mathrm{K}-\mathrm{Ar}$ age studies in the Ugashik quadrangle, Alaska Peninsula: U.S. Geological Survey Open-File Report 82-140, 1 sheet.

\section{Miscellaneous Field Studies Maps}

Cathrall, J. B., Billings, T. M., Cooley, E. F., and O'Leary, R. M., 1981 [1982], Map showing anomalous drainage areas of selected elements in the Survey Pass quadrangle, Brooks Range, Alaska: U.S. Geological Survey Miscellaneous Field Studies Map MF-1176-D, 1 sheet.

Cady, J. W., and Hackett, S. W., 1982, Maps showing aeromagnetic survey and interpretation of the Survey Pass quadrangle, Brooks Range, Alaska: U.S. Geological Survey Miscellaneous Field Studies Map MF-1176-G, 13 p., 3 sheets.

Cox, D. P., Detra, D. E., and Detterman, R. L., 1981, Mineral resources maps of the Chignik and Sutwik Island quadrangles, Alaska: U.S. Geological Survey Miscellaneous Field Studies Map MF-1053-K, 2 sheets.

Nelson, S. W., and Nelson, W. H., 1982, Geology of the Siniktanneyak Mountain ophiolite, Howard Pass quadrangle, Alaska: U.S. Geological Survey Miscellaneous Field Studies Map MF-1441, 1 sheet, scale 1:63,3600.

Tailleur, I. L., and Engwicht, S. E., 1983, Maps showing land status and well locations and tables of well data, eastern North Slope petroleum province, Alaska: U.S. Geological Survey Miscellaneous Field Studies Map MF-928-A, 5 sheets, scale 1:500,000.

Tysdal, R. G., and Case, J. E., 1982, Metalliferous mineral resource potential of the Seward and Blying Sound quadrangles, southern Alaska: U.S. Geological Survey Miscellaneous Field Studies Map MF-0761, 1 sheet.

\section{Circulars}

Berg, H. C., 1982, The Alaska Mineral Resource Assessment Program-Guide to information about the geology and mineral resources of the Ketchikan and Prince Rupert quadrangles, southeastern Alaska: U.S. Geological Survey Circular 855, 24 p. [Supersedes Open-File Report 80-794.]

Coonrad, W. L., ed., 1982, The United States Geological Survey in Alaska: Accomplishments during 1980: U.S. Geological Survey Circular 844,178 p. The following articles contain information pertinent to this report:

Aleinikoff, J. N., and others-Age, intrusion, and metamorphism of the East Susitna Batholith, Mount 
Hayes B-6 quadrangle, eastern Alaska Range, Alaska

Armstrong, A. K.-Petrography and cathode luminescence of carbonate rocks at Bornite, Alaska

Blanchard, D. C., and Tailleur, I. L.-Preliminary geothermal isograd map, NPRA

Carter, R. D., NPRA data release, 1980

Chapman, R. M., and others-Preliminary summary of the geology in the eastern part of the Ophir quadrangle

Decker, J. E., and Hoare, J. M.-Sedimentology of the Cretaceous Kuskokwim Group, southwest Alaska

Detra, D. E., and others-Reconnaissance geochemical studies in the Bristol Bay, Ugashik, and Karluk quadrangles, Alaska

Ellersieck, Inyo, and others-The Story Creek and Whoopee Creek lead-zinc-silver occurrences, western Brooks Range, Alaska

Evenson, E. B., and others-Geochemical exploration using englacial debris

Foster, H. L., and O'Leary, R. M., Gold found in bedrock of Lost Chicken gold placer mine

Frank, C. O., and Zimmerman, Jay-Petrography of nonultramafic rocks from the Avan Hills complex, DeLong Mountains, Alaska

Hessin, T. D.-Geochemical studies in the West Chichagof-Yakobi Wilderness

Hudson, Travais, and others-Horizontal of fset history of the Chatham Strait fault

Huffman, A. C., and others-Uranium investigations, northeast Alaska

Jones, D. L., and others-Tectonostratigraphic terrane map of Alaska

Karl, S. M., and others-Discrimination of Wrangellia and Chugach terrane in the Kelp Bay Group on Chichagof and Baranof Islands, southeastern Alaska

King, H. D.-Reconnaissance geochemical surveys of the Healy quadrangle

Molenaar, C. M., and others-Depositional facies and reservoir potential of the Fortress Mountain Formation, central North Slope

Molenaar, C. M., and others-Cretaceous-lower Tertiary depositional relations, northeastern Alaska

Moll, E. J., and Patton, W. W., Jr.-Preliminary report on the Late Cretaceous and early Tertiary volcanic and related plutonic rocks in western Alaska

Nilsen, T. H. and others-Significance of the Endicott Group for tectonic models of the Brooks Range

Nokleberg, W. J., and others-Geologic setting of the Maclaren metamorphic belt, Mt. Hayes A-6 and B-6 quadrangles, eastern Alaska Range

Patton, W. W., Jr., and Moll, E. J.-Structural and stratigraphic sections along a transect between the Alaska Range and Norton Sound

Tripp, R. B., Detra, D. E., and Nishi, J. M.-Mineralized zones in bedrock near Miller Creek, Circle quadrangle

Yeend, W. E.-Placers and placer mining

Zimmerman, Jay, and Frank, C. O.-Possible obduction related metamorphic rocks at the base of the ultramafic zone, Avan Hills complex, DeLong Mountains
Duffield, W. A., and Guffanti, Marianne, 1982, The Geothermal Research Program of the U.S. Geological Survey: U.S. Geological Survey Circular 862, 15 p.

Reed, K. M., ed., 1982, The U.S. Geological Survey in Alaska1982: U.S. Geological Survey Circular 867, 107 p.

U.S. Geological Survey, 1982, 1982 annual report on Alaska's mineral resources: U.S. Geological Survey Circular 884, 59 p. [Prepared in cooperation with the Bureau of Mines, the Bureau of Land Management, the Minerals Management Service, the U.S. Fish and Wildlife Service, the Department of Agriculture-Forest Service, and the Department of Energy.] 1982, U.S. Geological Survey activities, fiscal year 1981: U.S. Geological Survey Circular 875, 161 p.

\section{Geological Quadrangle Map}

Lowe, P. C., Richter, D. H., Smith, R. L., and Schmoll, H. R., 1982, Geologic map of the Nabesna B-5 quadrangle, Alaska: U.S. Geological Survey Geologic Quadrangle Map GQ-1566, 1 sheet.

Special

U.S. Geological Survey, 1981, Index to Landsat worldwide reference system (WRS): scale 1:10,000,000. Alaska on sheets 2 and 6.

\section{Reports by U.S. Geological Survey authors in non-Survey} publications

Affolter, R. H., and Stricker, G. D., 1982, Geochemistry of the Capps and Waterfall coal beds, Tyonek Formation, Capps coal field, Cook Inlet region, Alaska (abs.): American Association for the Advancement of Science and the American Geophysical Union Science Meeting, Fairbanks, September 1982, p. 90.

Barker, Fred, and Arth, J. G., 1982, "Central Gneiss Complex" of the Coast Range batholith-The roots of a high-K, calcalkaline arc? (abs. no. 04620) Geological Society of America, Abstracts with Programs, v. 14, no. 7, p. 439.

Barker, Fred, and Grantz, Arthur, 1982, Talkeetna Formation in the southeastern Talkeenta Mountains, southern Alaska-An early Jurassic andesitic intraoceanic island arc [abs.]: Geological Society of America Abstracts with Programs, v. 14, no. 4 , p. 147.

Barnes, D. F., Mayfield, C. F., Morin, R. L., and Brynn, Sean, 1982, Gravity measurements useful in the preliminary evaluation of the Nimiutuk barite deposit, Alaska: Economic Geology, v. 77, no. 1, p. 185-189.

Berg, H. C., and Clautice, K. H., 1982, Status of mineral resource information for the Annette Island Reserve, southeastern Alaska: U.S. Bureau of Indian Affairs Report BIA-84, 77 p.

Bolm, J. G., McCulloch, T. H., and Stewart, R. J., 1982, Diagenesis of sandstones in Lower Cook Inlet basin, Alaska, and its implications for Mesozoic petroleum plays [abs.]: Alaska Geological Society Symposium, 1982, Program with Abstracts, p. 8.

Churkin, Michael, Jr., Foster, H. L., Chapman, R. M., and Weber, F. R., 1982, Terranes and suture zones in east-central Alaska: Journal of Geophysical Research, v. 87, no. 5, p. 3718-3730.

Coney, P. J., 1981, Accretionary tectonics in western North America: Arizona Geological Society Digest, v. 14, 23-27. 
Csejtey, Béla, Jr., Cox, D. P., Evarts, R. C., Stricker, G. D., and Foster, H. L., 1982, The Cenozoic Denali fault system and the Cretaceous accretionary development of southern Alaska: Journal of Geophysical Research v. 87, no. 5, p. 3741-3754.

Czamanske, G. K., Haffty, Joseph, and Nabbs, S. W., 1982, Pt, $\mathrm{Pd}$, and $\mathrm{Rh}$ analyses and beneficiation of mineralized mafic rocks from the La Perouse layered gabbro, Alaska: Economic Geology, v. 76, no. 7, p. 2001-2011.

Detterman, R. L., 1982, Late Mesozoic and Tertiary stratigraphy for the Alaska Peninsula [abs.]: Alaska Geological Society Symposium, 1982, Program with Abstracts, p. 5.

Eittreim, Stephen, Grantz, Arthur, and Greenberg, Jonathan, 1982, Active geologic processes in Barrow Canyon, northeast Chukchi Sea: Marine Geology, v. 50, no. 1/2, p. 61-76.

Fisher, M. A., 1982, Petroleum geology of North Basin, Alaska: American Association of Petroleum Geologists Bulletin, v. 66 , no. 3., p. 286-301.

Fisher, M. A., Patton, W. W. Jr., and Holmes, M. L., 1982, Geology of Norton Basin and continental shelf beneath northwestern Bering Sea: American Association of Petroleum Geologists Bulletin, v. 66, no. 3, p. 255-285.

1982, Geology and petroleum potential of Alaska's Norton Basin area: Oil and Gas Journal, v. 80, no. 18, p. 343-370.

Gehrels, G. E., Saleeby, J. B., and Berg, H. C., 1982, Geologic framework of a pre-Middle Devonian meta-igneous complex, Annette Island, southeastern Alaska [abs.]: Geological Society of America Abstracts with Programs, v. 4, no. 4, p. 165.

Globerman, B. R., Coe, R. S., Hoare, J. A., and Decker, J. E., 1982, Paleomagnetism of Late Jurassic-Early Cretaceous volcaniclastic rocks of the Russian Mission region, southwestern Alaska [abs.]: Geological Society of America Abstracts with Programs, v. 14, no. 4, p. 166.

Grantz, Arthur, and (16) others, 1982, A continent-ocean transect (Corridor A-3) across central Alaska from the Pacific to the Arctic (abs. no. 11820): Geological Society of America Abstracts with Programs, v. 14 no. 7, p. 501.

Grantz, Arthur, Carlson, C., Jones, D. L., Plafker, G., Yorath, C. J., and Woodsworth, G. J., 1982, Development of the continental margin of North America from the Queen Charlotte Islands to the Culf of Alaska (abs. no. 05899): Geological Society of America, Abstracts with Programs, v. 14, no. 7, p. 501.

Harbert, W. P., Scholl, D. W., Mann, D., Vallier, T. L., and Stevenson, A. J., 1982, Geologic and tectonic history of Atka Basin, Aleutian Ridge [abs.]: EOS, Transactions of the American Geophysical Union, v. 63, no. 45, p. 1115.

Hillhouse, J. W., and Grommé, C. S., 1982, Limits to northward drift of the Paleocene Cantwell Formation central Alaska: Geology, v. 10, p. 552-556.

Himmelberg, G. R., and Loney, R. A., 1982, The La Perouse layered gabbro, southeastern Alaska-An example of multiple magma emplacement (abs. no. 07901): Geological Society of America, Abstracts with Programs, v. 14, no. 7, p. 515.

Hopkins, D. M., 1982, Abortive glaciations at high altitudes indicated by glaciomarine deposits, Gubik Formation, northern Alaska [abs. no. 07894]: Geological Society of America, Abstracts with Programs, v. 14, no. 7, p. 518.

Hudson, Travis, and Plafker, George, 1982, Paleogene metamorphism of an accretionary flysch terrane, eastern Gulf of Alaska: Geological Society of America Bulletin, v. 93, no. 12, p. $1280-1290$.
Jones, D. L., Cox, Allan, Coney, Peter, and Beck, Myrl, 1982, The growth of western North America: Scientific American, v. 247 , no. 5 , p. $70-84$.

Jones, D. L., and Silberling, N. J., 1982, Stratigraphic analysis of accreted terranes in the Cordillera of western North America (abs. no. 00284): Geological Society of America, Abstracts with Programs, v. 14, no. 7, p. 523.

1982, Mesozoic stratigraphy-the key to tectonic analysis of southern and central Alaska, in Leviton, A. E., and others, eds., Frontiers of geological exploration of western North America: San Francisco, Calif., American Association of Petroleum Geologists, Pacific Division, p. 139-153.

Jones, D. L., Silberling, N. J., and Coney, P. J., 1982, Timing of major accretionary events in Alaska [abs.]: EOS (American Geophysical Union Transactions), v. 63, no. 45, p. 913-914.

Jones, D. L., Silberling, N. J., Gilbert, Wyatt, and Coney, Peter, 1982, Character, distribution, and tectonic significance of accretionary terranes in the Central Alaska Range: Journal of Geophysical Research, v. 87, no. 5, p. 3709-3717.

Lachenbruch, A. H., Sass, J. H., Marshall, B. V., and Moses, T. H., Jr., 1982, Permafrost, heat flow, and the geothermal regime of Prudhoe Bay, Alaska: Journal of Geophysical Research, v. 87, no. B11, p. 9301-9316.

Magoon, L. B., and Claypool, G. E., 1981, Petroleum geology of the Cook Inlet Basin, Alaska-An exploration model: Tulsa, Okla., American Association of Petroleum Geologists Studies in Geology 12, p. 355-374.

1982, NPRA Inigok No. 1-Use of Lopatin's method to reconstruct thermal maturity: Pacific Petroleum Geologist Newsletter, Jan. 1982, p. 4-6.

Marlow, M. S., and Cooper, A. K., 1982, Hydrocarbon potential of sedimentary basins of the Bering Sea shelf [abs.]: Alaska Geological Society Symposium, Program with Abstracts, p. 12-14.

McLean, Hugh, 1982, Lithologic diversity of Paleogene strata in the Aleutian Islands-Insights into ensimatic-arc development [abs.]: Geological Society of America Abstracts with Programs, v. 14, no. 4, p. 214.

Molenaar, C. M., 1982, Depositional history and seismic stratigraphy of Lower Cretaceous rocks, National Petroleum Reserve, Alaska, and adjacent areas [abs.]: America Association of Petroleum Geologists Bulletin, v. 66, no. 5, p. 608.

Molenaar, C. M., Huffman, A. C., and Kirk, A. R., 1982, Cretaceous-Lower Tertiary depositional relations, northeast Alaska [abs.]: American Association of Petroleum Geologists Bulletin, v. 66, no. 5, p. 608.

Moore, T. E., and Nilsen, T. H., 1982, Fluvial sedimentology of the Upper Devonian and Lower Mississippian(?) Kanayut Conglomerate, Brooks Range, Alaska [abs.]: Geological Society of America, Abstracts with Program, v. 14, no. 4, p. 218.

Mull, C. G., Tailleur, I. L., Mayfield, C. F., Ellerseick, Inyo, and Curtis, S., 1982, New Upper Paleozoic and Lower Mesozoic stratigraphic units, central and western Brooks Range, Alaska: American Association of Petroleum Geologists Bulletin, v. 66, no. 3, p. 348-362.

Nokleberg, W. J., Berg, H. C., Lange, I. M., Grybeck, Donald, and Jones, D. L., 1982, Relation of metallogenesis to accereted tectono-stratigraphic terranes in Alaska [abs]: American Association of Petroleum Geologists Bulletin, v. 66 , no. 5 , p. 979.

Patton, W. W., Jr., and Gilbert, W. G., 1982, Tectonics of westcentral Alaska and the adjoining Bering Sea region [abs.]: 
Alaska Geological Society Symposium, 1982, Program with Abstracts, p. 35.

Payne, T. G., 1982, Use of Apple II in mapping geology of coastal plain of NPR Alaska [abs.]: American Association of Petroleum Geologists Bulletin, v. 66, no. 10, p. 1706.

Pickthorn, W. J., 1982, Stable isotope and fluid inclusion study of the Port Valdez gold district, southern Alaska: Los Angeles, University of California, M. Sc. thesis, 66 p., 6 sheets.

Plafker, George, and Bruns, T. R., 1982, Late Cenozoic subduction-rather than accretion-at the eastern end of the Aleutian Arc (abs. no. 08818): Geological Society of America, Abstracts with Programs, v. 14, no. 7, p. 569.

Plafker, George, Bruns, T. R., Winkler, G. R., and Tysdal, R. G., 1982, Cross section of the eastern Aleutian Arc, from Mt. Spurr to the Aleutian Trench near Middleton Island, Alaska: Geological of America, Map and Chart Series MC-28P, 1 sheet.

Reed, B. L., Miesch, A. T., and Lanphere, M. A., 1982, Jurassic magmatic arc in the Alaska-Aleutian Range batholithChemical variations and polarity [abs.]: Alaska Geological Society Symposium, 1982, Program with Abstracts, p. 5-6.

1982, Plutonic rocks of Jurassic age in the Alaska-Aleutian Range batholith-Chemical variations and polarity [abs.]: Geological Society of American Abstracts with Programs, v. 14, no. 4, p. 226-227.

Scholl, D. W., and (9) others, 1982, The Aleutian-Bering shelf transect A-1 (abs. no. 11814): Geological Society of America, Abstracts with Programs, v. 14, no. 7, p. 611.

Scholl, D. W., and Vallier, T. L., 1982, Two-stage igneous, structural, and sedimentary evolution of the Aleutian RidgeImplications for petroleum and mineral resources [abs.]: Alaska Geological Society Symposium, 1982, Program with Abstracts, p. 14-15.

Scholl, D. W., von Huene R., and Grantz, A., 1982, Alaska geodynamiks (abs. no. 00454): Geological Society of America, Abstracts with Programs, v. 14, no. 7, p. 611.

Sweeney, J. F., Balkwill, H. R., Grantz, A., May, S. D., Mayr, U., and Sobczak, L. W., 1982, The continental margin of North America in the Canada Basin of the Arctic Ocean (abs. no. 11819): Geological Society of America, Abstracts with Programs, v. 14, no. 7, p. 628.

Tailleur, I. L., 1982, Minimum radiometric age for Norian rocks, Late Triassic, northern Alaska, in Odin, G. S., ed., Numerical dating in stratigraphy, Pt. II: New York, Wiley, p. 934-938.

von Huene, R., Detterman, R. L., Fisher, M., Moore, J. C., and Pulpan, H., 1982 Aleutian arc-trench system from the Kodiak shelf to the Kuskokwim Mountains, Alaska-Transect A-2 (abs. no. 11815): Geological Society of America, Abstracts with Programs, v. 14, no. 7, p. 639.

Westgate J. A., Péwé, T. L., and Gorton, M. P., 1982, Tephrochronology of the Gold Hill Loess in central Alaska (abs. no. 01710): Geological Society of America, Abstracts with Programs, v. 14 , no. 7 , p. 645-646.

[Note: EOS (American Geophysical Union Transactions), v. 63, no. 45 contains numerous articles about tectonics in Alaska.]

\section{BUREAU OF MINES}

\section{Mineral Land Assessment Reports (MLA)}

Fechner, S. A., and Meyer, M. P., 1982, Placer sampling and related Bureau of Mines activities in the Sound study area of the Chugach National Forest, Alaska: U.S. Bureau of Mines MLA 62-82, $23 \mathrm{p}$.

Jansons, Uldis, 1982, Cobalt content in samples from the Omar Copper Prospect, Baird Mountains, Alaska: U.S. Bureau of Mines MLA 109-82, 18 p.

1982, Zinc-lead occurrences in and near the National Petroleum Reserve in Alaska: U.S. Bureau of Mines MLA 121-82, $55 \mathrm{p}$.

Kimball, A. L., 1982, Mineral land assessment of Yakobi Island and adjacent parts of Chichagof Island, southeastern Alaska: U.S. Bureau of Mines MLA 97-82, 199 p., 11 pls.

Kurtak, J. M., 1982, A manganese occurrence on Chenega Island, Prince William Sound, Alaska: U.S. Bureau of Mines MLA 124-82, 9 p.

\section{Information Circulars}

Bureau of Mines staff, 1982, Analyses of natural gases, 1917-1980A compilation of all samples of natural gas taken in those years: U.S. Bureau of Mines Information Circular 8870 [section about Alaska on p. 8-14].

Bureau of Mines, Albany Research Center, 1983, Podiform chromite occurrences in the Caribou Mountain and lower Kanuti River areas, central Alaska, Part II, Beneficiation: U.S. Bureau of Mines Information Circular 8916 (in press as of March 20).

Foley, J. Y., and McDermott, M. M., 1983, Podiform chromite occurrences in the Caribou Mountain and lower Kanuti River areas, central Alaska, Part I, Reconnaissance investigations: U.S. Bureau of Mines Information Circular IC 8915 (in press as of March 20).

\section{Cooperative publications}

Berg, H. C., and Clautice, K. H., 1982, Status of mineral resource information for the Annette Islands Reserve, southeastern Alaska: [Prepared for the U.S. Bureau of Indian Affairs] Bureau of Indian Affairs BIA-84 Administrative Report, 77 p.

University of Alaska, Arctic Environmental Information and Data Center, 1982, Mineral terranes of Alaska: Special Report, Map Folio Series, 7 maps [available from the publisher in Anchorage].

\section{Reports by Bureau of Mines authors in non-Bureau publications}

Fechner, S. A., and Meyer, M. P., 1982, Bureau of Mines studies, forest appraisal, part of RARE II program, in The Alaska Miner, the Journal of the Alaska Miners Association, v. 10, no. 5, p. 13-18.

Foley, J. Y., 1982, Alkaline igneous rocks in the eastern Alaska Range, in Short Notes on Alaskan Geology, 1981: Alaska Division of Geological and Geophysical Surveys Geological Report 73, p. 1-5.

Mulligan, J. J., 1982, Coals in Alaska: Society of Mining Engineers, American Institute of Mining Engineers Preprint 82-412, 4 p.

Pittman, T. L., and Mulligan, J. J., 1983, Alaska mining in '83From gold to hardrock and gravel: Alaska Construction and Oil, v. 24, no. 1, p. 21-23.

\section{U.S. FISH AND WILDLIFE SERVICE}

Elliott, G. V., 1982, Final report on the evaluation of stream crossing and the effects of channel modifications on fisheries 
resources along the Trans-Alaska Pipeline System: U.S. Department of the Interior, Fish and Wildlife Service Special Studies, Region 7, Anchorage, 110 p.

1982, Final report on fishery surveys along Northwest Alaska Pipeline Company's proposed gas pipeline routeDelta Junction to the Canadian border: U.S. Department of the Interior, Fish and Wildlife Service, Special Studies, Region 7, Anchorage, 127 p.

Hanley, P. T., and others, 1981 [1982], Natural resource protection and petroleum development in Alaska: U.S. Department of the Interior, Fish and Wildlife Service, FWS/OBS-80/22, $305 \mathrm{p}$.

1981 [1982], Natural resource protection and petroleum development in Alaska-A summary: U.S. Department of the Interior, Fish and Wildlife Service, FWS/OBS-80/22.1, 39 p.

1981 [1982], Natural resource protection and petroleum development in Alaska: U.S. Department of Interior, Fish and Wildlife Service, FWS/OBS-80/22.2, slide and tape presentation. [Available from U.S. Fish and Wildlife Service, Anchorage, Alaska.]

1982, A handbook for management of oil and gas activities on lands in Alaska: U.S. Department of Interior, Fish and Wildlife Service, FWS/OBS-80/23 [in press as of Jan. 1983].

Longley, W. L., Jackson R., and Snyder, B., 1982, Managing oil and gas activities in coastal environments-Comprehensive report: U.S. Department of the Interior, Fish and Wildlife Service, FWS/OBS-82/02, 839 p. [Not specific to Alaska, but contains applicable information; discusses existing regulations and guidelines.]

U.S. Fish and Wildlife Service, 1982, Arctic National Wildlife Refuge coastal plain assessment-Initial report, baseline study of the fish, wildlife and their habitats: Region 7, Anchorage, 507 p. [Prepared in response to Section 1022(c) of ANILCA; describes potential impacts of geophysical exploration and development and production of oil and gas resources.]

1982, Draft environmental impact statement and draft regulations-Proposed oil and gas exploration within the coastal plain of the Arctic National Wildlife Refuge, Alaska: U.S. Department of the Interior, Fish and Wildlife Service, Geological Survey and Minerals Management Service, Anchorage, $375 \mathrm{p}$. [Prepared in response to Section 1022 of ANILCA and to National Environmental Policy Act of 1969.]

1983, Kenai National Wildlife Refuge-Draft comprehensive conservation plan and environmental impact statement: U.S. Department of Interior, Fish and Wildlife Service (in press). [Prepared in response to Section 304(g) and in partial fulfillment of Section 1008 of ANILCA.]

\section{BUREAU OF LAND MANAGEMENT}

U.S. Bureau of Land Management, 1982, Draft environmental impact statement on oil and gas leasing and development in the National Petroleum Reserve in Alaska: Anchorage, Alaska, 111 p.

1982, Federal North Slope land studies for the Central Arctic Area of Alaska-Annual report, fiscal year 1982 [under Title X, Section 1001, ANILCA]: 14 p. [Available for inspection only at the Natural Resources Library, Federal Building, Anchorage.]

1982, Oil and gas leasing program for non-North Slope Federal lands in Alaska-Annual report, fiscal year 1982 [under Title X, Section 1008, ANILCA]: 8 p., 2 appendixes. [Available for inspection only at the Natural Resources Library, Federal Building, Anchorage.]

The following booklets about the National Petroleum Reserve in Alaska were released in 1982 and can be obtained from this agency:

Notice of Sale, Oil and Gas Lease Sale No. 821.

National Petroleum Reserve in Alaska Technical Examinationals TE-1-An Analysis of the type and likely level of NPR-A oil development(s).

Proceedings of the NPR-A caribou/waterbird impact analysis workshop (May 11-13, 1982).

Scoping document for future oil and gas leasing in NPR-A. Information packets-January, March, May 1982.

Energy Quarterly.

The following booklets about leases, special projects, and oil and gas industry meetings, as well as other pertinent documents, can be obtained through the Public Relations Office, Bureau of Land Management, Federal Building, Anchorage:

Federal land opening for mineral leasing and mineral entry. Office of Special Projects Annual Report 1982.

Government/Industry Alaska Oil and Gas Forum, March 31April 1, and October 27, 1982.

Noncompetitive oil and gas lease offering in AlaskaMinchumina.

\section{NATIONAL PARK SERVICE}

U.S. Department of the Interior, 1982, Environmental overview and analysis of mining effects-Yukon-Charley Rivers National Preserve: Denver, National Park Service, 98 p., maps.

\section{U.S. DEPARTMENT OF AGRICULTURE-FOREST SERVICE}

U.S. Forest Service, 1982, Final Environmental Impact StatementRoad access and bulk sampling at the U.S. Borax Quartz Hill molybdenum claims, Tongass National Forest, Alaska: U.S. Department of Agriculture, Alaska Region Report 165, 1 v.

1982, Appendix to the final Environmental Impact Statement-Road access and bulk sampling at the U.S. Borax Quartz Hill molybdenum claims, Tongass National Forest, Alaska: U.S. Department of Agriculture, Alaska Region Report 166, 1 v.

1982, Draft forest plan and Nellie Juan-College Fiord Wilderness study report, Chugach National Forest: 240 p.

1982, Draft environmental impact statement, Chugach National Forest Plan and Nellie Juan-College Fiord Wilderness study report: $270 \mathrm{p}$.

1982, Greens Creek draft environmental impact statement, Admiralty Island National Monument: Alaska Region Report 107 (in press).

\section{DEPARTMENT OF ENERGY}

[All reports are available from the Department of Energy, P.O. Box 2657, Grand Junction, CO 81502.]

Edgar, D. E., Onesti, L. J., and Kaszynski, G. M., 1982, Alaskan coal-Resources and development constraints: U.S. Depart- 
ment of Energy Report ANL/LRP 18. 131 p. [Land reclamation program, Argonne National Laboratory.]

U.S. Department of Energy, 1982, United States crude oil, natural gas, and natural gas liquid resources, 1981 annual report: U.S. Department of Energy, Energy Information Administration, Office of Oil and Gas, DOE/EIA-0219, 121 p.

\section{Published folios}

$\begin{array}{llll}\text { Quadrangle } & \text { Report number } & \text { Quadrangle } & \text { Report number } \\ \text { Black River } & \text { PGJ/F-108 } & \text { Lime Hills } & \text { PGJ/F-057 } \\ \text { Charley River } & \text { PGJ/F-106 } & \text { Mt. McKinley } & \text { PGJ/F-054 } \\ \text { Circle } & \text { PGJ/F-107 } & \text { Talkeenta } & \text { PGJ/F-058 } \\ \text { Coleen } & \text { PGJ } / \text { F-040 } & \text { Tyonek } & \text { PGJ/F-059 } \\ \text { Dixon Entrance } & \text { PGJ/F-047 } & & \end{array}$

Magnetic contour maps

$\begin{array}{llll}\text { Quadrangle } & \text { Report number } & \text { Quadrangle } & \text { Report number } \\ \text { Black River } & \text { GJM-041 } & \text { Naknek } & \text { GJM-022 } \\ \text { Candle } & \text { GJM-060 } & \text { Norton Bay } & \text { GJM-042 } \\ \text { Charley River } & \text { GJM-043 } & \text { Nulato } & \text { GJM-172 } \\ \text { Coleen } & \text { GJM-045 } & \text { Ruby } & \text { GJM-210 } \\ \text { Craig } & \text { GJM-044 } & \text { Russian Mission } & \text { GJM-028 } \\ \text { Fort Yukon } & \text { GJM-040 } & \text { Selawik } & \\ \text { Gulkana } & \text { GJM-063 } & \text { Seldovia } & \text { GJM-032 } \\ \text { Healy } & \text { GJM-062 } & \text { Shungnak } & \text { GJM-021 } \\ \text { Hughes } & \text { GJM-019 } & \text { Sleetmute } & \text { GJM-027 } \\ \text { Iditarod } & \text { GJM-061 } & \text { Sumdum } & \text { GJM-209 } \\ \text { Kantishna River } & \text { GJM-035 } & \text { Taylor Mountains } & \text { GJM-020 } \\ \text { Lime Hills } & \text { GJM-030 } & \text { Tyonek } & \text { GJM-029 } \\ \text { McGrath } & \text { GJM-171 } & \text { Unalakleet } & \text { GJM-034 } \\ \text { Nabesna } & \text { GJM-170 } & \text { Yakutat } & \text { GJM-208 } \\ & & \text { GJM-026 }\end{array}$

Hydrogeochemical and stream-sediment reconnaissance reports

\begin{tabular}{|c|c|c|c|}
\hline Quadrangle & Report number & Quadrangle & Report number \\
\hline Atlin & GJBX-17 & Mt. Michelson & GJBX-46 \\
\hline Barrow & GJBX-5 & Noatak & GJBX-180 \\
\hline Barter Island & GJBX-6 & Nulato & GJBX-36 \\
\hline Beechey Point & GJBX-7 & Ophir & GJBX-181 \\
\hline Bendeleben & GJBX-143 & Petersburg & GJBX-163 \\
\hline Bettles & GJBX-14 & Point Hope & GJBX-91 \\
\hline Big Delta & GJBX-13 & Point Lay & GJBX-152 \\
\hline Black River & GJBX-122 & Port Alexander & GJBX-153 \\
\hline Candle & GJBX-151 & Prince Rupert & GJBX-3 \\
\hline Chandler Lake & GJBX-49 & Ruby & GJBX-154 \\
\hline Charley River & GJBX-178 & Sagavanirktok & GJBX-155 \\
\hline Circle & GJBX-186 & Selawik & GJBX-139 \\
\hline Coleen & GJBX-12 & Seward & GJBX-140 \\
\hline Craig & GJBX-187 & Shishmaref & GJBX-141 \\
\hline DeLong Mountains & GJBX-159 & Shungnak & GJBX-142 \\
\hline Demarcation Point & GJBX-89 & Sitka & GJBX-128 \\
\hline Eagle & GJBX-189 & Saint Michael & GJBX-20 \\
\hline Flaxman Island & GJBX-160 & Sumdum & GJBX-47 \\
\hline Harrison Bay & GJBX-41 & Taku River & GJBX-126 \\
\hline Howard Pass & GJBX-8 & Talkeetna & GJBX-138 \\
\hline Iditarod & GJBX-185 & Talkeetna Mountains & GJBX-137 \\
\hline Ikpikpuk River & GJBX-161 & Tanana & GJBX-108 \\
\hline Juneau & GJBX-90 & Teller & GJBX-124 \\
\hline Kantishna & GJBX-188 & Teshekpuk & GJBX-93 \\
\hline Kateel River & GJBX-182 & Tyonek & GJBX-138 \\
\hline Killik River & GJBX-37 & Umiat & GJBX-94 \\
\hline Kotzebue & GJBX-179 & Unalakleet & GJBX-95 \\
\hline Livengood & GJBX-2 & Utukok River & GJBX-92 \\
\hline Lookout Ridge & GJBX-44 & Wainwright & GJBX-48 \\
\hline Meade River & GJBX-162 & & \\
\hline
\end{tabular}

$\begin{array}{ll}\text { Melozitna } & \text { GJBX-183 } \\ \text { Middleton Island } & \text { GJBX-18 } \\ \text { Mishguk Mountains } & \text { GJBX-19 } \\ \text { Mt. Fairweather } & \text { GJBX-45 } \\ \text { Mt. McKinley } & \text { GJBX-138 }\end{array}$

\section{Miscellaneous topics}

Three applications of hydrogeochemical and stream-sediment reconnaissance data interpretation for a selected region in south-central Alaska-GJBX-138

\section{MISCELLANEOUS FEDERAL PUBLICATIONS}

National Geophysical Data Center, 1982, NPRA Final Report1974-81: 3 vols.

\section{NON-FEDERAL PUBLICATIONS}

\section{General topics}

Alaska Department of Commerce and Economic Development, 1982, Alaska-Power, energy, and resources: Office of Special Industrial Products, Special Publication [booklet], $50 \mathrm{p}$.

Alaska Division of Geological and Geophysical Survey, .1982, Index map of DGGS publications: Information Circular 23, 26 p., 1 sheet.

1982, List of formal reports issued by the Alaska Division of Geological and Geophysical Surveys: Information Circular 11A, 34 p.

1982, List of open-file reports issued by the Alaska Division of Geological and Geophysical Surveys: Information Circular $11 \mathrm{~B}, 36 \mathrm{p}$.

Alaska Department of Natural Resources, 1982, FY83 statewide natural resources plan-Resource transportation options: media release October 22, 1982, 20 p., 1 sheet (scale $1: 2,500,000)$.

Alaska Geographic Society, 1982, Alaska's oil/gas and minerals industry: v. 9, no. 4, 216 p.

Berger and Associates, 1982, Summary report, western and Arctic Alaska transportation study: Alaska Department of Transportation, contract report, $57 \mathrm{p}$.

\section{Nonfuel, critical and strategic minerals}

Alaska Construction and Oil, 1982, Alaska mining-Bucking the recession: v. 23 , no. 9,63 p.

Bundtzen, T. K., 1982a, Overview of Alaska's strategic minerals, in International Minerals-A National Perspective: Washington, D.C., American Association for the Advancement of Science, Symposium, January 1982, 34 p.

$1982 \mathrm{~b}$, Bedrock geology of the Fairbanks mining district, west sector, Alaska: Alaska Division of Geological and Geophysical Surveys Open-File Report 155, 2 sheets, scale $1: 24,000$.

Bundtzen, T. K., Eakins, G. R., and Conwell, C. N., 1982, Review of Alaska's Mineral Resources: Alaska Department of Commerce and Economic Development, Special Publication, 52 p., 16 appendixes, and $4 \mathrm{pl}$.

Bundtzen, T. K., and Smith T. E., 1982, Alaska's industrial minerals, in Alaska's oil/gas minerals industry: Alaska Geographic, v. 9, no. 4, p. 64-73. 
1982, Industrial minerals in Alaska: Western Miner, v. 55, no. 11, p. 30-32.

1982, Alaska's industrial minerals examined: Alaska Prospector's and Miner's News, fall quarter.

Cohen, K. K., 1982, Independence mine and the Willow Creek mining district: Alaska Division of Natural Resources, Division of Parks, $169 \mathrm{p}$.

Conwell, C. N., 1982, Mineral preparation, Grant gold mine, Alaska: Alaska Division of Geophysical and Geophysical Surveys Geologic Report 74, 15 p.

Dillon, J. J., 1982, Source of lode and placer gold deposits of the Chandalar and upper Koyukuk districts, Alaska: Alaska Division of Geological and Geophysical Surveys Open-File Report 158,22 p., 1 sheet, scale 1:250,000.

Eakins, G. R., Bundtzen, T. K., Robinson, M. S., Clough, J. G., Green, C. B., Clautice, K. H., and Albanese, M. A., 1983, Alaska's mineral industry 1982: Alaska Division of Geological and Geophysical Surveys Special Report 31, 63 p.

Forbes, R. B., 1982, Bedrock geology and petrology of the Fairbanks mining district, Alaska: Alaska Division of Geological and Geophysical Surveys Open-File Report 168, 68 p.

Forbes, R. B., and Weber, F. R., 1982, Bedrock geologic map of the Fairbanks mining district: Alaska Division of Geological and Geophysical Surveys Open-File Report 170, 2 sheets, scale $1: 63,360$.

Hawkins, D. B., 1982, Gold content of rocks in the Fairbanks mining district, Alaska: Alaska Division of Geological and Geophysical Surveys Open-File Report 169, 103 p.

1982, Hierarchical analysis of variance of stream-sediment samples for geochemical reconnaissance, Ester Dome, Fairbanks mining district, Alaska: Alaska Division of Geological and Geophysical Surveys Open-File Report 167, 86 p.

Hitzman, M. W., Smith, T. E., and Proffett, J. M., 1982, Bedrock geology of the Ambler district, southwestern Brook Range, Alaska: Alaska Division of Geological and Geophysical Surveys Geologic Report 75, 2 sheets, scale 1:125,000.

Metz, P. A., 1982, Bedrock geology of the Fairbanks mining district, northeast sector, Alaska: Alaska Division of Geological and Geophysical Surveys Open-File Report, 1 sheet, scale $1: 24,000$.

Metz, P. A., and Campbell, B. W., 1982, Cost of exploration for metallic minerals in Alaska-1982: Fairbanks, University of Alaska, Minerals Industry Research Laboratory Report 56, $83 \mathrm{p}$.

Robinson, M. S., 1982, Bedrock geology of the Fairbanks mining district, southeast sector, Alaska: Alaska Division of Geological and Geophysical Surveys Open-File Report 146, 1 sheet, scale $1: 24,000$.

Robinson, M. S., and Bundtzen, T. K., 1982, Geology of the Scafford antimony-gold lode deposit, Fairbanks mining district, Alaska: Alaska Division of Geological and Geophysical Surveys Open-File Report 173, 7 p. and 1 pl.

Wescott, Gene, 1982, Evaluation of geophysical methods in the Fairbanks mining district: Alaska Division of Geological and Geophysical Surveys Open-File Report 171, 24 p.

[Note: The Alaska Division of Geological and Geophysical Surveys has released a series of maps that contain the complete history of mining claims activity in the following quadrangles: Eagle, DeLong Mountains, Phillip Smith Mountains, Chandalar, Tanana, Livengood, Charles River, Ruby, Mt. Hayes, and Talkeetna. Nearing completion are maps for the Circle, Fairbanks, and Big Delta quadrangles.] See also Alaska Geographic Society, under "Oil and gas."

\section{Coal and peat}

Antenucci, J. C., 1982, A bibliographic survey of socioeconomic and cultural information for Alaska's coal bearing areas: Frankfort, Ky., PlanGraphics Inc., 35 p.

Conwell, C. N., Triplehorn, D. M., and Ferrell, V. M., 1981, Coals of the Anchorage quadrangle, Alaska: Alaska Division of Geological and Geophysical Surveys Special Report 17, 8 p., 4 sheets.

Merrit, R. D., Eakins, G. R., and Clough, J. G., 1982, Coal investigations of the Susitna Lowlands, Alaska: Alaska Division of Geological and Geophysical Surveys Open-File Report 142, $75 \mathrm{p}$.

Solie, D. N., and Dickey, D. B., 1982, Coal occurrences and analyses, Farewell-White Mountain area, Alaska: Alaska Division of Geological and Geophysical Surveys Open-File Report 160, $17 \mathrm{p}$.

Triplehorn, D. M., 1982, Alaska coal-A bibliography: University of Alaska Mineral Industries, Research Laboratory Report 51, 298 p. [Current to May 1981.]

Oil and gas

Alaska Geographic Society, 1982, Alaska's oil/gas and minerals industry: Alaska Geographic, v. 9, no. 4, 216 p.

Bruynzeel, J. W., Guldenzopf, E. C., and Pickard, J. E., 1982, Petroleum exploration of NPRA, 1974-1981-Final Report: Houston, Texas, Tetra Tech Report 8200,3 vols., 5 boxes of geophysical maps. [Prepared for Husky Oil NPR Operations, Inc., Anchorage, under USGS-Husky contract 14-08-000116474, Husky Tetra Tech subcontract GC-81-5.3.]

Carman, G. J., and Hardwick, Peter, 1982, Geology and regional setting of the Kuparuk oil field: Oil and Gas Journal, v. 80, no. 47 , p. $153-158$.

Gutman, S. I., Goldstein, A., and Guldenzopf, E. C., 1982, Gravity and magnetic investigations of the National Petroleum Reserve in Alaska: Houston, Texas, Tetra Tech, Inc., Report 8202, 1 vol., 5 boxes of plates. [Prepared for Office of National Petroleum Reserve in Alaska under USGS contract 14-08-000120203.]

Lyle, W. M., Palmer, I. F., Jr., Bolm, J. G., and Flett, T. O., 1983, Hydrocarbon reservoir and source-rock characteristics from selected areas of southwestern Alaska: Alaska Division of Geological and Geophysical Surveys Professional Report 77, 15 p.

Oil and Gas Journal, 1982, Kuparuk to become second-largest oil field in U.S.: Oil and Gas Journal, v. 80, no. 28, p. 80-83.

1982, D\&M sees 900 million bbl for Alaska sale area: v. 80, no. 48 , p. 46.

1982, First Prudhoe Bay EOR project aims for start-up: v. 80 , no. 49 , p. $118-119$.

[Oil and Gas Journal, v. 80, nos. 39, 40, 42 contain articles on Alaskan oil fields and development.]

\section{Geothermal energy}

East, Jennifer, 1982, Preliminary geothermal investigations at Manley Hot Springs, Alaska: University of Alaska Report to U.S. Department of Energy under cooperative agreement DE-FC07-79-ET 27034, 76 p.

Motyka, R. J., Moorman, M. A., and Poreda, R., 1982, Fluid 
geochemistry of Hot Springs Bay valley, Akutan Island, Alaska, in Davis, Calif., Geothermal Research Council Transactions, v. 6, 1982, Geothermal Energy: Turn on the Power, p. 103-106.

1982, Fluid geochemistry of the Makushin geothermal area, Unalaska Island, Alaska, in Davis, Calif., Geothermal Research Council Transactions, v. 6, 1982, Geothermal Energy: Turn on the Power, p. 107-110.

Reeder, J. W., 1982, Hydrothermal resources of the northern part of Unalaska Island, Alaska: Alaska Division of Geological and Geophysical Surveys Special Open-File Report 163, $17 \mathrm{p}$.

Reeder, J. W., Economides, M. J., and Markle, D. R., 1982, Economic and engineering considerations for geothermal development in the Makushin Volcano region of Unalaska Island, Alaska, in Davis, Calif., Geothermal Research Coun- cil Transactions, v. 6, 1982, Geothermal Energy: Turn on the Power, p. 385-388.

Spencer, S. G., Long, G.A., and Chapman-Riggsbee, W., 1982, An analysis of geothermal resoarce development on Unalaska Island, Alaska, in Davis, Calif., Geothermal Research Council Transactions, v. 6, 1982, Geothermal Energy: Turn on the Power, p. 393-396.

Turner, D. L., and Forbes, R. B., eds., 1980, A geological and geophysical study of the geothermal energy potential of Pilgrim Springs, Alaska: University of Alaska, Geophysical Institute, Report UAG R-271, 165 p.

Turner, D. L., Wescott, E. M., Witte, William, and Petzinger, Becky, 1982, Geothermal energy resources of the lower Susitna Basin, Alaska, in Davis, Calif., Geothermal Research Council Transactions, v. 6, 1982, Geothermal Energy: Turn on the Power, p. 67-69. 